\title{
Isonitrile ruthenium and iron PNP complexes: Synthesis, characterization and catalytic assessment for base-free dehy- drogenative coupling of alcohols.
}

\author{
Duc Hanh Nguyen, ${ }^{\mathrm{a}}$ Delphine Merel, ${ }^{\mathrm{a}}$ Nicolas Merle, ${ }^{\mathrm{a}}$ Xavier Trivelli, ${ }^{\mathrm{b}}$ Frédéric Capet $^{\mathrm{a}}$ and Régis M. \\ Gauvin*,c \\ a Univ. Lille, CNRS, Centrale Lille, ENSCL, Univ. Artois, UMR 8181 - UCCS - Unité de Catalyse et Chimie du Solide, F- \\ 59000 Lille, France \\ ${ }^{\mathrm{b}}$ Université de Lille, CNRS, INRA, Centrale Lille Institute, Univ. Artois, FR 2638 - IMEC - Institut Michel-Eugène Che- \\ vreul, F-59000 Lille, France \\ ${ }^{\mathrm{c}}$ Chimie ParisTech, PSL University, CNRS, Institut de Recherche de Chimie Paris, 75005 Paris, France. \\ E-mail : regis.gauvin@chimieparistech.psl.eu
}

KEYWORDS. Dehydrogenation • ruthenium • iron • pincer ligands • isonitrile.

Supporting Information Placeholder

\begin{abstract}
Neutral and ionic ruthenium and iron aliphatic $\mathrm{PNP}^{\mathrm{H}}$-type pincer complexes $\left(\mathrm{PNP}^{\mathrm{H}}=\mathrm{NH}\left(\mathrm{CH}_{2} \mathrm{CH}_{2} \mathrm{P} i \mathrm{Pr}_{2}\right)_{2}\right)$ bearing benzyl, $n$ butyl or tert-butyl isocyanide ancillary ligands have been prepared and characterized. Reaction of $\left[\mathrm{RuCl}_{2}\left(\mathrm{PNP}^{\mathrm{H}}\right)\right]_{2} \mathrm{with}_{\text {one }}$ equivalent CN$\mathrm{R}$ per ruthenium center affords complexes $\left[\mathrm{Ru}\left(\mathrm{PNP}^{\mathrm{H}}\right) \mathrm{Cl}_{2}(\mathrm{CNR})\right](\mathrm{R}=$ benzyl, $\mathbf{1 a}, \mathrm{R}=n$-butyl, 1b, $\mathrm{R}=t$-butyl, 1c), with cationic $\left[\mathrm{Ru}\left(\mathrm{PNP}^{\mathrm{H}}\right)(\mathrm{Cl})(\mathrm{CNR})_{2}\right] \mathrm{Cl}$ 2a-c as side-products. Complexes 2a-c are selectively prepared upon reaction of $\left[\mathrm{RuCl}_{2}\left(\mathrm{PNP}^{\mathrm{H}}\right)\right]_{2}$ with 2 equivalents of isonitrile per ruthenium center. Dichloride species 1a-c react with excess $\mathrm{NaBH}_{4}$ to afford $\left[\mathrm{Ru}\left(\mathrm{PNP}{ }^{\mathrm{H}}\right)(\mathrm{H})(\mathrm{BH} 4)(\mathrm{CN}-\mathrm{R})\right] 3 \mathrm{3a-c}$, analogues to benchmark Takasago catalyst $\left[\mathrm{Ru}(\mathrm{PNP})(\mathrm{H})\left(\mathrm{BH}_{4}\right)(\mathrm{CO})\right]$. Reaction of $\mathbf{1 a - c}$ with a single equivalent of $\mathrm{NaBH}_{4}$ under protic conditions results in formation of hydrido chloride derivatives $\left[\mathrm{Ru}\left(\mathrm{PNP}^{\mathrm{H}}\right)(\mathrm{H})(\mathrm{Cl})(\mathrm{CN}-\mathrm{R})\right](\mathbf{4 a - c})$, from which 3a-c can be prepared upon reaction with excess $\mathrm{NaBH}_{4}$. Use of one equivalent of $\mathrm{NaHBEt}_{3}$ with $\mathbf{4 a}$ and $\mathbf{4 c}$ affords bishydrides $\left[\mathrm{Ru}\left(\mathrm{PNP}^{\mathrm{H}}\right)(\mathrm{H})_{2}(\mathrm{CN}-\mathrm{R})\right] \mathbf{5 a}$ and $\mathbf{5}$. In the case of bulkier $t$-butylisonitrile, two isomers were observed by NMR, with the PNP framework in either meridional or facial conformation. Depro-

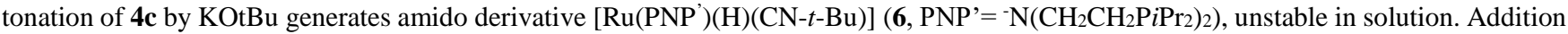
of excess benzylisonitrile to $\mathbf{4 a}$ provides cationic hydride $\left[\mathrm{Ru}\left(\mathrm{PNP}^{\mathrm{H}}\right)(\mathrm{H})\left(\mathrm{CN}_{-} \mathrm{CH}_{2} \mathrm{Ph}\right)_{2}\right] \mathrm{Cl}(\mathbf{7})$. Concerning iron chemistry, $\left[\mathrm{Fe}\left(\mathrm{PNP}^{\mathrm{H}}\right) \mathrm{Br}_{2}\right]$ reacts one equivalent benzylisonitrile to afford $\left[\mathrm{Fe}\left(\mathrm{PNP}^{\mathrm{H}}\right)(\mathrm{Br})\left(\mathrm{CNCH}_{2} \mathrm{Ph}\right)_{2}\right] \mathrm{Br}(\mathbf{8})$. The outer-sphere bromide anion can be exchanged by salt metathesis with $\mathrm{NaBPh}_{4}$ to generate $\left[\mathrm{Fe}\left(\mathrm{PNP}^{\mathrm{H}}\right)(\mathrm{Br})\left(\mathrm{CNCH}_{2} \mathrm{Ph}\right)_{2}\right]\left(\mathrm{BPh}_{4}\right)(\mathbf{9})$. Cationic hydride species $\left[\mathrm{Fe}(\mathrm{PNP})(\mathrm{H})(\mathrm{CN}-t-\mathrm{Bu})_{2}\right](\mathrm{BH} 4)(\mathbf{1 0})$ is prepared from consecutive addition of excess $\mathrm{CN}-t$ - Bu and $\mathrm{NaBH}_{4}$ on $\left[\mathrm{Fe}\left(\mathrm{PNP}^{\mathrm{H}}\right) \mathrm{Br}_{2}\right]$. Ruthenium complexes 3a-c are active in acceptorless alcohol dehydrogenative coupling into ester under base-free conditions. From kinetic follow-up, the trend in initial activity is $\mathbf{3 a} \approx \mathbf{3 b}>$ $\left[\mathrm{Ru}\left(\mathrm{PNP}^{\mathrm{H}}\right)(\mathrm{H})\left(\mathrm{BH}_{4}\right)(\mathrm{CO})\right] \gg>\mathbf{3 c}$; for robustness, $\left[\mathrm{Ru}(\mathrm{H})\left(\mathrm{BH}_{4}\right)(\mathrm{CO})\left(\mathrm{PNP}^{\mathrm{H}}\right)\right]>\mathbf{3 a}>\mathbf{3 b}>>\mathbf{3 c}$. Hypotheses are given to account for the observed deactivation. Complexes $3 \mathbf{b}, 3 \mathbf{c}, \mathbf{4 a}, \mathbf{4 c}, \mathbf{5 c}, \mathbf{7}$, cis $-\mathbf{8}$ and 9 were characterized by X-ray crystallography.
\end{abstract}

\section{Introduction}

Over the recent years, catalytic processes based on the acceptorless dehydrogenative coupling concept have blossomed, affording novel and efficient access to a cornucopia of value added products with high atom-economy and release of by-products such as water or hydrogen. Indeed, based on the metal-ligand cooperation concepts, new organometallic catalysts have been found to be active and selective in such transformations under very mild conditions. ${ }^{1}$ For example, transition metal complexes supported by bifunctional pincer ligand (along with ancillary monodentate ligands) have demonstrated impressive activity towards the (de)hydrogenation and related hydrogen borrowing reactions, ${ }^{2}$ thanks to pioneering works of Noyori ${ }^{3}$ and Milstein. ${ }^{4}$ Part of the efficiency of such systems stems from the relatively rigid meridional tridentate coordina- tion of the pincer ligand, which stabilizes the metal center and induces higher catalyst robustness even under demanding conditions (high temperature, basic conditions etc.). ${ }^{5}$

To date, a fair number of bifunctional pincer ligands bearing coordinating atoms such as phosphorous, ${ }^{6}$ nitrogen, ${ }^{7}$ sulfur ${ }^{8}$ and carbenic carbon ${ }^{9}$ has been designed, aiming at tuning both electronic and steric properties. ${ }^{5,10}$ In contrast, only little attention has been paid to ancillary monodentate ligands within the metal coordination sphere. ${ }^{11}$ As a matter of fact, $\mathrm{CO}$ appears to be a privileged ligand in this context, being involved in some of the most successful catalyst examples. It may be introduced from the starting carbonyl organometallic compound, or can be generated by decarbonylation reaction of alcohol under basic (catalytic) conditions. Interestingly, Gusev reported a series of complexes of general formula $\left[\mathrm{Ru}(\mathrm{Cl})_{2}(\mathrm{~L})\left(\mathrm{NH}\left(\mathrm{CH}_{2} \mathrm{CH}_{2} \mathrm{SEt}\right)_{2}\right)\right]\left(\mathrm{L}=\mathrm{CO}, \mathrm{PPh}_{3}\right.$ and $\left.\mathrm{AsPh}_{3}\right)$ and 
found that among them, the complex bearing $\mathrm{PPh}_{3}$ as ancillary ligand is the most active one for ester hydrogenation. ${ }^{8}$ Ogaka and Tayaki from Takasago Company replaced the carbonyl ligand within $\mathrm{Ru}-\mathrm{MACHO}\left[\mathrm{Ru}(\mathrm{X})(\mathrm{Cl})(\mathrm{L})\left(\mathrm{PNP}^{\mathrm{H}}\right)\right]\left(\mathrm{X}=\mathrm{H}, \mathrm{Cl}, \mathrm{PNP}^{\mathrm{H}}=\right.$ $\left.\mathrm{NH}\left\{\mathrm{CH}_{2} \mathrm{CH}_{2} \mathrm{P}(i \mathrm{Pr})_{2}\right\}_{2}\right)$ complexes by a $\sigma$-donor monodentate $\mathrm{N}$ heterocyclic carbene ligand, thus allowing ester reduction under atmospheric hydrogen pressure. ${ }^{12}$ On the other hand, very recently, Bernskoetter and Hazari have reported iron isonitrile PNP complexes, catalytically active for $\mathrm{CO}_{2}$ hydrogenation to formate, though being less active than the analogous carbonyl derivative. ${ }^{13}$ In the related field of carbonyl hydrogenation, both Reiser and Mezetti demonstrated the interest of using isonitrile ligands to achieve efficient iron-based catalysis. ${ }^{14}$ Indeed, even if the catalytic transformations involving metal-isonitrile species are less studied than those of isoelectronic metal-carbonyl counterparts, some advantages can be gained by the use of CNR-based catalysts ${ }^{15}:$ i) isonitrile is considered to be better electron donors and softer than $\mathrm{CO}$, and consequently improves their ability to interact effectively with both high- and low oxidation state metal centers; ii) R groups on the CNRs allow for broad variation of their steric properties and of the strength of the $\mathrm{M}-\mathrm{C}$ bonds; iii) similarly to carbonyl ligands, isonitrile ligands have distinctive IR and NMR signatures that contribute to both characterization and mechanistic studies.

As part of our ongoing program on structural and catalytic investigations around base-free dehydrogenative coupling reaction of alcohols, ${ }^{16}$ we investigated the synthesis of ruthenium and iron PNP supported complexes bearing isonitriles as ancillary ligand. These new isonitrile complexes were further catalytically assessed for base-free dehydrogenation reactions.

\section{Results and Discussion}

Dropwise addition of an isonitrile R-NC ( $\mathbf{a}: \mathrm{R}=\mathrm{CH}_{2} \mathrm{Ph}, \mathbf{b}: \mathrm{R}=n$ $\mathrm{Bu}$, c: $t$-Bu, $1.02-1.05$ equiv. vs. $\mathrm{Ru}$ ) THF solution to a suspension of Schneider's dimeric $\left[\mathrm{RuCl}(\mu-\mathrm{Cl})\left(\mathrm{PNP}^{\mathrm{H}}\right)\right]_{2}$ complex $^{17}$ in THF afforded ruthenium isonitrile adducts $\left[\mathrm{RuCl}_{2}(\mathrm{CN}-\mathrm{R})\left(\mathrm{PNP}^{\mathrm{H}}\right)\right] \mathbf{1 a - c}$ (Scheme 1). These complexes were formed along with small amount of cationic bis-isonitrile $\left[\mathrm{Ru}(\mathrm{Cl})(\mathrm{CN}-\mathrm{R})_{2}\left(\mathrm{PNP}^{\mathrm{H}}\right)\right](\mathrm{Cl}) \mathrm{com}$ plexes 2a-c (1-5\% from ${ }^{31} \mathrm{P}$ NMR). Since $\left[\mathrm{RuCl}_{2}(\mathrm{CN}-\mathrm{R})\left(\mathrm{PNP}^{\mathrm{H}}\right)\right]$ 1a-c are less soluble in $\mathrm{CH}_{2} \mathrm{Cl}_{2}$ than both their ionic 2a-c counterparts and the starting dimeric compound, their separation from the crude reaction mixture can be achieved by washing with $\mathrm{CH}_{2} \mathrm{Cl}_{2}$ at low temperature $\left(-5-0^{\circ} \mathrm{C}\right)$, with isolated yield ranging between 78 and $85 \%$. Under similar conditions, performing the reaction in $\mathrm{CH}_{2} \mathrm{Cl}_{2}$ (in which both Schneider's dimer and 2a-c are soluble) produced 1a-c in a less selective manner, as higher amounts of 2a-c were formed (up to $20 \%$ from ${ }^{31} \mathrm{P}$ NMR). This is likely due to a competitive side-reaction of 1a-c with isonitrile to form $\mathbf{2 a - c}$ under such conditions. Indeed, complexes 2a-c were prepared in good isolated yield (69-75\%) by reaction of Schneider's complex or of 1a-c with excess isonitrile, followed by crystallization in $\mathrm{CH}_{2} \mathrm{Cl}_{2} / \mathrm{Et}_{2} \mathrm{O}$ at $-20^{\circ} \mathrm{C}$. Both 1a-c and 2a-c series were characterized by multinuclear NMR $\left({ }^{1} \mathrm{H},{ }^{31} \mathrm{P},{ }^{13} \mathrm{C},{ }^{15} \mathrm{~N}\right)$ and IR spectroscopies and elemental analyses. Regarding species 1a-c, the ${ }^{31} \mathrm{P}$ NMR chemical shift of the PNP ligand of about $42 \mathrm{ppm}$ is reminiscent of that of the $\mathrm{PMe}_{3}$ adduct $(41 \mathrm{ppm})^{18}$. On the other hand, Bianchini, Peruzzini and coworkers reported the related isonitrile ruthenium complexes $\left.\quad\left[\mathrm{RuCl}_{2}\right)\left(\mathrm{CN}-\mathrm{R}^{\prime}\right)\left(\mathrm{PNP}^{n \mathrm{Pr}}\right)\right] \quad\left(\mathrm{PNP}^{n \mathrm{Pr}}=n \mathrm{Pr}-\right.$ $\left.\mathrm{N}\left(\mathrm{CH}_{2} \mathrm{CH}_{2} \mathrm{PPh}_{2}\right)_{2}\right),{ }^{19}$ in which the less bulky Ph-substituted PNP ligand adopts a facial type coordination mode. These give rise to ${ }^{31} \mathrm{P}$ NMR signals at about $58 \mathrm{ppm}$. Bearing in mind that within the complexes of the isopropyl-substituted ligand ${ }^{31} \mathrm{P}$ NMR chemical shifts are about $20 \mathrm{ppm}$ higher than those of the phenyl substituted ligand complexes, ${ }^{16 a}$ the values observed for $\mathbf{1 a - c}$ are in line with a meridional coordination of the PNP ligand. Even if no single crystal was obtained for 1a-c with quality allowing diffraction studies with publishable-grade data, we succeeded in recording diffraction patterns for the 1a complex. The overall coordination sphere could be assessed, as depicted on Figure 1. In this case, the PNP framework is indeed in meridional configuration, the chloride ligands are located in mutually trans positions, and the isonitrile ligand is in the cis position compared to the ruthenium-bound amino moiety. This contrasts with previous observations on related complexes, where the ancillary ligand in $\left[\mathrm{RuCl}_{2}\left(\mathrm{PNP}^{\mathrm{R}}\right)(\mathrm{L})\right]$ is in trans position from the Ru-N function. $18^{20}$

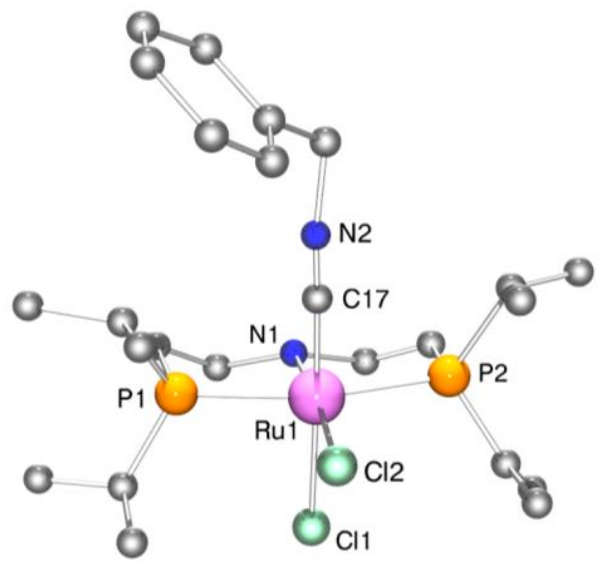

Figure 1. Connectivity scheme for 1a.

Within the 1a-c series, the presence of a N-H moiety was evidenced by the elongation vibration band at $3133-3148 \mathrm{~cm}^{-1}$ and by a triplet at 2.5-2.6 ppm on the ${ }^{1} \mathrm{H}$ NMR spectrum. Accordingly, $2 \mathrm{D}\left\{{ }^{1} \mathrm{H}-\right.$ ${ }^{15} \mathrm{~N}$ \} HSQC spectra of 1a-c display signal at about $19 \mathrm{ppm}$, which is in line with $\mathrm{sp}^{3}$ hybridization of the nitrogen center. Furthermore, the isonitrile ligands give rise to intense signals in the infrared spectrum at about $2100 \mathrm{~cm}^{-1}$. According to $\left\{{ }^{1} \mathrm{H}_{-}{ }^{15} \mathrm{~N}\right\}$ HMBC experiments, characteristic ${ }^{15} \mathrm{~N}$ NMR peaks assigned to the isonitrile function are observed in the 160-190 ppm range, thus being shifted highfield by $8-13$ ppm from the corresponding free isonitriles' signal. ${ }^{22}$ As a comparison, Bernskoetter and Hazari reported the analogous iron $\left[\mathrm{Fe}(\mathrm{Cl})_{2}(\mathrm{CN}-\mathrm{R})\left(\mathrm{PNP}^{\mathrm{H}}\right)\right]$, for which ${ }^{31} \mathrm{P}$ chemical shift and $\mathrm{C}-\mathrm{N}$ IR absorption values are of about $65 \mathrm{ppm}$ and $2050 \mathrm{~cm}^{-1}$, respectively. ${ }^{13}$

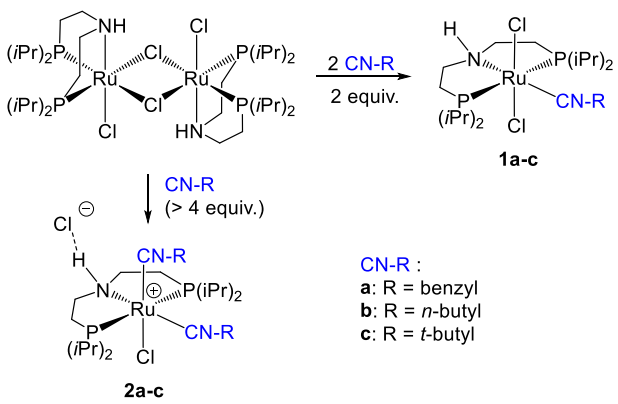

\section{Scheme 1. Syntheses of Ru PNPH chloride isonitrile adducts.}

The 2a-c species afford spectral characteristics in line with the proposed structure as cationic species. ${ }^{31} \mathrm{P}$ NMR chemical shifts are found around $49 \mathrm{ppm}$, which is about $7 \mathrm{ppm}$ higher than the values for 1a-c. As a comparison, the ${ }^{31} \mathrm{P}$ chemical shift of the bis-carbonyl $\left[\mathrm{RuCl}(\mathrm{CO})_{2}\left(\mathrm{PNP}^{\mathrm{H}}\right)\right]\left(\mathrm{BF}_{4}\right)$ derivative is of $49.8 \mathrm{ppm} .{ }^{21}$ The amino functionality spectroscopic features indicate that the chloride counter-anion interacts with the $\mathrm{N}-\mathrm{H}$ via H-bonding. Namely, the $v(\mathrm{~N}-$ $\mathrm{H}$ ) in $\mathbf{2 a}$ is found at about $70 \mathrm{~cm}^{-1}$ lower wavenumbers compared to that of 1a, while the ${ }^{1} \mathrm{H}$ chemical shift of $\mathrm{NH}$ within $\mathbf{2 a - c}$ is significantly low-field shifted by 4-5 ppm compared to that of 1a-c. In 
agreement with the presence of two inequivalent isonitrile ligands, the ${ }^{1} \mathrm{H}^{15} \mathrm{~N}$ HMBC spectrum of $\mathbf{2 a}-\mathbf{c}$ features two cross-signals in the $170-195 \mathrm{ppm}^{15} \mathrm{~N}$ chemical shift range. In the case of $\mathbf{2 a}$, on the 2D ${ }^{1} \mathrm{H}_{-}{ }^{13} \mathrm{C}$ HMBC spectrum, two cross-peaks are detected between the methylenic $\mathrm{N} \equiv \mathrm{C}-\mathrm{CH}_{2}$ protons and the isonitrile $\mathrm{N} \equiv \mathrm{C}$ carbon atoms (corresponding ${ }^{1} \mathrm{H} /{ }^{13} \mathrm{C}$ pairs: 5.15/153.5 ppm and 4.90/160.1 ppm). ${ }^{22}$

Treatment of 1a-c with excess $\mathrm{NaBH}_{4}$ (5-10 equiv.) in ethanol at room temperature led to the formation of borohydride complexes $\left[\mathrm{Ru}(\mathrm{H})\left(\mathrm{BH}_{4}\right)(\mathrm{RNC})\left(\mathrm{PNP}^{\mathrm{H}}\right)\right](\mathbf{3 a - c})$ in $\sim 70 \%$ isolated yield after crystallization from toluene/n-pentane at $-20^{\circ} \mathrm{C}$ (Scheme 2$)$. It is worth noting that the reaction of $\mathbf{1 c}$ with $\mathrm{NaBH}_{4}$ proceeds with lower rate than that of $\mathbf{1 a}$ and $\mathbf{1 b}$. In this case, a longer reaction time ( $48 \mathrm{~h}$ instead of $14 \mathrm{~h}$ ) is required to reach full conversion. This series of complexes displays spectroscopic properties similar to that of the related $\left[\mathrm{Ru}(\mathrm{H})\left(\mathrm{BH}_{4}\right)(\mathrm{CO})\left(\mathrm{PNP}^{\mathrm{H}}\right)\right]$ complex, with inter alia a ${ }^{31} \mathrm{P}$ NMR chemical shift of about $78 \mathrm{ppm}$, and $\mathrm{Ru}-\mathrm{H}$ resonating as a triplet centered at about $-15 \mathrm{ppm}$ (to be compared to $77.8 \mathrm{ppm}$ and $-13.5 \mathrm{ppm}$ for the carbonyl complex, respectively). The $\kappa^{1}-$ $\mathrm{HBH}_{3}$ ligand resonates as a broad signal centered at about $-1.5 \mathrm{ppm}$ which is indicative of a rapid exchange between the $\mathrm{BH}_{4}$ hydrogen atoms at room temperature. The presence of a N-H moiety was confirmed by both IR as well as ${ }^{1} \mathrm{H}$ and ${ }^{1} \mathrm{H}^{-15} \mathrm{~N}$ HSQC NMR. Noteworthy, from the two-dimensional ${ }^{1} \mathrm{H}-{ }^{1} \mathrm{H}$ NOE experiment (NOESY), a correlation between the $\mathrm{N}-\mathrm{H}$ and the $\mathrm{Ru}-\mathrm{HBH}_{3}$ peaks indicates a mutual syn-position of $\mathrm{NH}$ and $\mathrm{Ru}-\mathrm{HBH}_{3}$ moieties.

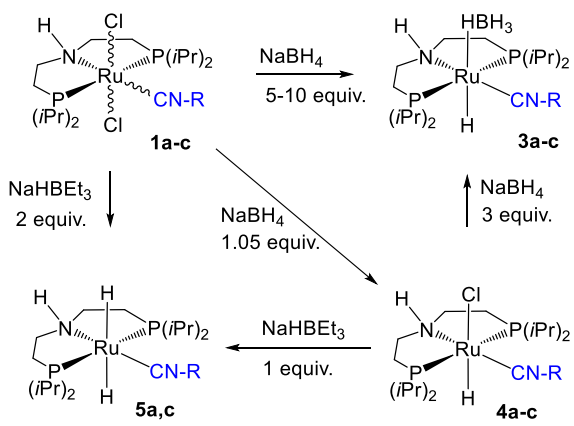

Scheme 2. General syntheses of $\mathrm{Ru} \mathrm{PNP}^{\mathrm{H}}$ hydride isonitrile complexes.

The solid-state structure of $\mathbf{3 b}$ and $\mathbf{3 c}$ was further determined by $\mathrm{X}$ ray diffraction studies (Figures 2 and 3). Both adopt similar configuration, namely distorted octahedral coordination sphere, with a PNP framework in meridional configuration, the isocyanide being in the trans-position to the amino group. The borohydride and hydride groups are located in syn- and anti-position compared to the $\mathrm{N}-\mathrm{H}$ bond, respectively. The isonitrile ligand adopts a no-liner configuration, as evidenced by the C17-N2-C18 angle (3b: 163.23(13), 3c: $\left.160.70(13)^{\circ}\right)$. It coordinates to the $\mathrm{Ru}(1)$ atom with a bond distance of 1.8944(10) and 1.8886(13) $\AA$ for 3b and 3c respectively, which is in the range of the $\mathrm{Ru}-\mathrm{C}$ (isonitrile) distances of known isonitrile complexes of ruthenium $(1.8-2.1 \AA) .{ }^{23}$ These complexes are isostructural to $\left[\mathrm{Ru}(\mathrm{H})\left(\mathrm{BH}_{4}\right)(\mathrm{CO})\left(\mathrm{PNP}^{\mathrm{H}}\right)\right],{ }^{16 \mathrm{a}}$ the carbonyl and isonitrile ligands occupying the same coordination site. The Ru1C17 bond distances of $\mathbf{3 b}$ and $\mathbf{3 c}$ are 1.8944(10) and 1.8886(13) Â, respectively that are longer than the $\mathrm{Ru}-\mathrm{C}$ bond distance $(1.8389(12) \AA)$ for $\left[\mathrm{Ru}(\mathrm{H})\left(\mathrm{BH}_{4}\right)(\mathrm{CO})\left(\mathrm{PNP}^{\mathrm{H}}\right)\right]$. This is in line with a higher $\pi$-accepting character of the carbonyl ligand with respect to that of isonitrile ligands. ${ }^{13}$

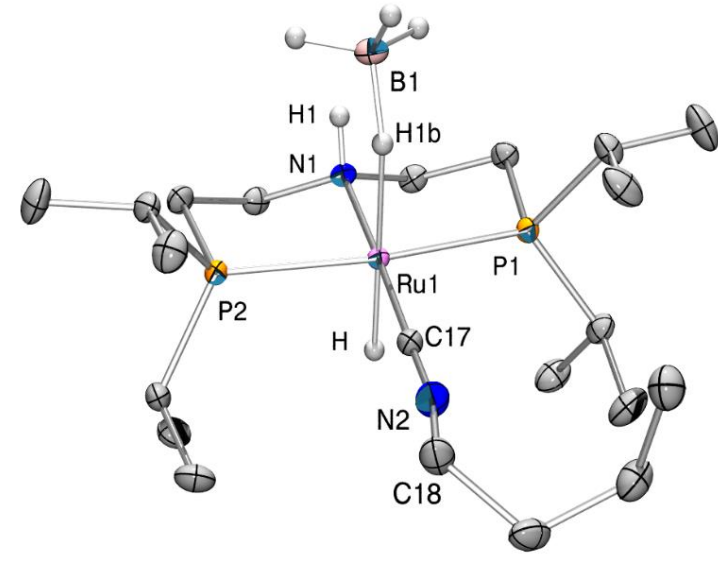

Figure 2. ORTEP view of solid-state structure of $\mathbf{3 b}$. All $\mathrm{H}$ atoms (except the $\mathrm{H}$ on $\mathrm{Ru}, \mathrm{B}$ and $\mathrm{N}$ ) are omitted for clarity. Selected bond distances $(\AA)$ : Ru1-P1 = 2.3092(3), Ru1-P2 = 2.3055(3), Ru1-N1 $=2.1884(9), \mathrm{Ru} 1-\mathrm{C} 17=1.8944(10), \mathrm{Ru} 1-\mathrm{H} 1 \mathrm{~B}=1.843(17), \mathrm{Ru} 1-$ $\mathrm{H}=1.507(17), \mathrm{N} 2-\mathrm{C} 17=1.1779$ (14). Selected angles (deg): P1$\mathrm{Ru} 1-\mathrm{H} 1 \mathrm{~B}=$ 91.6(5), $\mathrm{P} 1-\mathrm{Ru} 1-\mathrm{H}=89.7(6), \mathrm{P} 2-\mathrm{Ru} 1-\mathrm{P} 1=$ 165.054(10), P2-Ru1-H1B = 92.8(5), P2-Ru1-H = 86.4(6), N1$\mathrm{Ru} 1-\mathrm{P} 1=82.71(2), \mathrm{N} 1-\mathrm{Ru} 1-\mathrm{P} 2=82.76(2), \mathrm{N} 1-\mathrm{Ru} 1-\mathrm{H} 1 \mathrm{~B}=$ 93.8(5), N1-Ru1-H = 88.4(6), C17-Ru1-P1 = 97.69(3), C17-Ru1$\mathrm{P} 2=96.67(3), \mathrm{C} 17-\mathrm{Ru} 1-\mathrm{N} 1=177.36(4), \mathrm{C} 17-\mathrm{Ru} 1-\mathrm{H} 1 \mathrm{~B}=88.8(5)$, $\mathrm{C} 17-\mathrm{Ru} 1-\mathrm{H}=89.0(6), \mathrm{H} 1 \mathrm{~B}-\mathrm{Ru} 1-\mathrm{H}=177.6(8), \mathrm{C} 17-\mathrm{N} 2-\mathrm{C} 18=$ 163.23(13).

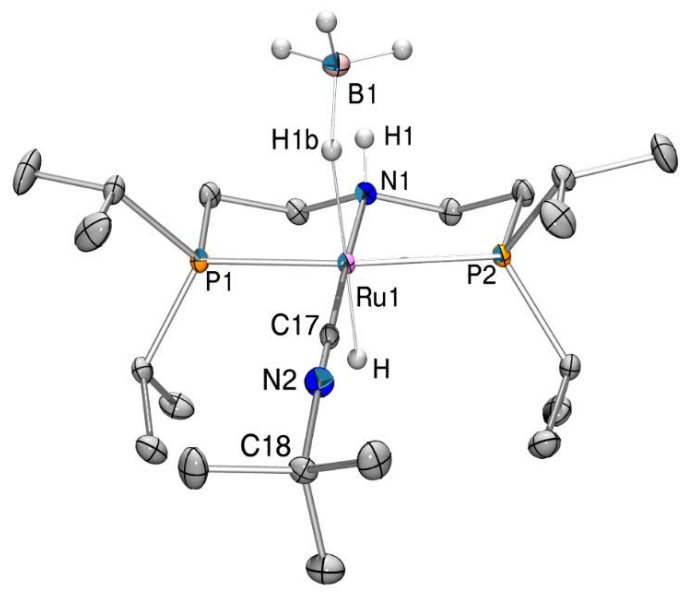

Figure 3. ORTEP view of solid-state structure of 3c. All $\mathrm{H}$ atoms (except the $\mathrm{H}$ on $\mathrm{Ru}, \mathrm{B}$ and $\mathrm{N}$ ) are omitted for clarity. Selected bond distances $(\AA)$ : Ru1-P1 = 2.3089(3), Ru1-P2 = 2.3009(3), Ru1-N1 $=2.1914(11), \mathrm{Ru} 1-\mathrm{C} 17=1.8886(13), \mathrm{Ru} 1-\mathrm{H} 1 \mathrm{~B}=1.834(17), \mathrm{Ru} 1-$ $\mathrm{H}=1.559$ (17). Selected angles (deg): P1-Ru1-H1B = 91.4(5), P1$\mathrm{Ru} 1-\mathrm{H}=88.7(6), \mathrm{P} 2-\mathrm{Ru} 1-\mathrm{P} 1=165.350(12), \mathrm{P} 2-\mathrm{Ru} 1-\mathrm{H} 1 \mathrm{~B}=$ 93.4(5), P2-Ru1-H = 87.5(6), N1-Ru1-P1 = 82.85(3), N1-Ru1-P2 $=82.93(3), \mathrm{N} 1-\mathrm{Ru} 1-\mathrm{H} 1 \mathrm{~B}=95.3(5), \mathrm{N} 1-\mathrm{Ru} 1-\mathrm{H}=88.5(6), \mathrm{C} 17-$ $\mathrm{Ru} 1-\mathrm{P} 1=97.25(4), \mathrm{C} 17-\mathrm{Ru} 1-\mathrm{P} 2=96.73(4), \mathrm{C} 17-\mathrm{Ru} 1-\mathrm{N} 1=$ 176.51(5), C17-Ru1-H1B = 88.2(5), C17-Ru1-H = 88.0(6), H1B$\mathrm{Ru} 1-\mathrm{H}=176.3(8), \mathrm{C} 17-\mathrm{N} 2-\mathrm{C} 18=160.70(13)$.

Use of a stoichiometric quantity of $\mathrm{NaBH}_{4}$ towards 1a-c in EtOH allows to predominantly produce the hydridochloride $\left[\mathrm{Ru}(\mathrm{H})(\mathrm{Cl})(\mathrm{CN}-\mathrm{R})\left(\mathrm{PNP}^{\mathrm{H}}\right)\right]$ species 4a-c, along with small amount of 3a-c $(<5 \%)$ (Scheme 2). Complexes 4a-c can be obtained as pure products in 55-62\% isolated yield range upon crystallization from a toluene $/ n$-pentane mixture at $-18^{\circ} \mathrm{C}$. As for the 3a-c hydridoborohydride derivatives, these display NMR features similar to that of their carbonyl parent compound, 
$\left[\mathrm{Ru}(\mathrm{H})(\mathrm{Cl})(\mathrm{CO})\left(\mathrm{PNP}^{\mathrm{H}}\right)\right]$. The isonitrile hydridochloride species ${ }^{31} \mathrm{P}$ NMR chemical shift of about $74 \mathrm{ppm}$ compares well to that of the $\mathrm{CO}$ derivative (75.8 ppm). In addition, the $\mathrm{RuH}{ }^{1} \mathrm{H}$ NMR signal appears as triplet centered at about $-17.5 \mathrm{ppm}$ for $\mathbf{4 a - c}$, to be compared to $-16.30 \mathrm{ppm}$ for the carbonyl analogue. The retention of the $\mathrm{N}-\mathrm{H}$ moiety is evidenced by the $v(\mathrm{~N}-\mathrm{H})$ at about $3170 \mathrm{~cm}^{-1}$, and by the ${ }^{15} \mathrm{~N}$ NMR signal at about $54 \mathrm{ppm}$. This rules out the presence of cationic species $\left[\mathrm{Ru}(\mathrm{H})(\mathrm{CN}-\mathrm{R})\left(\mathrm{PNP}^{\mathrm{H}}\right)\right]^{+}$with outer-sphere, $\mathrm{H}$ bonded chloride counter-cation, as was observed in the case of the more sterically $\left.\left[\mathrm{Ru}(\mathrm{H})(\mathrm{CO})\left(\mathrm{HN}\left\{\mathrm{CH}_{2} \mathrm{CH}_{2} \mathrm{P}(t \mathrm{Bu})_{2}\right)_{2}\right\}\right)\right]^{+}$. Error! Bookmark not defined.

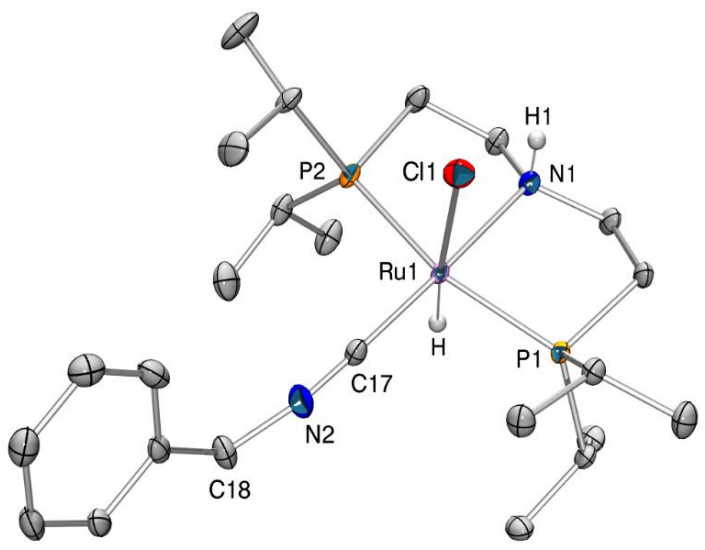

Figure 4. ORTEP view of solid-state structure of $\mathbf{4 a}$. All $\mathrm{H}$ atoms (except the $\mathrm{H}$ on $\mathrm{Ru}$ and $\mathrm{N}$ ) are omitted for clarity. Selected bond distances $(\AA)$ : Ru1-P1 = 2.3225(4), Ru1-Cl1 = 2.5555(4), Ru1-P2 $=2.3050(4), \mathrm{Ru} 1-\mathrm{N} 1=2.1931(13), \mathrm{Ru} 1-\mathrm{C} 17=1.8819(16), \mathrm{Ru} 1-\mathrm{H}$ $=1.56(2), \mathrm{N} 2-\mathrm{C} 17=1.179(2)$. Selected angles $(\mathrm{deg}): \mathrm{P} 1-\mathrm{Ru} 1-\mathrm{Cl} 1$ $=88.995(13), \mathrm{P} 1-\mathrm{Ru} 1-\mathrm{H}=89.4(8), \mathrm{Cl} 1-\mathrm{Ru} 1-\mathrm{H}=173.5(8), \mathrm{P} 2-$ Ru1-P1 = 164.463(14), P2-Ru1-Cl1 = 92.044(14), P2-Ru1-H = 87.8(8), N1-Ru1-P1 = 82.71(3), N1- Ru1-Cl1 = 84.05(4), N1-Ru1$\mathrm{P} 2=81.98(3), \mathrm{N} 1-\mathrm{Ru} 1-\mathrm{H}=89.5(8), \mathrm{C} 17-\mathrm{Ru} 1-\mathrm{P} 1=100.38(5)$, $\mathrm{C} 17-\mathrm{Ru} 1-\mathrm{Cl} 1=99.67(5), \mathrm{C} 17-\mathrm{Ru} 1-\mathrm{P} 2=94.73(5), \mathrm{C} 17-\mathrm{Ru} 1-\mathrm{N} 1=$ 175.16(5), C17-Ru1-H = 86.8(8), C17-N2-C18 = 154.34(16).

This was confirmed by X-ray diffraction studies on $\mathbf{4 a}$ and $\mathbf{4 c}$ (Figures 4 and 5). These compounds adopt a distorted octahedral configuration, with the PNP ligand set in a meridional arrangement. Their structure is similar to that of above-described $\mathbf{3 b}$ and $\mathbf{3 c}$, with the borohydride being formally substituted by a chloride ligand, or to that of the $\mathrm{CO}$ analogue, $\left[\mathrm{Ru}(\mathrm{H})(\mathrm{Cl})(\mathrm{CO})\left(\mathrm{PNP}^{\mathrm{H}}\right)\right]$.

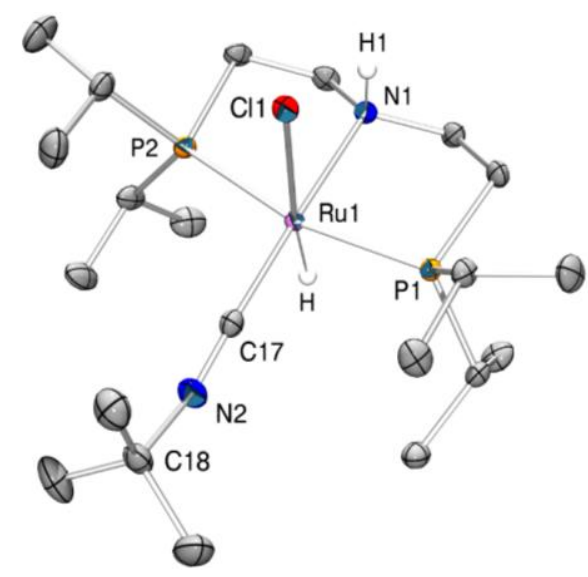

Figure 5. ORTEP view of solid-state structure of 4c. All $\mathrm{H}$ atoms (except the $\mathrm{H}$ on $\mathrm{Ru}$ and $\mathrm{N}$ ) are omitted for clarity. Selected bond distances $(\AA)$ : Ru1-Cl1 = 2.5426(3), Ru1-P1 = 2.3097(3), Ru1 P2 2.3071(3), Ru1-N1 = 2.1783(10), Ru1-C17 = 1.8831(13), Ru1-H =
$1.588(17), \mathrm{N} 2-\mathrm{C} 17=1.1847(17)$. Selected angles (deg): Cl1-Ru1$\mathrm{H}=172.9(6), \mathrm{P} 1-\mathrm{Ru} 1-\mathrm{Cl} 1=89.589(12), \mathrm{P} 1-\mathrm{Ru} 1-\mathrm{H}=88.6(6), \mathrm{P} 2-$ Ru1-C11 = 90.372(12), P2-Ru1-P1 = 165.230(12), P2-Ru1-H = 89.6(6), N1-Ru1-Cl1 = 83.91(3), N1-Ru1-P1 = 82.92(3), N1-Ru1$\mathrm{P} 2=82.39(3), \mathrm{N} 1-\mathrm{Ru} 1-\mathrm{H}=89.0(6), \mathrm{C} 17-\mathrm{Ru} 1-\mathrm{Cl} 1=100.19(4)$, $\mathrm{C} 17-\mathrm{Ru} 1-\mathrm{P} 1=96.96(4), \mathrm{C} 17-\mathrm{Ru} 1-\mathrm{P} 2=97.58(4), \mathrm{C} 17-\mathrm{Ru} 1-\mathrm{N} 1=$ 175.90(5), C17-Ru1-H = 86.9(6), C17-N2-C18 = 154.91(14).

Reaction of $\mathbf{4 a - c}$ with excess of $\mathrm{NaBH}_{4}$ resulted in the formation of 3a-c in quantitative manner based on ${ }^{1} \mathrm{H}$ and ${ }^{31} \mathrm{P}$ NMR (Scheme 2). On the other hand, reaction of $\mathbf{1 a}$ with 1.0 equiv. of $\mathrm{NaHBEt}_{3}$ does not afford 4a. Instead, the dihydride complex $\left[\mathrm{Ru}(\mathrm{H})_{2}(\mathrm{CN}-\right.$ $\left.\left.\mathrm{CH}_{2} \mathrm{Ph}\right)\left(\mathrm{PNP}^{\mathrm{H}}\right)\right] \mathbf{5 a}$ was obtained, with a NMR yield of about $50 \%$. This indicates that the reaction of $1 \mathbf{a}$ with $\mathrm{NaHBEt}_{3}$ to form the intermediate $4 \mathbf{a}$ takes place with lower rate than that of $\mathbf{4 a}$ with $\mathrm{NaHBEt}_{3}$ to form 5a, probably due to the higher solubility of intermediate 4a with respect to the starting compound 1a. Addition of 2 equiv. of NaHBEt 3 to the suspension of 1 a resulted in the full conversion of the latter, affording $\mathbf{5} \mathbf{a}$ as the main species, along with some unidentified hydride ruthenium products. Attempts to isolate 5a as a pure product were unsuccessful as the compound suffers from low stability, affording unidentified species upon standing at room temperature in solution. Thus, $\mathbf{5} \mathbf{a}$ was characterized in-situ by ${ }^{1} \mathrm{H}$ and ${ }^{31} \mathrm{P}$ NMR: Ru-H hydrides resonate as two triplets of doublets centered at $-6.25\left({ }^{2} J_{\mathrm{HH}}=6.8 \mathrm{~Hz},{ }^{2} J_{\mathrm{HP}}=18.4 \mathrm{~Hz}\right)$ and at -6.48 $\left({ }^{2} J_{\mathrm{HH}}=6.9 \mathrm{~Hz},{ }^{2} J_{\mathrm{HP}}=19.0 \mathrm{~Hz}\right)$, while the ${ }^{31} \mathrm{P}\left\{{ }^{1} \mathrm{H}\right\}$ spectrum features a singlet at $86.89 \mathrm{ppm}$, in line with a structure featuring two equivalent phosphorus atoms.

Similar reaction with $\mathrm{NaHBEt}_{3}$ was performed with $\mathbf{1 c}$, resulting in the formation of a mixture of two stereoisomeric compounds, meridional $\boldsymbol{m e r}-\mathbf{5 c}$ and facial $\boldsymbol{f a c}-\mathbf{5 c}$ of general formula $\left[\mathrm{Ru}(\mathrm{H})_{2}(\mathrm{NC}-\right.$ $\left.t \mathrm{Bu})\left(\mathrm{PNP}^{\mathrm{H}}\right)\right]$ in respective ratio of $1.5 / 1$ with a cumulated isolated yield of $62 \%$ after crystallization from toluene $/ n$-pentane at low temperature. The higher stability of $\mathbf{m e r}-\mathbf{5 c} / f a c-5 \mathbf{c}$ with respect to that of 5a could be attributed to the bulkier nature of $t$-butyl groups that may stabilize the hydride species. As a comparison, Gusev isolated a structurally related $f a c-\left[\mathrm{Ru}(\mathrm{H})_{2}\left(\mathrm{PPh}_{3}\right)\left\{\mathrm{HN}\left(\mathrm{C}_{2} \mathrm{H}_{4} \mathrm{SEt}\right)_{2}\right\}\right]$

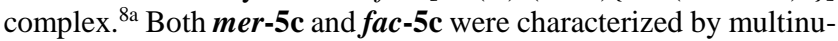
clear NMR spectroscopy and X-ray diffraction. For $\boldsymbol{m e r - 5 c}$, two inequivalent $\mathrm{Ru}-\mathrm{H}$ hydrides resonate as one triplet of doublets centered at $-6.86\left({ }^{2} J_{\mathrm{HH}}=4.9 \mathrm{~Hz},{ }^{2} J_{\mathrm{HP}}=18.0 \mathrm{~Hz}\right)$ and one broadened triplet at $-7.05 \mathrm{ppm}\left({ }^{2} J_{\mathrm{HP}}=19.0 \mathrm{~Hz}\right)$ that are assigned to the $\mathrm{Ru}-\mathrm{H}$ in anti- and syn-positions with respect to $\mathrm{NH}$ proton, respectively (Figure 6). The latter one is slightly broadened probably due to a weak interaction with the NH proton. The ${ }^{31} \mathrm{P}\left\{{ }^{1} \mathrm{H}\right\}$ spectrum displays a singlet at $84.78 \mathrm{ppm}$. The ${ }^{15} \mathrm{~N}$ chemical shifts values were determined at 31.0 and $184.6 \mathrm{ppm}$ for the $\mathrm{NH}$ and isonitrile functions, respectively. For the $f a c-5 \mathbf{c}_{2}$, the two chemically equivalent $\mathrm{Ru}-\mathrm{H}$ hydrides resonate as a multiplet centered at $-8.82 \mathrm{ppm}$. The ${ }^{31} \mathrm{P}\left\{{ }^{1} \mathrm{H}\right\}$ spectrum displays a singlet at $74.08 \mathrm{ppm}$. The ${ }^{15} \mathrm{~N}$ chemical shift values for the complex were determined at 19.5 and 178.0 ppm (assigned to $\mathrm{NH}$ and isonitrile functions, respectively) thanks to HSQC and HMBC experiments. 

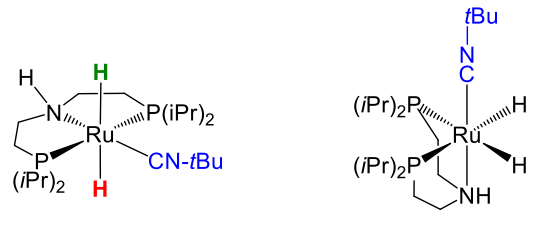

mer-5c

fac-5c

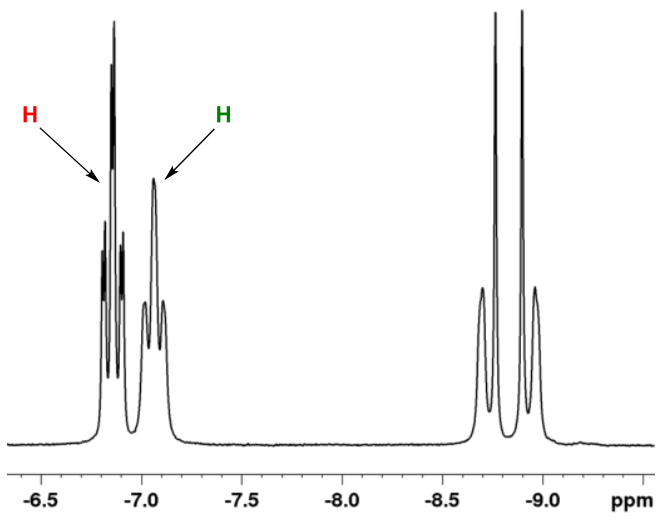

Figure 6. Hydride region of the ${ }^{1} \mathrm{H}$ NMR spectrum of the mer$\mathbf{5 c / f a c}-\mathbf{5 c}$ mixture $(400 \mathrm{MHz})$.

Though purification attempts were not met with success, due to thermal instability of the bishydride species, we succeeded in obtaining single crystals from a synthesis batch. Remarkably, both $m e r$ and $f a c$ isomers, $\boldsymbol{m e r - 5 c}$ and $\boldsymbol{f a c}-\mathbf{5 c}$, co-crystallized along with one molecule of $\mathrm{NaBEt}_{4}$. As seen on Figure 7, they thus form an entity where the two different ruthenium bishydride isomers assemble around a sodium cation, with tetraethylborate as non-interacting counteranion (Figure 7). ${ }^{24}$ The two organometallic fragments arrange around the sodium so that the isonitrile ligands are organized in eclipsed, head-to-tail configurations. The ruthenium fragments both feature a distorted octahedral configuration. Within mer-5c, the PNP ligand set binds to the metal center in a meridional arrangement. The tert-butylisonitrile ligand is in trans position with respect to the PNP framework's nitrogen. Accordingly, both hydrides $\left(\mathrm{H}_{\mathrm{a}}\right.$ and $\mathrm{H}_{\mathrm{c}}$ on Figure 7$)$ are in mutual trans-position. For $f a c-5 c$, the PNP ligand set features a facial arrangement. The tertbutylisonitrile ligand is in trans-position with respect to the PNP's nitrogen. Both hydrides $\left(\mathrm{H}\right.$ and $\mathrm{H}_{\mathrm{b}}$ on Figure 7 ) are in mutual cis position. The $\mathrm{Ru}-\mathrm{C}$ bond distance of $\boldsymbol{m e r - 5 c}(\mathrm{Ru} 1-\mathrm{C} 17=1.871(4)$ $\AA)$ is shorter than that of $\boldsymbol{f a c}-\mathbf{5 c}(\mathrm{Ru} 2-\mathrm{C} 38=1.893(4) \AA)$. This owes in part to the interaction with the intercalated $\mathrm{Na}$ cation, which is preferentially interacting with the $\boldsymbol{m e r - 5 c}$ framework. This reflects in the Na1-C17 and Na1-N2 distances of 2.619(4) and 2.671(4) $\AA$, respectively, which are shorter than the Na1-C38 and Na1-N4 distances of 2.784(4) and 3.297(5) $\AA$, respectively. The sodium is also stabilized by further interaction with the two mutually cis hydrides from $\boldsymbol{m e r - 5 c}$ (Na1-H: 2.22(5) $\AA$ and Na1-Hb: 2.31(5) $\AA$ ) and with a single hydride from $\mathbf{5 c}$ with a significantly shorter Na1-Hc distance of 2.06(6) $\AA$.

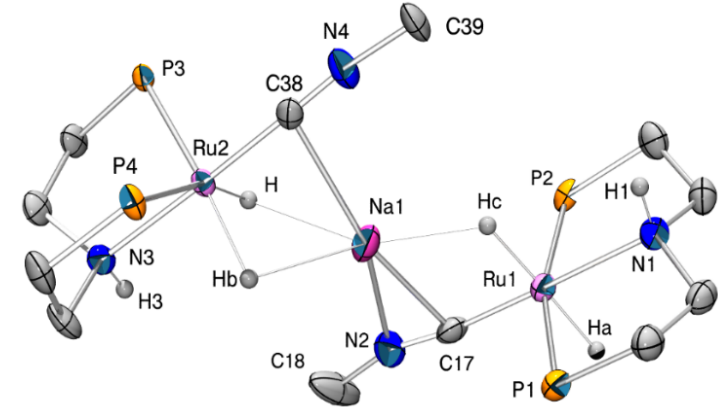

Figure 7. ORTEP view of solid-state structure of the cation from 5c'NaBEt 4 . All $\mathrm{H}$ atoms (except those on $\mathrm{Ru}$ and $\mathrm{N}$ ), $i$ Pr groups on $\mathrm{P}, \mathrm{Me}$ groups from $t \mathrm{Bu}$ moieties and the $\mathrm{BEt}_{4}{ }^{-}$anion are omitted for clarity. Selected bond distances $(\AA)$ : $\boldsymbol{m e r}-5 \mathbf{c}$ : $\mathrm{Ru} 1-\mathrm{P} 2=2.2945(10)$, $\mathrm{Ru} 1-\mathrm{P} 1=2.2942(11), \mathrm{Ru} 1-\mathrm{N} 1=2.218(3), \mathrm{Ru} 1-\mathrm{C} 17=1.871(4)$, $\mathrm{Ru} 1-\mathrm{HA}=1.62(5), \mathrm{Ru} 1-\mathrm{Hc}=1.607(10), \mathrm{N} 2-\mathrm{C} 17=1.193(5)$. fac 5c: $\mathrm{Ru} 2-\mathrm{P} 3=2.3208(9), \mathrm{Ru} 2-\mathrm{P} 4=2.3142(9), \mathrm{Ru} 2-\mathrm{N} 3=2.219(3)$, $\mathrm{Ru} 2-\mathrm{C} 38=1.893(4), \mathrm{Ru} 2-\mathrm{H}=1.66(5), \mathrm{Ru} 2-\mathrm{Hb}=1.68(5), \mathrm{N} 4-\mathrm{C} 38$ $=1.174(5)$. Selected angles (deg): mer-5c: P2-Ru1-Ha = 87.3(19), $\mathrm{P} 2-\mathrm{Ru} 1-\mathrm{Hc}=$ 94(3), P1-Ru1-P2 = 163.97(4), P1-Ru1-Ha = 85.4(19), P1-Ru1-Hc = 93(3), N1-Ru1-P2 = 82.15(9), N1-Ru1-P1 $=83.33(9), \mathrm{N} 1-\mathrm{Ru} 1-\mathrm{Ha}=87.9(19), \mathrm{N} 1-\mathrm{Ru} 1-\mathrm{Hc}=93(3), \mathrm{C} 17-\mathrm{Ru} 1-$ $\mathrm{P} 2=98.04(12), \mathrm{C} 17-\mathrm{Ru} 1-\mathrm{P} 1=96.64(12), \mathrm{C} 17-\mathrm{Ru} 1-\mathrm{N} 1=$ 178.68(15), C17-Ru1-Ha = 93.4(19), C17-Ru1-Hc = 86(3), Ha$\mathrm{Ru} 1-\mathrm{Hc}=178(3), \mathrm{C} 17-\mathrm{N} 2-\mathrm{C} 18=157.9(5)$. fac $-5 \mathrm{c}: \mathrm{P} 3-\mathrm{Ru} 2-\mathrm{H}=$ 81.0(16), P3-Ru2-Hb = 159.8(18), P4-Ru2-P3 = 110.82(3), P4$\mathrm{Ru} 2-\mathrm{H}=163.5(16), \mathrm{P} 4-\mathrm{Ru} 2-\mathrm{Hb}=84.3(18), \mathrm{N} 3-\mathrm{Ru} 2-\mathrm{P} 3=82.67(8)$, $\mathrm{N} 3-\mathrm{Ru} 2-\mathrm{P} 4=82.25(9), \mathrm{N} 3-\mathrm{Ru} 2-\mathrm{Na} 1=117.01(9), \mathrm{N} 3-\mathrm{Ru} 2-\mathrm{H}=$ 88.1(16), N3-Ru2-Hb = 86.3(18), C38-Ru2-P3 = 97.73(10), C38Ru2-P4 94.48(11), C38-Ru2-N3 = 176.61(14), C38-Ru2-H = 95.3(16), C38-Ru2-Hb = 94.3(18), H-Ru2-Hb = 82(2), C38-N4$\mathrm{C} 39=171.6(4)$.

In analogy with the well-known chemistry of the hydrido chloro carbonyl derivatives, preparation of the amido species through $\mathrm{N}$ $\mathrm{H}$ deprotonation of the hydrido chloro isonitrile species was attempted. Thus, reaction of $\mathbf{4 c}$ with $t \mathrm{BuOK}$ (1.0 equiv.) was performed, leading to the formation of a new amido complex $[\mathrm{Ru}(\mathrm{H})(\mathrm{CN}-t \mathrm{Bu})(\mathrm{PNP})](\mathbf{6}$, Scheme 3). Attempts to isolate this compound were unsuccessful, due to its low stability. Thus, formation of $\mathbf{6}$ was proposed based on in-situ NMR characterization: In the hydride region, the ${ }^{1} \mathrm{H}$ NMR spectrum displays a triplet centered at $-18.74 \mathrm{ppm}\left({ }^{2} J_{\mathrm{HP}}=16.5 \mathrm{~Hz}\right)$. The ${ }^{31} \mathrm{P}\left\{{ }^{1} \mathrm{H}\right\}$ NMR spectrum features a singlet at $91.8 \mathrm{ppm}$. In comparison, $\left[\mathrm{Ru}(\mathrm{H})(\mathrm{CO})\left(\mathrm{PNP}{ }^{\prime}\right)\right]$ features ${ }^{1} \mathrm{H}$ and ${ }^{31} \mathrm{P}$ NMR signals at -18.71 and $94.0 \mathrm{ppm}$; respectively. The fate of this complex remains undetermined, as decomposition into an unidentified mixture of products occurred.

In the presence of excess benzylisonitrile, the hydrido chloride derivative $\mathbf{4 a}$ reacts to afford the cationic species $\left[\mathrm{Ru}(\mathrm{H})\left(\mathrm{CNCH}_{2} \mathrm{Ph}\right)_{2}\left(\mathrm{PNP}^{\mathrm{H}}\right)\right]^{+}\left(\mathrm{Cl}^{-}\right)(7$, Scheme 3$)$. The solid state structure of this complex was established by a single crystal X-rays diffraction study (Figure 8). 7 features a distorted octahedral geometry, with the PNP ligand in meridional configuration. The two isonitrile ligands occupy two mutually cis-positions, one being coordinated in the trans position amino group, and the other in cis position compared to the $\mathrm{N}-\mathrm{H}$ functionality. Noteworthy, the (N1-H1 $\cdots \mathrm{Cl1}$ ) distance of 2.433(2) $\AA$ and the corresponding angle $(\mathrm{N} 1-\mathrm{H} 1 \cdots \mathrm{Cl1})$ of $164.8(1)^{\circ}$ are indicative of a weak-strength hydrogen-bonding interaction involving $(\mathrm{N}-\mathrm{H} \cdots \mathrm{Cl})$ atoms. ${ }^{25}$ In addition, the Ru1-C17 bond distance (2.0056(11) $\tilde{\mathrm{A}}$ ) is longer than the Ru1-C25 bond distance (1.9070(11) A), likely due to the trans-influence of the hydride ligand exerted on the former. 


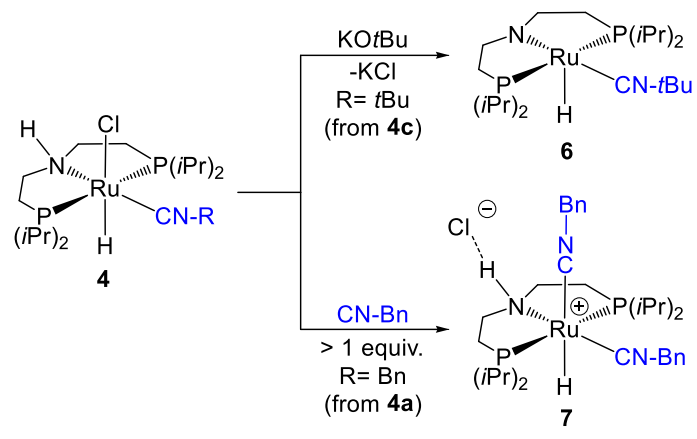

Scheme 3. Reactivity examples of $4 a$ and $4 c$

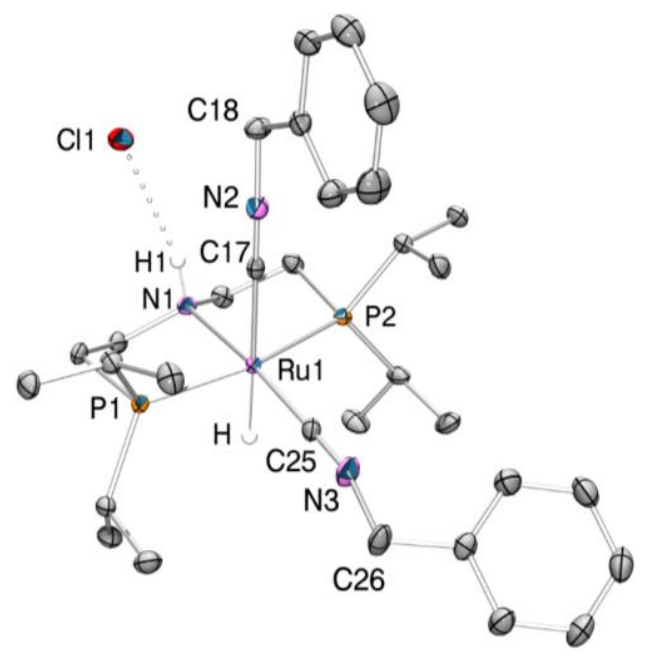

Figure 8. ORTEP view of solid-state structure of 7. All $\mathrm{H}$ atoms (except the $\mathrm{H}$ on $\mathrm{Ru}$ and $\mathrm{N}$ ) are omitted for clarity. Selected bond distances $(\AA): \mathrm{Ru} 1-\mathrm{P} 1=2.3258(3), \mathrm{Ru} 1-\mathrm{P} 2=2.3287(3), \mathrm{Ru} 1-\mathrm{N} 1$ $=2.1880(9), \mathrm{Ru} 1-\mathrm{C} 17=2.0056(11), \mathrm{Ru} 1-\mathrm{C} 25=1.9070(11), \mathrm{Ru} 1-$ $\mathrm{H}=1.622(17), \mathrm{N} 2-\mathrm{C} 17=1.1609(15), \mathrm{N} 3-\mathrm{C} 25=1.1686(15)$. Selected angles (deg): $\mathrm{P} 1-\mathrm{Ru} 1-\mathrm{P} 2=165.235(11), \mathrm{P} 1-\mathrm{Ru} 1-\mathrm{H}=$ 88.5(6), P2-Ru1-H = 88.1(6), N1-Ru1-P1 = 82.68(3), N1-Ru1-P2 $=82.78(3), \mathrm{N} 1-\mathrm{Ru} 1-\mathrm{H}=86.8(6), \mathrm{C} 17-\mathrm{Ru} 1-\mathrm{P} 1=92.36(3), \mathrm{C} 17-$ $\mathrm{Ru} 1-\mathrm{P} 2=90.04(3), \mathrm{C} 17-\mathrm{Ru} 1-\mathrm{N} 1=89.37(4), \mathrm{C} 17-\mathrm{Ru} 1-\mathrm{H}=$ 175.9(6), C25-Ru1-P1 = 95.53(3), C25-Ru1-P2 = 98.66(3), C25$\mathrm{Ru} 1-\mathrm{N} 1=173.82(4), \mathrm{C} 25-\mathrm{Ru} 1-\mathrm{C} 17=96.62(5), \mathrm{C} 25-\mathrm{Ru} 1-\mathrm{H}=$ 87.3(6), C17-N2-C18 = 175.61(12), C25 N3 C26 = 165.79(13).

Spectroscopic features of 7 are in line with this structure. On the ${ }^{1} \mathrm{H}$ NMR spectrum, the $\mathrm{RuH}$ and the $\mathrm{N}-\mathrm{H}$ resonate at -8.48 and 8.43 ppm, respectively (Figure 9). The latter chemical shift (being severely low-field shifted compared to non-interacting $\mathrm{NH}$ moieties) combined with the $v(\mathrm{~N}-\mathrm{H})$ band at $3055 \mathrm{~cm}^{-1}$ on the IR spectrum, is indicative of H-bonding between the amino hydrogen and the chloride atom. Furthermore, the low field shift of this hydride peak stems from the strong trans-effect from the opposite axial isonitrile ligand. As a comparison, the ${ }^{1} \mathrm{H}$ chemical shift of the similar cationic bis-carbonyl $\left[\mathrm{Ru}(\mathrm{H})(\mathrm{CO})_{2}\left(\mathrm{PNP}^{\mathrm{H}}\right)\right]^{+}$hydride is of $-6.2 \mathrm{ppm} .{ }^{26}$ ${ }^{1} \mathrm{H}-{ }^{1} \mathrm{H}$ 2D NOESY experiment shows no through-space correlation between the $\mathrm{Ru}-\mathrm{H}$ hydride peak and the $\mathrm{N}-\mathrm{H}$ peak, indicating a mutually anti-arrangement of the $\mathrm{Ru}-\mathrm{H}$ and $\mathrm{N}-\mathrm{H}$ fragments. In addition, the presence of two different isonitrile ligands is evidenced by the two ${ }^{15} \mathrm{~N}$ NMR signals at 172.8 and $159.4 \mathrm{ppm}$, and by the two $v(\mathrm{C} \equiv \mathrm{N})$ bands at 2135 and $2059 \mathrm{~cm}^{-1}$ on the infrared spectrum. The ${ }^{13} \mathrm{C}\left\{{ }^{1} \mathrm{H}\right\}$ spectrum displays two downfield triplets centered at $171.38\left({ }^{2} J_{\mathrm{CP}}=11.0 \mathrm{~Hz}\right)$ and $157.42 \mathrm{ppm}\left({ }^{2} J_{\mathrm{CP}}=8.4 \mathrm{~Hz}\right)$ : The less downfield signal is attributed to the isonitrile carbon atom in transposition with respect to the hydride ligand (trans-effect) while the more downfield one is assigned to the isonitrile carbon atom in cisposition to the hydride ligand.

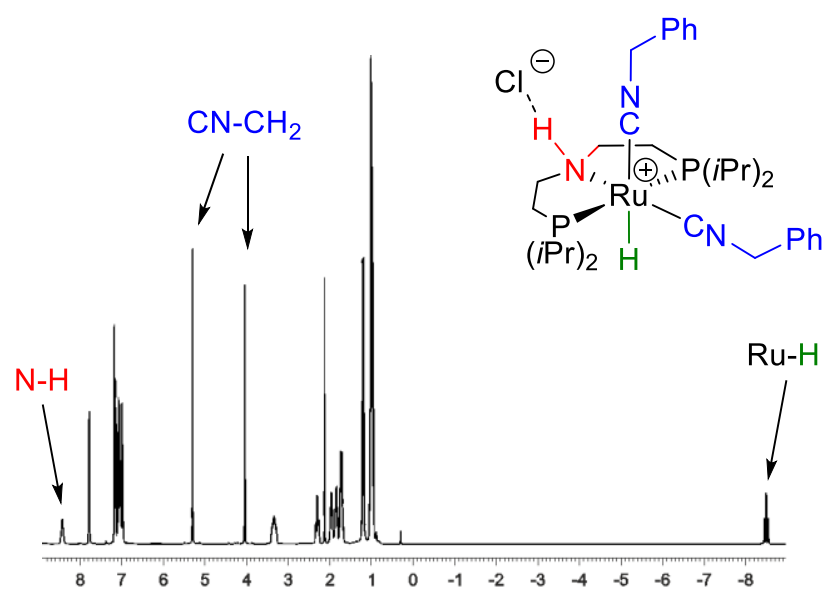

Figure 9. ${ }^{1} \mathrm{H}$ NMR spectrum of 7 (400 MHz, C6D6, $300 \mathrm{~K}$ )

Bearing in mind the recent progresses on the use of Earth-abundant metal complexes as efficient catalysts in hydrogenation and dehydrogenation processes, ${ }^{10,27}$ the analogous iron chemistry was also explored, following on the work of Hazari and collaborators on arylisonitrile PNP complexes. ${ }^{13}$ Synthetic studies were performed starting from the iron (II) complex $\left[\mathrm{Fe}(\mathrm{Br})_{2}\left(\mathrm{PNP}^{\mathrm{H}}\right)\right]$.ref In contrast to ruthenium chemistry, the reaction with benzylisonitrile (even upon addition of sub-equivalent quantities of isonitrile) exclusively lead to the formation of the ionic complex of formula $\left[\mathrm{Fe}(\mathrm{Br})\left(\mathrm{CNCH}_{2} \mathrm{Ph}\right)_{2}\left(\mathrm{PNP}^{\mathrm{H}}\right)\right]^{+}\left(\mathrm{Br}^{-}\right) \mathbf{8}($ Scheme 3). Formation of a neutral mono-ligated isonitrile $\left[\mathrm{Fe}(\mathrm{Br})_{2}\left(\mathrm{CNCH}_{2} \mathrm{Ph}\right)\left(\mathrm{PNP}^{\mathrm{H}}\right)\right]$ complex was not observed. Under similar conditions, Hazari et al. reported the formation of a mixture of neutral dichloride $\left[\mathrm{Fe}(\mathrm{Cl})_{2}\left(\mathrm{CNCH}_{2} \mathrm{Ph}\right)\left(\mathrm{PNP}^{\mathrm{H}}\right)\right]$ and cationic monochloride $\left[\mathrm{Fe}(\mathrm{Cl})\left(\mathrm{CNCH}_{2} \mathrm{Ph}\right)_{2}\left(\mathrm{PNP}^{\mathrm{H}}\right)\right]^{+}\left(\mathrm{Cl}^{-}\right)$when starting from the less sterically crowded $\left[\mathrm{Fe}(\mathrm{Cl})_{2}\left(\mathrm{PNP}^{\mathrm{H}}\right)\right]$ derivative (chloride being smaller than bromide). ${ }^{13}$

Extensive NMR characterization studies on $\mathbf{8}$ revealed that there are actually two stereo-isomers formed in 15.6/1 ratio: the major (cis-8) comprizes two isonitrile ligands in mutually cis-position while the minor one (trans-8) has two isonitrile moieties in mutually trans position. The relevant ${ }^{13} \mathrm{C}$ NMR signals of isonitrile $\mathrm{C} \equiv \mathrm{N}$ carbons are determined at 171 and 166 ppm for cis-8 and at 174 and $168 \mathrm{ppm}$ for trans-8. The corresponding isonitrile nitrogen resonates at 188.7 and $183.5 \mathrm{ppm}$ for $\boldsymbol{c i s} \mathbf{- 8}$ and at 186.3 and $183.2 \mathrm{ppm}$ for trans-8. Salt metathesis reaction of 8 with excess $\mathrm{NaBPh}_{4}$ followed by recrystallization produced the complex $\left[\mathrm{Fe}(\mathrm{Br})\left(\mathrm{CNCH}_{2} \mathrm{Ph}\right)_{2}\left(\mathrm{PNP}^{\mathrm{H}}\right)\right]^{+}\left(\mathrm{BPh}_{4}^{-}\right) 9$ in moderate isolated yield $(53 \%) .{ }^{28}$ The NH proton of cis-8 resonates at lower field (6.51 ppm) with respect to that of $9(2.40 \mathrm{ppm})$ which is in line with a $(\mathrm{N}$ $\mathrm{H} \cdots \mathrm{Br}$ ) hydrogen bonding interaction in the former, and no $\mathrm{H}$ bonding interaction in the latter. Accordingly, the $v(\mathrm{~N}-\mathrm{H})$ of $\boldsymbol{c i s}-\mathbf{8}$ is found at about $165 \mathrm{~cm}^{-1}$ lower wavenumbers compared to that of 9 (3061 vs. $3227 \mathrm{~cm}^{-1}$, respectively). The solid-state structure of cis-8 and 9 were further determined by X-ray diffraction analysis (Figure 10 for $\boldsymbol{c i s - 8}$; Figure 11 for 9 see Supporting Information). Complex cis-8 features a distorted octahedral geometry with the PNP ligand in meridional configuration. Similarly to 7, two isoni-

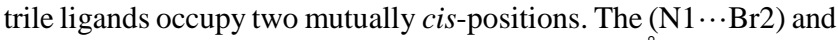
$(\mathrm{N} 1-\mathrm{H} 1 \cdots \mathrm{Br} 2)$ distances of 3.355(4) and 2.487(4) $\mathrm{A}$, respectively, and the corresponding angle $(\mathrm{N} 1-\mathrm{H} 1 \cdots \mathrm{Br} 2)$ of $168.82(3)^{\circ}$ are in- 
dicative of a weak-strength hydrogen-bonding interaction involving $(\mathrm{N}-\mathrm{H} \cdots \mathrm{Br})$ atoms. The solid-state structure of 9 is very close to that of $\boldsymbol{c i s - 8}$, excepted that, as the bromide counter-anion is replaced by tetraphenyl borate, the NH moiety is not involved in $\mathrm{H}$ bonding interaction.

In order to access catalytically relevant hydride species, the reaction of $\mathbf{8}$ with excess of $\mathrm{NaBH}_{4}$ was probed. It resulted in the formation of several unidentified complexes. Noteworthy, reaction of $\left[\mathrm{FeBr}_{2}\left(\mathrm{PNP}^{\mathrm{H}}\right)\right]$ with $t$-butylisonitrile and then with $\mathrm{NaBH}_{4}$ resulted in the formation of a new hydride iron complex of formula $\left[\mathrm{Fe}(\mathrm{H})(\mathrm{CN} t \mathrm{Bu})_{2}\left(\mathrm{PNP}^{\mathrm{H}}\right)\right]^{+}\left(\mathrm{BH}_{4}^{-}\right) \mathbf{1 0}$ in $49 \%$ yield that was fully characterized by IR and NMR spectroscopies (Scheme 3 ). ${ }^{1} \mathrm{H}$ and ${ }^{31} \mathrm{P}\left\{{ }^{1} \mathrm{H}\right\}$ NMR spectra display a characteristic hydride signal as a triplet centered at $-10.48 \mathrm{ppm}\left({ }^{2} J_{\mathrm{HP}}=50 \mathrm{~Hz}\right)$ and a singlet at 100.01 ppm, respectively. On the ${ }^{11} \mathrm{~B}$ NMR spectrum, the free $\mathrm{BH}_{4}$ anion resonates as a quintet centered at $-38.9 \mathrm{ppm}\left({ }^{1} J_{\mathrm{BH}}=82 \mathrm{~Hz}\right) .{ }^{13} \mathrm{C}\left\{{ }^{1} \mathrm{H}-\right.$ $\left.{ }^{31} \mathrm{P}\right\}$ NMR spectrum displays two downfield signals at 175.4 and $166.2 \mathrm{ppm}$ that are assigned to the two inequivalent $\mathrm{C} \equiv \mathrm{N}$ carbon atoms from the equatorial and axial isonitrile ligands, respectively. Thanks to ${ }^{1} \mathrm{H}-{ }^{15} \mathrm{~N}$ HSQC and ${ }^{1} \mathrm{H}-{ }^{15} \mathrm{~N}$ HMBC measurements, ${ }^{15} \mathrm{~N}$ chemical shift values of $\mathrm{NH}$ and isonitrile functions were determined to be $31.7,193.2$ and 196.5 ppm, respectively.

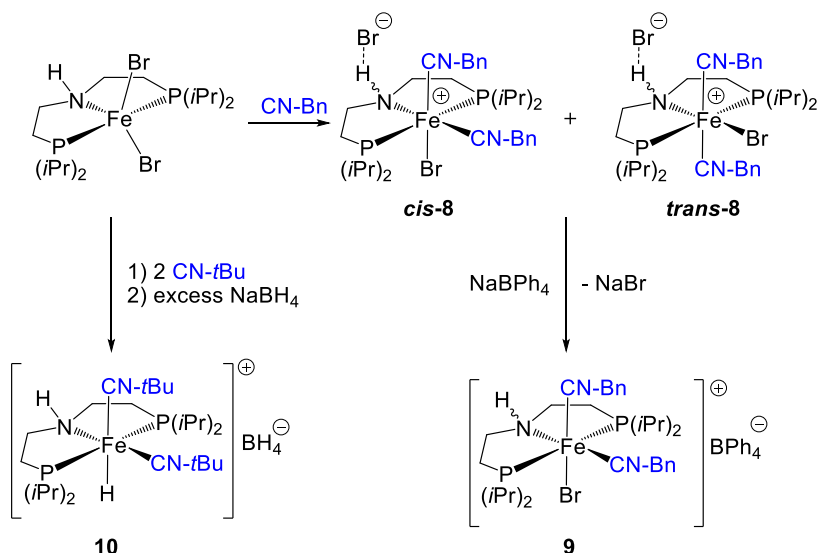

Scheme 3. General syntheses of iron complexes.

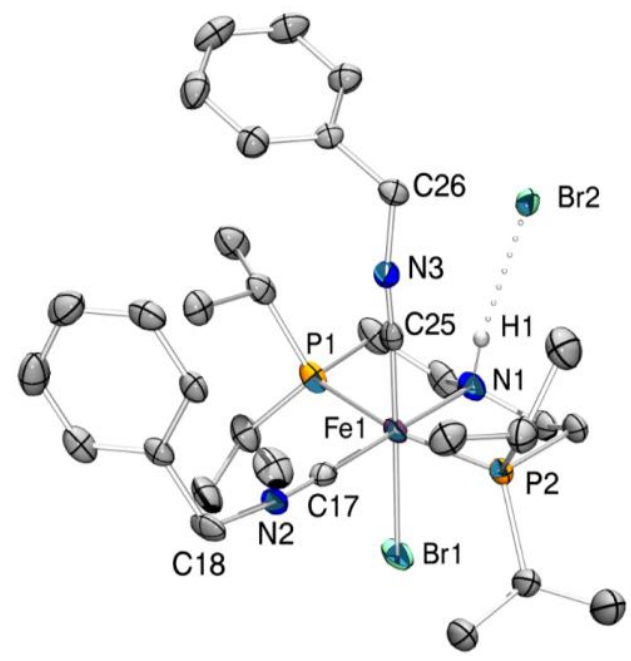

Figure 10. ORTEP view of solid-state structure of cis-8. All H atoms (except the $\mathrm{H}$ on $\mathrm{N}$ ) are omitted for clarity. Selected bond distances $(\AA): \mathrm{Br} 1-\mathrm{Fe} 1=2.4894(5), \mathrm{Fe} 1-\mathrm{P} 1=2.2804(9), \mathrm{Fe} 1-\mathrm{P} 2=$ 2.2840(9), Fe1-N1 = 2.073(2), Fe1-C25 = 1.826(3), Fe1-C17 = 1.824(3), N2-C17 = 1.160(3), N3-C25 = 1.152(3). Selected angles (deg): P1-Fe1-Br1 = 91.33(3), P1-Fe1-P2 = 168.03(3), P2-Fe1-Br1
$=90.70(2), \mathrm{N} 1-\mathrm{Fe} 1-\mathrm{Br} 1=88.28(7), \mathrm{N} 1-\mathrm{Fe} 1-\mathrm{P} 1=84.06(8), \mathrm{N} 1-$ $\mathrm{Fe} 1-\mathrm{P} 2=84.21(8), \mathrm{C} 25-\mathrm{Fe} 1-\mathrm{Br} 1=179.00(9), \mathrm{C} 25-\mathrm{Fe} 1-\mathrm{P} 1=$ 88.29(9), C25-Fe1-P2 = 89.86(9), C25-Fe1-N1 = 92.60(11), C17$\mathrm{Fe} 1-\mathrm{Br} 1=89.69(8), \mathrm{C} 17-\mathrm{Fe} 1-\mathrm{P} 1=95.11(9), \mathrm{C} 17-\mathrm{Fe} 1-\mathrm{P} 2=$ 96.70(9), C17-Fe1-N1 = 177.79(11), C17-Fe1-C25 = 89.42(12), C17-N2-C18 = 173.7(3), C25-N3-C26 169.2(3).

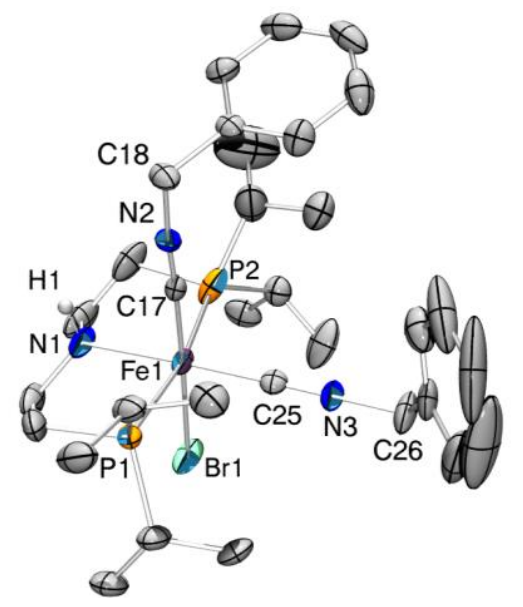

Figure 11. ORTEP view of solid-state structure of $9 . \mathrm{BPh}_{4}$ anion and all $\mathrm{H}$ atoms (except the $\mathrm{H}$ on $\mathrm{N}$ ) are omitted for clarity. Selected bond distances $(\AA)$ : $\mathrm{Br} 1-\mathrm{Fe} 1=2.5091(5), \mathrm{Fe} 1-\mathrm{P} 1=2.2726(10)$, $\mathrm{Fe} 1-\mathrm{P} 2=2.2638(11), \mathrm{Fe} 1-\mathrm{N} 1=2.073(3), \mathrm{Fe} 1-\mathrm{C} 25=1.828(3)$, $\mathrm{Fe} 1-\mathrm{C} 17=1.824(3), \mathrm{N} 2-\mathrm{C} 17=1.158(4), \mathrm{N} 3-\mathrm{C} 25=1.157(4)$. Selected angles (deg): $\mathrm{P} 1-\mathrm{Fe} 1-\mathrm{Br} 1=90.22(3), \mathrm{P} 1-\mathrm{Fe} 1-\mathrm{P} 2=$ 169.75(4), $\mathrm{P} 2-\mathrm{Fe} 1-\mathrm{Br} 1=91.07(3), \mathrm{N} 1-\mathrm{Fe} 1-\mathrm{Br} 1=88.72(8), \mathrm{N} 1-$ $\mathrm{Fe} 1-\mathrm{P} 1=84.53(10), \mathrm{N} 1-\mathrm{Fe} 1-\mathrm{P} 2=85.32(10), \mathrm{C} 25-\mathrm{Fe} 1-\mathrm{Br} 1=$ 88.83(9), C25-Fe1-P1 = 95.67(10), C25-Fe1-P2 = 94.52(10), C25$\mathrm{Fe} 1-\mathrm{N} 1=177.55(12), \mathrm{C} 17-\mathrm{Fe} 1-\mathrm{Br} 1=178.25(9), \mathrm{C} 17-\mathrm{Fe} 1-\mathrm{P} 1=$ 89.03(10), C17-Fe1-P2 = 89.38(10), C17-Fe1-N1 = 89.63(12), $\mathrm{C} 17-\mathrm{Fe} 1-\mathrm{C} 25=92.81(12), \mathrm{C} 17-\mathrm{N} 2-\mathrm{C} 18=175.7(3), \mathrm{C} 25-\mathrm{N} 3-\mathrm{C} 26$ 179.7(3).

\section{Catalytic studies in alcohol acceptorless dehydrogenation}

Complexes 3a-c were further assessed in base-free dehydrogenative coupling of $n$-butanol into butyl butyrate. As a comparison, the carbonyl $\left[\mathrm{Ru}(\mathrm{H})\left(\mathrm{BH}_{4}\right)(\mathrm{CO})\left(\mathrm{PNP}^{\mathrm{H}}\right)\right]$ derivative was also evaluated under identical catalytic conditions. $\mathrm{TON}_{\max }$ (maximal turnover number) and $\mathrm{TOF}_{0}$ (initial turnover frequency) values were summarized in Table 1. It is worth noting that the cationic iron complex 9 is inactive for conversion of $n$-butanol into ester. Comparative kinetic profiles of $n$-butanol conversion into ester are presented on Figure 12. Interestingly, complexes $\mathbf{3 a}\left(\mathrm{TOF}_{0}=6220 \mathrm{~h}^{-1}\right)$ and $\mathbf{3 b}$ $\left(\mathrm{TOF}_{0}=5970 \mathrm{~h}^{-1}\right)$ bearing respectively benzyl and $n$-butyl isonitrile were found to be initially more active than the benchmark carbonyl complex $\left(\mathrm{TOF}_{0}=4300 \mathrm{~h}^{-1}\right)$. However, the latter is catalytically more robust: Its corresponding $\mathrm{TON}_{\max }$ value (14100) is higher than that of 3a (10200) and 3b (9000). These isonitrile adducts reach a plateau after about 3 hours of reaction, which may indicate catalyst deactivation. On the other hand, the $t \mathrm{Bu}$ isonitrile derivative reaches its deactivated regime after about one hour, totaling about 2900 TON. These reactivity patterns illustrate that the substitution of the carbonyl by the isonitrile ligand has a beneficial effect. Catalytic behavior is indeed modulated by the nature of the isonitrile substituent. However, it seems that this type of ligand is not inert under these reaction conditions, which severely compromises its use in such a context. Thus, according to $\mathrm{TOF}_{0}$ and 
$\mathrm{TON}_{\max }$ values, the catalytic activity and robustness can be classified as follows: for catalytic activity, $\mathbf{3 a} \approx \mathbf{3} \mathbf{b}>$ $\left[\mathrm{Ru}(\mathrm{H})\left(\mathrm{BH}_{4}\right)(\mathrm{CO})\left(\mathrm{PNP}^{\mathrm{H}}\right)\right] \quad>\quad \mathbf{3 c} ;$ for robustness, $\left[\mathrm{Ru}(\mathrm{H})\left(\mathrm{BH}_{4}\right)(\mathrm{CO})\left(\mathrm{PNP}^{\mathrm{H}}\right)\right]>\mathbf{3 a}>\mathbf{3 b}>>\mathbf{3 c}$. Considering that the bulky $t$-butyl group is rather remote from the metal center, it is doubtfull that the lowest catalytic performance of $\mathbf{3 c}$ is related to steric effects. The origin of this behavior should be found in the more donating character of the $t$-butyl-substituted isonitrile.

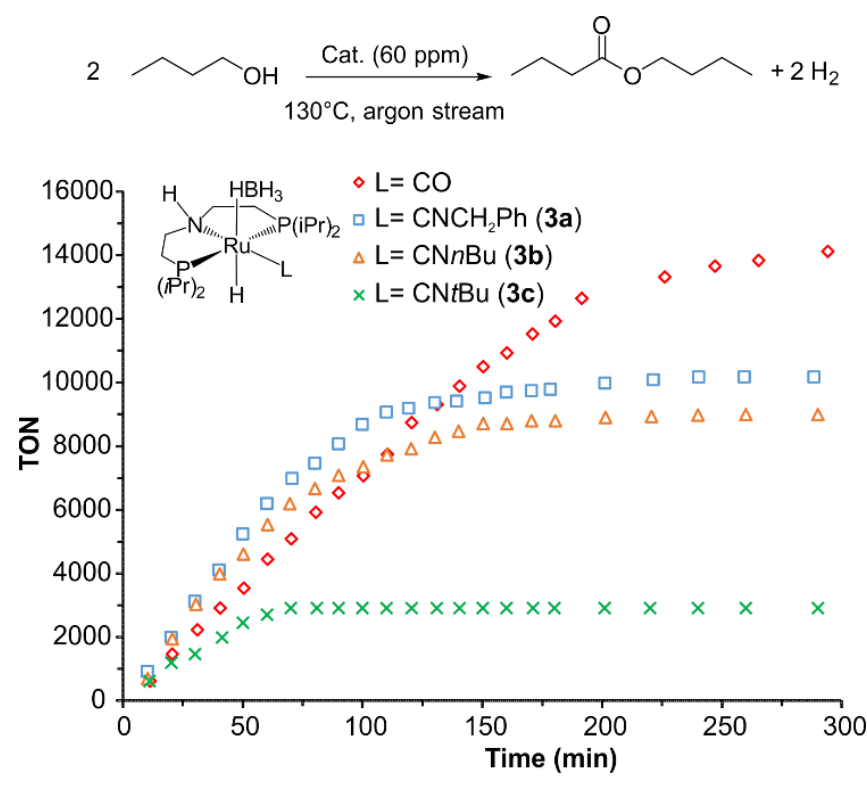

Figure 12. Comparative kinetic profiles of butanol conversion mediated by Ru PNP complexes. Conditions: Ru loading $=60$ ppm, T $=130{ }^{\circ} \mathrm{C}$.

Table 1. $\mathrm{TON}_{\max }$ and $\mathrm{TOF}^{\circ}$ values for butanol conversion to butyl butyrate.

\begin{tabular}{|c|c|c|c|}
\hline Complexes & $\mathbf{T O F}^{\circ}\left(\mathbf{h}^{\mathbf{- 1}}\right)$ & TON & $\begin{array}{c}\text { Conversion } \\
(\boldsymbol{\%})^{\mathbf{a}}\end{array}$ \\
\hline 3a & 6220 & 10200 & 61 \\
\hline 3b & 5970 & 9000 & 54 \\
\hline 3c & 2930 & 2900 & 17 \\
\hline$\left[\mathrm{Ru}(\mathrm{H})\left(\mathrm{BH}_{4}\right)(\mathrm{CO})\left(\mathrm{PNP}^{\mathrm{H}}\right)\right]$ & 4300 & 14100 & 85 \\
\hline 9c & 0 & 0 & 0 \\
\hline
\end{tabular}

Conditions : Ru loading $=60 \mathrm{ppm}, \mathrm{T}=130^{\circ} \mathrm{C}$. a : measured by ${ }^{1} \mathrm{H}$ NMR

The lesser robustness of the isonitrile derivatives compared to that of their carbonyl counterpart may be ascribed at this stage to known reactivity patterns of isonitrile ligands. As reviewed recently, ${ }^{29}$ transition metal-bound isonitrile are prone to react with nucleophiles, to afford Fischer carbene species resulting from attack of the alcohol onto the carbon center (Scheme 4, top reaction). This has been recently observed by Mezetti in a related context (ironmediated transfer hydrogenation of ketones using a secondary alcohol as hydrogen source), though basic conditions were required for the carbene formation to proceed. ${ }^{30}$ As alkoxide species of the type $\left[\mathrm{Ru}\left(\mathrm{PNP}^{\mathrm{H}}\right)(\mathrm{OR})(\mathrm{H})(\mathrm{CNR})\right]$ are most likely formed and involved in the catalytic cycle for alcohol dehydrogenative coupling, as in the case of carbonyl-based systems, ${ }^{16 \mathrm{~d}}$ one may also envision an intramolecular deactivation pathway to access such carbene species. Alternatively, when investigating iron isonitrile complexes as catalysts for ketones transfer hydrogenation, Reiser and coworkers have also proposed that an intermediate iron hydride moiety reacts with isonitrile ligand, affording iminoformyl species ${ }^{31}$, similar to hydride migratory insertion into a carbonyl to form a acyl group. Such reaction scheme was also reported by Duckett, when studying the reactivity of ruthenium isonitrile hydride complexes. ${ }^{32}$ This could be operative on intermediate $\left[\mathrm{Ru}\left(\mathrm{PNP}^{\mathrm{H}}\right)(\mathrm{H})_{2}(\mathrm{CNR})\right]$, which proved to be unstable.

The corresponding reaction pathway in the present case would result in the formation of hydride-free species (Scheme 4, middle reaction). The kinetic profile recorded for the $t$-butylisonitrile precatalyst (Figure 12) hints at a behavior different from that of its benzyl and $n$-butyl counterparts, reaching a plateau after about 90 minutes and thus achieving less than 3000 turnover numbers. As reported by Walton and Jones, complexes featuring this specific ligand can thermally decompose into cyanide derivatives, with release of isobutene or isobutane. ${ }^{33}$ In the present case, this would result in $[\mathrm{Ru}(\mathrm{PNP})(\mathrm{CN})(\mathrm{X})]$ (Scheme 4, bottom reaction). The occurrence of these three potential catalyst decomposition pathways will be probed in future specifically dedicated studies.

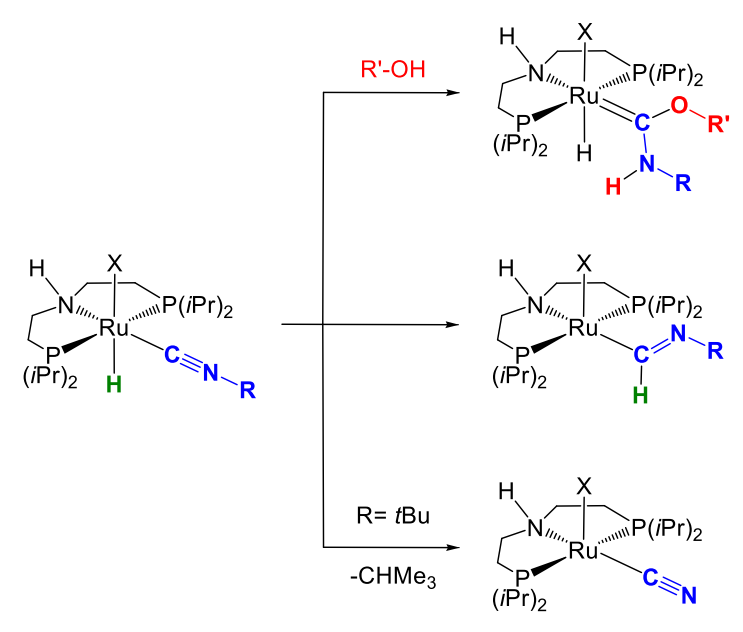

Scheme 4. Plausible decomposition pathways for ruthenium isonitrile derivatives.

\section{Conclusions}

A series of neutral and cationic ruthenium and iron aliphatic PNPtype pincer complexes bearing benzyl, $n$-butyl or tert-butyl isocyanides as ancillary ligands have been prepared. Their structure was investigated notably by multinuclear NMR spectroscopy, as well as by single crystal X-ray diffraction studies. Borohydride ruthenium isonitrile complexes, structurally similar to the benchmark $\mathrm{Ru}$ MACHO-BH carbonyl derivative, were catalytically evaluated for base-free acceptorless dehydrogenative coupling reactions (ADC) of butanol. Catalytic activities were found to be related to the nature of isonitrile bound to the metal center, as shown by kinetic followup. Although their intial catalytic activity is better or comparable to that of the carbonyl parent compound, the robustness of [Ru]CNR bond may be compromised under catalytic reaction conditions, undergoing decomposition to afford inactive species. While these results with isonitrile-containing systems bring positive elements for catalytic activity improvement of Ru PNP systems, the future implementation of this class of ancillary ligands is bound to 
the understanding of the deactivation pattern(s), and to the possibility to shut down such pathway(s). This will be the focus of future studies.

\section{Experimental Section}

All experiments were carried out under argon atmosphere using a glovebox or a vacuum line using standard Schlenk techniques unless some special conditions are pointed out. All ruthenium and iron complexes and tridentate ligands were stored under argon. $\left[\mathrm{Ru}(\mathrm{Cl})(\mu-\mathrm{Cl})\left(\mathrm{PNP}^{\mathrm{H}}\right)\right]_{2}{ }^{17}$ and $\left[\mathrm{FeBr}_{2}\left(\mathrm{PNP}^{\mathrm{H}}\right)\right]^{6 \mathrm{~d}, 34}$ were prepared according to literature procedures. ${ }^{1} \mathrm{H},{ }^{13} \mathrm{P},{ }^{13} \mathrm{C},{ }^{15} \mathrm{~N}$ and ${ }^{11} \mathrm{~B}$ NMR spectra were recorded at $300 \mathrm{~K}$ on a Bruker Avance 300 and 400 NMR spectrometers. ${ }^{1} \mathrm{H}$ and ${ }^{13} \mathrm{C}$ NMR chemical shifts are reported in $\mathrm{ppm}(\delta)$ downfield from tetramethylsilane. ${ }^{31} \mathrm{P}$ NMR chemical shifts are reported in ppm $(\delta)$ downfield from $\mathrm{H}_{3} \mathrm{PO}_{4} .{ }^{15} \mathrm{~N}$ NMR chemical shift are reported in ppm $(\delta)$ downfield from $\mathrm{NH}_{3}$, and were indirectly determined from 2D ${ }^{1} \mathrm{H}-{ }^{15} \mathrm{~N}$ HMBC/HSQC. ${ }^{11} \mathrm{~B}$ NMR chemical shift are reported in ppm $(\delta)$ downfield from $\mathrm{BF}_{3} . \mathrm{Et}_{2} \mathrm{O}$. Common abbreviations used in the NMR experiments are as follows: s singlet (s), doublet (d), triplet (t), virtual triplet (vt), quartet (q), quintet (qt), multiplet (m). IR spectra were recorded on a Nicolet 6700 FT-IR spectrometer equipped with a Praying Mantis mirror chamber (from Harrick Scientific) by using a DRIFT cell equipped with $\mathrm{KBr}$ windows. The samples were prepared under argon in a glove-box. Typically, 64 scans were accumulated for each spectrum (resolution $4 \mathrm{~cm}^{-1}$ ). Data are reported as follows: weak (w), medium (m), strong (s) and very strong (vs).

$\left[\mathbf{R u}(\mathbf{C l})_{2}\left(\mathbf{C N}-\mathbf{C H}_{2} \mathbf{P h}\right)\left(\mathbf{P N P}^{\mathbf{H}}\right)\right](\mathbf{1 a})$. To the yellow-orange suspension of dimeric $\left[\mathrm{Ru}(\mathrm{Cl})(\mu-\mathrm{Cl})\left(\mathrm{PNP}^{\mathrm{H}}\right)\right]_{2}$ complex $(1.38 \mathrm{~g}, 1.45$ $\mathrm{mmol})$ in THF $(50 \mathrm{~mL})$ was added dropwise a solution of benzyl isocyanide (2.1 equiv., $0.35 \mathrm{~mL})$ in THF $(10 \mathrm{~mL})$ at room temperature. The mixture was stirred for $14 \mathrm{~h}$ at RT, affording an off-white suspension. The reaction mixture was evaporated under reduced pressure to give an off-white solid, which was further washed with small amounts of $\mathrm{CH}_{2} \mathrm{Cl}_{2}$ at $0^{\circ} \mathrm{C}(5 \times 3 \mathrm{~mL})$ and then with $n$-pentane $(3 \times 20 \mathrm{~mL})$ and finally dried under high vacuum. Yield: $1.35 \mathrm{~g}$, 78\%. Anal. Calcd. for $\mathrm{C}_{24} \mathrm{H}_{44} \mathrm{Cl}_{2} \mathrm{~N}_{2} \mathrm{P}_{2} \mathrm{Ru}$ : C 48.48; $\mathrm{H} 7.46 ; \mathrm{N} 4.71$. Found: C 48.32; H 7.37; N 4.64. FT-IR $\left(\mathrm{cm}^{-1}\right): 3133$ (s, v $\left.v_{\mathrm{N}-\mathrm{H}}\right), 2105$ (vs, $\left.v_{\mathrm{C} \equiv \mathrm{N}}\right) .{ }^{1} \mathrm{H}$ NMR $\left(298 \mathrm{~K}, \mathrm{CD}_{2} \mathrm{Cl}_{2}, 400.33 \mathrm{MHz}, \mathrm{ppm}\right): \delta 7.45-$ 7.26 (m, 5H, $\left.\mathrm{C}_{\mathrm{Ar}} \mathrm{H}, \mathrm{PhCH}_{2} \mathrm{NC}\right), 4.88$ (s, 2H, $\left.\mathrm{PhCH}_{2} \mathrm{NC}\right), 3.19$ (m, CH $i \mathrm{Pr}$ ), 3.01 (m, $\left.2 \mathrm{H}, \mathrm{CH}_{2} \mathrm{PNP}\right), 2.66$ (m, $\left.2 \mathrm{H}, \mathrm{CH}_{2} \mathrm{PNP}\right), 2.54$ (t, $1 \mathrm{H},{ }^{3} J_{\mathrm{HH}}=11.4 \mathrm{~Hz}, \mathrm{NH}$ PNP), $2.38(\mathrm{~m}, \mathrm{CH} i \mathrm{Pr}), 2.24\left(\mathrm{~m}, 2 \mathrm{H}, \mathrm{CH}_{2}\right.$ PNP), $1.51\left(\mathrm{dt}, 6 \mathrm{H}, J_{\mathrm{HH}}=7.1 \mathrm{~Hz}, J_{\mathrm{HP}}=7.4 \mathrm{~Hz}, \mathrm{CH}_{3} i \mathrm{Pr}\right) 1.47$ (dt, $\left.6 \mathrm{H}, J_{\mathrm{HH}}=7.3 \mathrm{~Hz}, J_{\mathrm{HP}}=7.4 \mathrm{~Hz}, \mathrm{CH}_{3} i \mathrm{Pr}\right), 1.40\left(\mathrm{dt}, 6 \mathrm{H}, J_{\mathrm{HH}}=7.0\right.$ $\left.\mathrm{Hz}, J_{\mathrm{HP}}=7.4 \mathrm{~Hz}, \mathrm{CH}_{3} i \mathrm{Pr}\right), 1.36\left(\mathrm{dt}, 6 \mathrm{H}, J_{\mathrm{HH}}=6.9 \mathrm{~Hz}, J_{\mathrm{HP}}=6.5\right.$ $\left.\mathrm{Hz}, \mathrm{CH}_{3} i \mathrm{Pr}\right), 1.30\left(\mathrm{dt}, 6 \mathrm{H}, J_{\mathrm{HH}}=6.8 \mathrm{~Hz}, J_{\mathrm{HP}}=6.9 \mathrm{~Hz}, \mathrm{CH}_{3} i \mathrm{Pr}\right)$, 1.23 (m, 2H, $\left.\mathrm{CH}_{2} \mathrm{PNP}\right) .{ }^{13} \mathrm{C}\left\{{ }^{1} \mathrm{H}\right\}$ NMR $\left(298 \mathrm{~K}, \mathrm{CD}_{2} \mathrm{Cl}_{2}, 100.663\right.$ MHz, ppm): $\delta$ 56.1, 51.4 ( $\left.\mathrm{CH}_{2} \mathrm{PNP}\right), 49.3\left(\mathrm{CH}_{2}, \mathrm{PhCH}_{2} \mathrm{NC}\right), 29.2$ ( $\mathrm{CH} i \mathrm{Pr}), 28.0,27.0\left(\mathrm{CH}_{2} \mathrm{PNP}\right), 25.2$, $23.0(\mathrm{CH} i \mathrm{Pr}), 19.9$, 19.7, $19.0\left(\mathrm{CH}_{3} i \mathrm{Pr}\right) .{ }^{31} \mathrm{P}\left\{{ }^{1} \mathrm{H}\right\}$ NMR $\left(298 \mathrm{~K}, \mathrm{CD}_{2} \mathrm{Cl}_{2}, 162.057 \mathrm{MHz}\right.$, ppm): $\delta$ 42.37. 2D $\left\{{ }^{1} \mathrm{H}^{-15} \mathrm{~N}\right\}$ HSQC NMR $\left(298 \mathrm{~K}, \mathrm{CD}_{2} \mathrm{Cl}_{2}, 40.565\right.$ MHz, ppm): $\delta 19.1$ (NH PNP). $2 \mathrm{D}\left\{{ }^{15} \mathrm{~N}-{ }^{1} \mathrm{H}\right\}$ HMBC NMR $(298 \mathrm{~K}$, $\left.\mathrm{CD}_{2} \mathrm{Cl}_{2}, 40.565 \mathrm{MHz}, \mathrm{ppm}\right): \delta 164.1\left(\mathrm{PhCH}_{2} N \mathrm{C}\right)$.

$\left[\mathbf{R u}(\mathbf{C l})_{2}(\mathbf{C N}-\boldsymbol{n B u})\left(\mathbf{P N P}^{\mathbf{H}}\right)\right](\mathbf{1 b})$. The complex was prepared in a similar manner to the procedure described above for $\mathbf{1 a}$. Yield: 1.38 g, 85\%. Anal. Calcd. for $\mathrm{C}_{21} \mathrm{H}_{46} \mathrm{Cl}_{2} \mathrm{~N}_{2} \mathrm{P}_{2} \mathrm{Ru}$ : C 45.00; $\mathrm{H} 8.27 ; \mathrm{N}$ 5.00. Found: C 45.16; H 8.63; N 5.14. FT-IR $\left(\mathrm{cm}^{-1}\right)$ : $3146\left(\mathrm{~s}, \mathrm{v}_{\mathrm{N}-\mathrm{H}}\right)$, 2101 (vs, $\left.v_{\mathrm{C} \equiv \mathrm{N}}\right) .{ }^{1} \mathrm{H}$ NMR $\left(293 \mathrm{~K}, \mathrm{CD}_{2} \mathrm{Cl}_{2}, 400.33 \mathrm{MHz}, \mathrm{ppm}\right): \delta$ $3.68\left(\mathrm{t}, 2 \mathrm{H},{ }^{3} J_{\mathrm{HH}}=6.8 \mathrm{~Hz}, \mathrm{CNCH}_{2}\left(\mathrm{CH}_{2}\right)_{2} \mathrm{CH}_{3}\right), 3.21\left(\mathrm{~m}, 2 \mathrm{H}, J_{\mathrm{HH}}=\right.$ $7.3 \mathrm{~Hz}, \mathrm{CH} i \mathrm{Pr}$ ), 2.98 (m, 2H, CH $2 \mathrm{PNP}$ ), 2.75-2.52 (m, 3H, $\mathrm{CH}_{2}$ PNP and NH), 2.45 (m, 2H, CH $i \mathrm{Pr}), 2.25$ (m, 2H, $\left.\mathrm{CH}_{2} \mathrm{PNP}\right), 1.62$ (m, 2H, $\left.\quad \mathrm{CN}-\mathrm{CH}_{2} \mathrm{CH}_{2} \mathrm{CH}_{2} \mathrm{CH}_{3}\right), \quad 1.55-1.21 \quad(\mathrm{~m}, \quad 4 \mathrm{H}, \quad \mathrm{CN}-$ $\left(\mathrm{CH}_{2}\right)_{2} \mathrm{CH}_{2} \mathrm{CH}_{3}$ and $\left.\mathrm{CH}_{2} \mathrm{PNP}\right), 1.51\left(\mathrm{~m}, 6 \mathrm{H}, \mathrm{CH}_{3} \mathrm{Pr}\right), 1.49(\mathrm{~m}, 6 \mathrm{H}$, $\left.\mathrm{CH}_{3} i \mathrm{Pr}\right), 1.38\left(\mathrm{~m}, 6 \mathrm{H}, \mathrm{CH}_{3} i \mathrm{Pr}\right), 1.36\left(\mathrm{~m}, 6 \mathrm{H}, \mathrm{CH}_{3} i \mathrm{Pr}\right), 0.93(\mathrm{t}, 3 \mathrm{H}$, $\left.J_{\mathrm{HH}}=7.3 \mathrm{~Hz}, \mathrm{CN}\left(\mathrm{CH}_{2}\right)_{3} \mathrm{CH}_{3}\right) .{ }^{31} \mathrm{P}\left\{{ }^{1} \mathrm{H}\right\} \mathrm{NMR}\left(298 \mathrm{~K}, \mathrm{CD}_{2} \mathrm{Cl}_{2}\right.$, $162.057 \mathrm{MHz}, \mathrm{ppm}): \delta 42.76$ (PNP). ${ }^{13} \mathrm{C}\left\{{ }^{1} \mathrm{H}\right\} \mathrm{NMR}\left(298 \mathrm{~K}, \mathrm{C}_{6} \mathrm{D}_{6}\right.$,
$100.663 \mathrm{MHz}, \mathrm{ppm}): \delta 51.6\left(\mathrm{t}, J_{\mathrm{CP}}=2.9 \mathrm{~Hz}, \mathrm{CH}_{2} \mathrm{PNP}\right), 45.6$ $\left(\mathrm{CNCH}_{2}\left(\mathrm{CH}_{2}\right)_{2} \mathrm{CH}_{3}\right), 33.2\left(\mathrm{CH}_{2}\right), 29.04\left(\mathrm{~d}, J_{\mathrm{CP}}=10 \mathrm{~Hz}, \mathrm{CH} i \mathrm{Pr}\right)$, $28.3\left(\mathrm{t}, J_{\mathrm{CP}}=8.7 \mathrm{~Hz}, \mathrm{CH}_{2} \mathrm{PNP}\right), 23.09\left(\mathrm{~d}, 2 \mathrm{C}, J_{\mathrm{CP}}=8.9 \mathrm{~Hz}, \mathrm{CH}\right.$ $i \mathrm{Pr}), \quad 20.4\left(\mathrm{CH}_{2}\right), \quad 20.3, \quad 20.2, \quad 20.1, \quad 19.3 \quad\left(\mathrm{CH}_{3} \quad i \mathrm{Pr}\right), \quad 14.3$ $\left(\mathrm{CNCH}_{2}\left(\mathrm{CH}_{2}\right)_{2} \mathrm{CH}_{3}\right) .2 \mathrm{D}\left\{{ }^{15} \mathrm{~N}-{ }^{1} \mathrm{H}\right\}$ HSQC NMR $\left(298 \mathrm{~K}, \mathrm{CD}_{2} \mathrm{Cl}_{2}\right.$, $40.565 \mathrm{MHz}, \mathrm{ppm}): \delta 18.5$ (NH PNP). $2 \mathrm{D}\left\{{ }^{15} \mathrm{~N}-{ }^{1} \mathrm{H}\right\}$ HMBC NMR

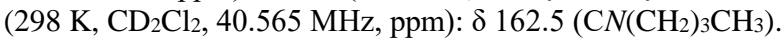

$\left[\mathbf{R u}(\mathbf{C l})_{2}(\mathbf{C N}-t \mathbf{B u})\left(\mathbf{P N P}^{\mathbf{H}}\right)\right](\mathbf{1 c})$. The complex was prepared in a similar manner to the procedure described above, though with a reaction time of 48 hours. Yield: $1.33 \mathrm{~g}, 82 \%$. Anal. Calcd. for $\mathrm{C}_{21} \mathrm{H}_{46} \mathrm{Cl}_{2} \mathrm{~N}_{2} \mathrm{P}_{2} \mathrm{Ru}$ : C 45.00; $\mathrm{H}$ 8.27; N 5.00. Found: C 44.92; $\mathrm{H}$ 8.29; N 4.95. FT-IR $\left(\mathrm{cm}^{-1}\right): 3148\left(\mathrm{~s}, v_{\mathrm{NH}}\right), 2102\left(\mathrm{~s}, v_{\mathrm{C}=\mathrm{N}}\right) .{ }^{1} \mathrm{H}$ NMR $\left(298 \mathrm{~K}, \mathrm{CD}_{2} \mathrm{Cl}_{2}, 400.33 \mathrm{MHz}, \mathrm{ppm}\right): \delta 3.19\left(\mathrm{~m}, 2 \mathrm{H}, J_{\mathrm{HH}}=7.3 \mathrm{~Hz}\right.$, $\left.J_{\mathrm{HP}}=3.6 \mathrm{~Hz}, \mathrm{CH} i \mathrm{Pr}\right), 2.99\left(\mathrm{~m}, 2 \mathrm{H}, J_{\mathrm{HH}}=11.8,3.3 \mathrm{~Hz}, \mathrm{CH}_{2} \mathrm{PNP}\right)$, $2.66\left(\mathrm{~m}, 2 \mathrm{H}, \mathrm{CH}_{2} \mathrm{PNP}\right), 2.52(\mathrm{~m}, 2 \mathrm{H}, \mathrm{CH} i \mathrm{Pr}), 2.47\left(1 \mathrm{H}, \mathrm{t},{ }^{3} J_{\mathrm{HH}}=\right.$ $12.2 \mathrm{~Hz}, \mathrm{NH}), 2.30\left(\mathrm{~m}, 2 \mathrm{H}, J_{\mathrm{HH}}=14.6,2.4 \mathrm{~Hz}, J_{\mathrm{HP}}=4.4 \mathrm{~Hz}, \mathrm{CH}_{2}\right.$ PNP), $1.56\left(\mathrm{~m}, 6 \mathrm{H}, J_{\mathrm{HH}}=7.4 \mathrm{~Hz}, J_{\mathrm{HP}}=7.4 \mathrm{~Hz}, \mathrm{CH}_{3} i \mathrm{Pr}\right), 1.53(\mathrm{~m}$, $\left.6 \mathrm{H}, J_{\mathrm{HH}}=7.4 \mathrm{~Hz}, J_{\mathrm{HP}}=7.4 \mathrm{~Hz}, \mathrm{CH}_{3} i \mathrm{Pr}\right), 1.42\left(\mathrm{~s}, 9 \mathrm{H}, \mathrm{CH}_{3} t \mathrm{Bu}\right)$, $1.40\left(\mathrm{~m}, 6 \mathrm{H}, J_{\mathrm{HH}}=7.3 \mathrm{~Hz}, J_{\mathrm{HP}}=6.3 \mathrm{~Hz}, \mathrm{CH}_{3} i \mathrm{Pr}\right), 1.37\left(\mathrm{~m}, 6 \mathrm{H}, J_{\mathrm{HH}}\right.$ $\left.=7.2 \mathrm{~Hz}, J_{\mathrm{HP}}=6.1 \mathrm{~Hz}, \mathrm{CH}_{3} i \mathrm{Pr}\right), 1.22\left(\mathrm{~m}, 2 \mathrm{H}, J_{\mathrm{HH}}=14.9,5.5 \mathrm{~Hz}\right.$, $\left.J_{\mathrm{HP}}=1.9 \mathrm{~Hz}, \mathrm{CH}_{2} \mathrm{PNP}\right) .{ }^{31} \mathrm{P}\left\{{ }^{1} \mathrm{H}\right\} \mathrm{NMR}\left(298 \mathrm{~K}, \mathrm{CD}_{2} \mathrm{Cl}_{2}, 162.057\right.$ $\mathrm{MHz}, \mathrm{ppm}): \delta 42.06$ (PNP). ${ }^{13} \mathrm{C}\left\{{ }^{1} \mathrm{H}\right\} \mathrm{NMR}\left(298 \mathrm{~K}, \mathrm{CD}_{2} \mathrm{Cl}_{2}\right.$, $100.663 \mathrm{MHz}, \mathrm{ppm}): \delta 51.27$ (t, $\left.J_{\mathrm{CP}}=2.9 \mathrm{~Hz}, \mathrm{CH}_{2} \mathrm{PNP}\right), 31.75(\mathrm{~s}$, $\left.\mathrm{CH}_{3} t \mathrm{Bu}\right), 29.80\left(\mathrm{t}, J_{\mathrm{CP}}=10.4 \mathrm{~Hz}, \mathrm{CH} i \mathrm{Pr}\right), 28.35\left(\mathrm{t}, J_{\mathrm{CP}}=8.8 \mathrm{~Hz}\right.$, $\left.\mathrm{CH}_{2} \mathrm{PNP}\right), 22.93$ (t, $\left.J_{\mathrm{CP}}=7.9 \mathrm{~Hz}, \mathrm{CH} i \mathrm{Pr}\right), 20.18\left(\mathrm{CH}_{3} i \mathrm{Pr}\right), 19.90$ $\left(\mathrm{CH}_{3} i \mathrm{Pr}\right), 19.49\left(\mathrm{CH}_{3} i \mathrm{Pr}\right), 19.44\left(\mathrm{CH}_{3} i \mathrm{Pr}\right) .2 \mathrm{D}\left\{{ }^{15} \mathrm{~N}-{ }^{1} \mathrm{H}\right\}$ HSQC NMR (298 K, $\left.\mathrm{CD}_{2} \mathrm{Cl}_{2}, 40.565 \mathrm{MHz}, \mathrm{ppm}\right): \delta 19.1$ (NH, PNP). 2D $\left\{{ }^{15} \mathrm{~N}^{-1} \mathrm{H}\right\}$ HMBC NMR $\left(298 \mathrm{~K}, \mathrm{CD}_{2} \mathrm{Cl}_{2}, 40.565 \mathrm{MHz}, \mathrm{ppm}\right): \delta$ $187.7(\mathrm{CN}-\mathrm{Bu})$.

$\left[\mathbf{R u}(\mathrm{Cl})\left(\mathbf{C N}-\mathrm{CH}_{2} \mathbf{P h}\right)_{2}\left(\mathbf{P N P H}^{\mathrm{H}}\right)\right](\mathbf{C l})(\mathbf{2 a})$. To a yellow-orange solution of dimeric $\left[\mathrm{Ru}(\mathrm{Cl})(\mu-\mathrm{Cl})\left(\mathrm{PNP}^{\mathrm{H}}\right)\right]_{2}$ complex $(1.0 \mathrm{~g}, 1.05 \mathrm{mmol})$ in $\mathrm{CH}_{2} \mathrm{Cl}_{2}(50 \mathrm{~mL})$ was added dropwise a solution of benzyl isocyanide (5.6 equiv.) in $\mathrm{CH}_{2} \mathrm{Cl}_{2}(10 \mathrm{~mL})$ at room temperature. The reaction mixture immediately turns to green. After stirring for $20 \mathrm{~h}$ at $\mathrm{RT}$, a pale yellow suspension was obtained. The reaction mixture was evaporated to dryness. The obtained residual solid was washed with diethyl ether $(3 \times 5 \mathrm{~mL})$ and $n$-pentane $(3 \times 5 \mathrm{~mL})$ and dried under vacuum. The product was further purified by crystallization into $\mathrm{CH}_{2} \mathrm{Cl}_{2} /$ diethyl ether at $-20^{\circ} \mathrm{C}$ as a white solid. Yield: $1.08 \mathrm{~g}$, $72 \%$. The complex can also be synthesized by using THF as solvent. Anal. Calcd. for $\mathrm{C}_{32} \mathrm{H}_{51} \mathrm{Cl}_{2} \mathrm{~N}_{3} \mathrm{P}_{2} \mathrm{Ru}$ : C 54.01; H 7.22; N 5.90. Found: C 54.2; H 7.91; N 6.10. FT-IR ( $\left.\mathrm{cm}^{-1}\right)$ : 3062 (m, vNH), 2140 (vs, v $\mathrm{C} \equiv \mathrm{N}) .{ }^{1} \mathrm{H}$ NMR $\left(298 \mathrm{~K}, \mathrm{CD}_{2} \mathrm{Cl}_{2}, 400.33 \mathrm{MHz}, \mathrm{ppm}\right): \delta 7.69$ (m, 2H, $\left.\mathrm{C}_{\mathrm{Ar}}-\mathrm{H}, \mathrm{Ph}\right), 7.46-7.31\left(\mathrm{~m}, 8 \mathrm{H}, \mathrm{C}_{\mathrm{Ar}}-\mathrm{H}, \mathrm{Ph}\right), 6.91$ (br t, $1 \mathrm{H}$, $\left.J_{\mathrm{HH}}=9.8 \mathrm{~Hz}, \mathrm{NH}\right), 5.15\left(\mathrm{~s}, 2 \mathrm{H}, \mathrm{CH}_{2} \mathrm{Ph}\right), 4.90\left(\mathrm{~s}, 2 \mathrm{H}, \mathrm{CH}_{2} \mathrm{Ph}\right), 3.02$ (m, 2H, $\mathrm{CH}_{2} \mathrm{PNP}$ ), 2.33 (m, 2H, CH $i \mathrm{Pr}$ ), 2.30 (m, 2H, CH $i \mathrm{Pr}$ ), 2.06 (m, 2H, $\left.\mathrm{CH}_{2} \mathrm{PNP}\right), 1.95$ (m, 2H, $\left.\mathrm{CH}_{2} \mathrm{PNP}\right), 1.83$ (m, 2H, $\mathrm{CH}_{2}$ PNP), 1.28 (m, 6H, CH $\left.\mathrm{CH}_{3} \mathrm{Pr}\right), 1.27$ (m, 6H, $\left.J_{\mathrm{HH}}=7.3 \mathrm{~Hz},-\mathrm{CH}_{3}, i \mathrm{Pr}\right)$, $1.26\left(\mathrm{~m}, 6 \mathrm{H}, \mathrm{CH}_{3} i \mathrm{Pr}\right), 1.15\left(\mathrm{td}, 6 \mathrm{H}, J_{\mathrm{HH}}=7.1 \mathrm{~Hz}, J_{\mathrm{HP}}=6.9 \mathrm{~Hz}\right.$, $\left.\mathrm{CH}_{3} i \mathrm{Pr}\right) .{ }^{31} \mathrm{P}\left\{{ }^{1} \mathrm{H}\right\}$ NMR $\left(298 \mathrm{~K}, \mathrm{CD}_{2} \mathrm{Cl}_{2}, 121.495 \mathrm{MHz}, \mathrm{ppm}\right): \delta$ 48.77 (PNP). ${ }^{13} \mathrm{C}\left\{{ }^{1} \mathrm{H}\right\}$ NMR (298 K, $\left.\mathrm{CD}_{2} \mathrm{Cl}_{2}, 100.663 \mathrm{MHz}, \mathrm{ppm}\right)$ : $\delta 135.50$ ( $\mathrm{C}_{\mathrm{Ar}}$ quat., $\left.\mathrm{Ph}\right), 132.93\left(\mathrm{C}_{\mathrm{Ar}}\right.$ quat., $\left.\mathrm{Ph}\right), 129.58\left(\mathrm{C}_{\mathrm{Ar}}-\mathrm{H}, \mathrm{Ph}\right)$, 129.31 ( $\left.\mathrm{C}_{\mathrm{Ar}}-\mathrm{H}, \mathrm{Ph}\right), 129.25\left(\mathrm{C}_{\mathrm{Ar}}-\mathrm{H}, \mathrm{Ph}\right), 128.89$ ( $\left.\mathrm{C}_{\mathrm{Ar}}-\mathrm{H}, \mathrm{Ph}\right), 128.10$ $\left(\mathrm{C}_{\mathrm{Ar}}-\mathrm{H}, \mathrm{Ph}\right), 56.17\left(\mathrm{CH}_{2} \mathrm{PNP}\right), 49.29\left(\mathrm{CH}_{2} \mathrm{Ph}\right), 49.13\left(\mathrm{CH}_{2} \mathrm{Ph}\right)$, $30.68\left(\mathrm{t}, J_{\mathrm{CP}}=11.8 \mathrm{~Hz}, \mathrm{CH}_{2} \mathrm{PNP}\right), 28.11\left(\mathrm{t}, 2 \mathrm{C}, J_{\mathrm{CP}}=11.1 \mathrm{~Hz}, \mathrm{CH}\right.$ $i \mathrm{Pr}), 26.12\left(\mathrm{t}, J_{\mathrm{CP}}=8.9 \mathrm{~Hz}, \mathrm{CH} i \mathrm{Pr}\right), 19.88\left(\mathrm{CH}_{3} i \mathrm{Pr}\right), 19.52\left(\mathrm{CH}_{3}\right.$ $i \mathrm{Pr}), 19.20\left(\mathrm{CH}_{3} i \mathrm{Pr}\right), 19.17\left(\mathrm{CH}_{3} i \mathrm{Pr}\right) .2 \mathrm{D}\left\{{ }^{1} \mathrm{H}^{13}{ }^{13} \mathrm{C}\right\} \mathrm{HMBC}$ NMR $\left(298 \mathrm{~K}, \mathrm{CD}_{2} \mathrm{Cl}_{2}, 100.663 \mathrm{MHz}\right): 160.0,153.5\left(\mathrm{CN}-\mathrm{CH}_{2} \mathrm{Ph}\right) .2 \mathrm{D}$ $\left\{{ }^{15} \mathrm{~N}-{ }^{1} \mathrm{H}\right\}$ HSQC NMR $\left(298 \mathrm{~K}, \mathrm{CD}_{2} \mathrm{Cl}_{2}, 40.565 \mathrm{MHz}, \mathrm{ppm}\right): \delta$ 16.37 (NH, PNP). 2D $\left\{{ }^{15} \mathrm{~N}-{ }^{1} \mathrm{H}\right\}$ HMBC NMR (293K, $\mathrm{CD}_{2} \mathrm{Cl}_{2}$, $40.565 \mathrm{MHz}, \mathrm{ppm}): \delta 173.91\left(\mathrm{CNCH}_{2} \mathrm{Ph}\right), 171.37\left(\mathrm{CNCH}_{2} \mathrm{Ph}\right)$.

$\left.\left[\mathbf{R u}(\mathbf{C l})(\mathbf{C N}-\boldsymbol{n B u})_{2}\left(\mathbf{P N P}^{\mathrm{H}}\right)\right](\mathbf{C l}) \mathbf{( 2 b}\right)$. The complex was prepared in a similar manner to the procedure described above for $\mathbf{2 a}$. Yield: $69 \%$. Anal. Calcd. for $\mathrm{C}_{26} \mathrm{H}_{55} \mathrm{Cl}_{2} \mathrm{~N}_{3} \mathrm{P}_{2} \mathrm{Ru}$ : C 48.52; $\mathrm{H}$ 8.61; N 6.53. Found: C 48.63; H 9.25; N 7.08. ${ }^{1} \mathrm{H}$ NMR (298 K, $\mathrm{C}_{6} \mathrm{D}_{6}, 400.33$ $\mathrm{MHz}, \mathrm{ppm}): \delta 8.45$ (br t, $\left.1 \mathrm{H}, J_{\mathrm{HH}}=10 \mathrm{~Hz}, \mathrm{NH}\right), 3.79\left(\mathrm{t}, 2 \mathrm{H}, J_{\mathrm{HH}}=\right.$ 
$\left.6.9 \mathrm{~Hz}, \mathrm{CNCH}_{2}\left(\mathrm{CH}_{2}\right)_{2} \mathrm{CH}_{3}\right), 3.04$ (m, 2H, $\left.\mathrm{CH}_{2} \mathrm{PNP}\right), 2.92$ (t, $2 \mathrm{H}$, $\left.J_{\mathrm{HH}}=6.4 \mathrm{~Hz}, \mathrm{CNCH}_{2}\left(\mathrm{CH}_{2}\right)_{2} \mathrm{CH}_{3}\right), 2.71(\mathrm{~m}, 2 \mathrm{H}, \mathrm{CH} i \mathrm{Pr}), 2.41(\mathrm{~m}$, $\left.2 \mathrm{H}, \mathrm{CH}_{2}, J_{\mathrm{HH}}=5.6,14.3 \mathrm{~Hz}\right), 2.22(\mathrm{~m}, 2 \mathrm{H}, \mathrm{CH} i \mathrm{Pr}), 1.71\left(2 \mathrm{H}, \mathrm{CH}_{2}\right)$, $1.69\left(\mathrm{td}, 6 \mathrm{H}, J_{\mathrm{HH}}=7.3 \mathrm{~Hz}, J_{\mathrm{HP}}=7.6 \mathrm{~Hz}, \mathrm{CH}_{3} i \operatorname{Pr}\right), 1.63-1.49(4 \mathrm{H}$, $\left.\mathrm{CH}_{2}\right), 1.31\left(\mathrm{t}, 6 \mathrm{H}, J_{\mathrm{HH}}=7.1 \mathrm{~Hz}, \mathrm{CH}_{3} i \mathrm{Pr}\right), 1.28\left(\mathrm{~m}, 6 \mathrm{H}, \mathrm{CH}_{3} i \mathrm{Pr}\right)$, $1.25\left(\mathrm{~m}, 6 \mathrm{H}, \mathrm{CH}_{3} i \mathrm{Pr}\right), 1.22-1.06\left(\mathrm{~m}, 8 \mathrm{H}, \mathrm{CH}_{2}\right), 0.77\left(\mathrm{t}, 3 \mathrm{H}, J_{\mathrm{HH}}=\right.$ $\left.7.3 \mathrm{~Hz}, \mathrm{CNCH}_{2}\left(\mathrm{CH}_{2}\right)_{2} \mathrm{CH}_{3}\right), 0.67\left(\mathrm{t}, 3 \mathrm{H}, J_{\mathrm{HH}}=7.1 \mathrm{~Hz}\right.$, $\left.\mathrm{CNCH}_{2}\left(\mathrm{CH}_{2}\right)_{2} \mathrm{CH}_{3}\right) .{ }^{31} \mathrm{P}\left\{{ }^{1} \mathrm{H}\right\}$ NMR $\left(298 \mathrm{~K}, \mathrm{C}_{6} \mathrm{D}_{6}, 121.495 \mathrm{MHz}\right.$, ppm): $\delta 49.9$ (PNP). ${ }^{13} \mathrm{C}\left\{{ }^{1} \mathrm{H}\right\}$ NMR $\left(298 \mathrm{~K}, \mathrm{C}_{6} \mathrm{D}_{6}, 100.663 \mathrm{MHz}\right.$, ppm): $\delta 55.94\left(\mathrm{CH}_{2} \mathrm{PNP}\right), 44.98\left(\mathrm{CH}_{2}, n \mathrm{Bu}\right), 44.70\left(\mathrm{CH}_{2} n \mathrm{Bu}\right)$, $31.38\left(\mathrm{CH}_{2} n \mathrm{Bu}\right), 30.97\left(\mathrm{CH}_{2} n \mathrm{Bu}\right), 30.38\left(\mathrm{t}, J_{\mathrm{CP}}=11.3 \mathrm{~Hz}, \mathrm{CH}\right.$ $i \mathrm{Pr}), 27.92\left(\mathrm{t}, J_{\mathrm{CP}}=10.4 \mathrm{~Hz}, \mathrm{CH}_{2} \mathrm{PNP}\right), 25.90\left(\mathrm{t}, J_{\mathrm{CP}}=9.3 \mathrm{~Hz}, \mathrm{CH}\right.$ $i$ Pr), $20.06\left(\mathrm{CH}_{2} n \mathrm{Bu}\right), 19.98\left(\mathrm{CH}_{2} n \mathrm{Bu}\right), 19.86\left(\mathrm{CH}_{3} i \mathrm{Pr}\right), 19.58$ $\left(\mathrm{CH}_{3} i \mathrm{Pr}\right), 19.20\left(\mathrm{CH}_{3} i \mathrm{Pr}\right), 13.36\left(\mathrm{CH}_{3} n \mathrm{Bu}\right), 13.21\left(\mathrm{CH}_{3}, n \mathrm{Bu}\right)$. $2 \mathrm{D}\left\{{ }^{15} \mathrm{~N}-{ }^{1} \mathrm{H}\right\}$ HSQC NMR $\left(298 \mathrm{~K}, \mathrm{C}_{6} \mathrm{D}_{6}, 40.565 \mathrm{MHz}, \mathrm{ppm}\right): \delta$ 17.8 (NH, PNP). 2D $\left\{{ }^{15} \mathrm{~N}-{ }^{1} \mathrm{H}\right\}$ HMBC NMR $\left(298 \mathrm{~K}, \mathrm{C}_{6} \mathrm{D}_{6}, 40.565\right.$ MHz, ppm): $\delta$ 176.0, $171.8\left(\mathrm{CN}\left(\mathrm{CH}_{2}\right)_{3} \mathrm{CH}_{3}\right)$.

$\left[\mathbf{R u}(\mathbf{C l})(\mathbf{C N}-t \mathbf{B u})_{2}\left(\mathbf{P N P}^{\mathbf{H}}\right)\right] \mathbf{C l}(\mathbf{2 c})$. The complex was prepared in a similar manner to the procedure described above for $\mathbf{2 a}$. Yield: 75\%. Anal. Calcd. for $\mathrm{C}_{26} \mathrm{H}_{55} \mathrm{Cl}_{2} \mathrm{~N}_{3} \mathrm{P}_{2} \mathrm{Ru}$ : C 48.52; $\mathrm{H}$ 8.61; N 6.53. Found: C 48.63; H 9.25; N 7.08. ${ }^{1} \mathrm{H}$ NMR $\left(300 \mathrm{~K}, \mathrm{CD}_{2} \mathrm{Cl}_{2}, 400.33\right.$ $\mathrm{MHz}, \mathrm{ppm}): \delta 6.74$ (br t, $\left.1 \mathrm{H}, J_{\mathrm{HH}}=10.4 \mathrm{~Hz}, \mathrm{NH} \mathrm{PNP}\right), 3.03(\mathrm{~m}$, $2 \mathrm{H}, \mathrm{CH}_{2} \mathrm{PNP}$ ), 2.60 (m, 2H, CH $i \mathrm{Pr}$ ), 2.50 (m, 2H, CH $\left.i \mathrm{Pr}\right), 2.15$ (m, 2H, $\left.\mathrm{CH}_{2} \mathrm{PNP}\right), 1.92\left(\mathrm{~m}, 2 \mathrm{H}, \mathrm{CH}_{2} \mathrm{PNP}\right), 1.8$ (m, 2H, $\left.\mathrm{CH}_{2} \mathrm{PNP}\right)$, $1.56\left(\mathrm{~s}, 9 \mathrm{H}, \mathrm{CH}_{3} t \mathrm{Bu}\right), 1.53\left(\mathrm{~m}, 6 \mathrm{H}, \mathrm{CH}_{3} i \mathrm{Pr}\right), 1.49\left(\mathrm{~m}, 6 \mathrm{H}, \mathrm{CH}_{3}\right.$ $i \mathrm{Pr}), 1.48\left(\mathrm{~s}, 9 \mathrm{H}, \mathrm{CH}_{3} t \mathrm{Bu}\right), 1.41\left(\mathrm{dt}, 6 \mathrm{H}, J_{\mathrm{HH}}=7.5 \mathrm{~Hz}, J_{\mathrm{HP}}=6.9\right.$ $\left.\mathrm{Hz}, \mathrm{CH}_{3} i \mathrm{Pr}\right), 1.34\left(\mathrm{dt}, 6 \mathrm{H}, \mathrm{CH}_{3}, J_{\mathrm{HH}}=7.5 \mathrm{~Hz}, J_{\mathrm{HP}}=6.9 \mathrm{~Hz}, \mathrm{CH}_{3}\right.$ $i \mathrm{Pr}) .{ }^{31} \mathrm{P}\left\{{ }^{1} \mathrm{H}\right\}$ NMR $\left(300 \mathrm{~K}, \mathrm{CD}_{2} \mathrm{Cl}_{2}, 400.33 \mathrm{MHz}, \mathrm{ppm}\right): \delta 49.07$ (PNP). ${ }^{13} \mathrm{C}\left\{{ }^{1} \mathrm{H}\right\}$ NMR $\left(300 \mathrm{~K}, \mathrm{CD}_{2} \mathrm{Cl}_{2}, 100.663 \mathrm{MHz}, \mathrm{ppm}\right): \delta$ 57.53 (d, C quat. $t \mathrm{Bu}), 57.40(\mathrm{~d}, \mathrm{C}$ quat. $t \mathrm{Bu}), 55.62\left(\mathrm{CH}_{2} \mathrm{PNP}\right)$, $30.90\left(\mathrm{t}, J_{\mathrm{CP}}=11.4 \mathrm{~Hz}, \mathrm{CH} i \mathrm{Pr}\right), 30.55\left(\mathrm{CH}_{3} t \mathrm{Bu}\right), 30.21\left(\mathrm{CH}_{3} t \mathrm{Bu}\right)$, $27.79\left(\mathrm{t}, J_{\mathrm{CP}}=10.8 \mathrm{~Hz}, \mathrm{CH}_{2} \mathrm{PNP}\right), 26.63\left(\mathrm{t}, J_{\mathrm{CP}}=9.6 \mathrm{~Hz}, \mathrm{CH} i \mathrm{Pr}\right.$ ), $20.09\left(\mathrm{CH}_{3} i \mathrm{Pr}\right), 19.88\left(\mathrm{CH}_{3} i \mathrm{Pr}\right), 19.54\left(\mathrm{CH}_{3} i \mathrm{Pr}\right) .2 \mathrm{D}\left\{{ }^{15} \mathrm{~N}-{ }^{1} \mathrm{H}\right\}$ HSQC NMR $\left(300 \mathrm{~K}, \mathrm{CD}_{2} \mathrm{Cl}_{2}, 40.565 \mathrm{MHz}, \mathrm{ppm}\right): \delta 14.7(\mathrm{NH}$ PNP). 2D $\left\{{ }^{15} \mathrm{~N}-{ }^{1} \mathrm{H}\right\}$ HMBC NMR $\left(300 \mathrm{~K}, \mathrm{CD}_{2} \mathrm{Cl}_{2}, 40.565 \mathrm{MHz}\right.$, ppm): $\delta 194.2(\mathrm{CN}-t \mathrm{Bu})$.

$\left[\mathbf{R u}(\mathbf{H})\left(\mathbf{B H}_{4}\right)\left(\mathbf{C N}-\mathbf{C H}_{2} \mathbf{P h}\right)\left(\mathbf{P N P}^{\mathbf{H}}\right)\right](\mathbf{3 a})$. To the suspension of $\mathbf{1 a}$ $(0.5 \mathrm{~g}, 0.84 \mathrm{mmol})$ in $\mathrm{EtOH}(50 \mathrm{~mL})$ was added $\mathrm{NaBH}_{4}$ (5-10 equiv.) at RT. The reaction mixture was stirred at RT for $20 \mathrm{~h}$. The resulting colorless solution was evaporated to dryness under reduced pressure. The residual white solids were extracted with toluene $(2 \times 30 \mathrm{~mL})$. The extracts were filtered and evaporated to dryness. Yield: $0.31 \mathrm{~g}, 67 \%$. Anal. Calcd. for $\mathrm{C}_{24} \mathrm{H}_{49} \mathrm{BN}_{2} \mathrm{P}_{2} \mathrm{Ru}$ : C 53.43; $\mathrm{H}$ 9.16; N 5.19. Found C 54.13; H 9.43; N 5.19. ${ }^{1} \mathrm{H}$ NMR (298 K, $\left.\mathrm{C}_{6} \mathrm{D}_{6}, 400.33 \mathrm{MHz}, \mathrm{ppm}\right): \delta$ 7.21-7.09 (m, 4H, $\left.\mathrm{C}_{\mathrm{Ar}}-\mathrm{H}, \mathrm{Ph}\right), 7.02$ (t, $1 \mathrm{H}, J_{\mathrm{HH}}=7.1 \mathrm{~Hz}$, para- $\left.\mathrm{C}_{\mathrm{Ar}}-\mathrm{H}, \mathrm{Ph}\right), 4.32\left(\mathrm{~s}, 2 \mathrm{H}, \mathrm{CH}_{2} \mathrm{Ph}\right), 3.98(\mathrm{br} \mathrm{t}$, $\left.1 \mathrm{H}, J_{\mathrm{HN}}=11.1 \mathrm{~Hz}, \mathrm{NH}\right), 2.80(\mathrm{~m}, 2 \mathrm{H}, \mathrm{CH} i \mathrm{Pr}), 2.54\left(\mathrm{~m}, 2 \mathrm{H}, \mathrm{CH}_{2}\right.$ PNP), 1.92 (m, 2H, CH $i \mathrm{Pr}$ ), 1.82-1.56 (m, 6H, CH $2 \mathrm{PNP}$ ), 1.50 (dt, $\left.J_{\mathrm{HH}}=7.4 \mathrm{~Hz}, J_{\mathrm{HP}}=7.5 \mathrm{~Hz}, 6 \mathrm{H}, \mathrm{CH}_{3} i \mathrm{Pr}\right), 1.13\left(\mathrm{dt}, J_{\mathrm{HH}}=7.0 \mathrm{~Hz}\right.$, $\left.J_{\mathrm{HP}}=6.7 \mathrm{~Hz}, 12 \mathrm{H}, \mathrm{CH}_{3} i \mathrm{Pr}\right), 1.02\left(\mathrm{dt}, J_{\mathrm{HH}}=6.9 \mathrm{~Hz}, J_{\mathrm{HP}}=6.9 \mathrm{~Hz}\right.$, $\left.6 \mathrm{H}, \mathrm{CH}_{3} i \mathrm{Pr}\right),-1.50$ (br d, $\left.4 \mathrm{H}, \mathrm{BH}_{4}\right),-14.33\left(\mathrm{t},{ }^{2} J_{\mathrm{HP}}=18.4 \mathrm{~Hz}, 1 \mathrm{H}\right.$, $\mathrm{Ru}-\mathrm{H}) .{ }^{31} \mathrm{P}\left\{{ }^{1} \mathrm{H}\right\}$ NMR (298 K, $\left.\mathrm{C}_{6} \mathrm{D}_{6}, 121.495 \mathrm{MHz}, \mathrm{ppm}\right): \delta 77.57$ (PNP). ${ }^{13} \mathrm{C}\left\{{ }^{1} \mathrm{H}\right\}$ NMR $\left(298 \mathrm{~K}, \mathrm{C}_{6} \mathrm{D}_{6}, 100.663 \mathrm{MHz}, \mathrm{ppm}\right): \delta 137.19$ $\left(\mathrm{CH}_{2} C_{\mathrm{Ar}}\right), 128.79,127.58,127.17\left(\mathrm{C}_{\mathrm{Ar}}-\mathrm{H}\right), 54.56\left(\mathrm{t}, J_{\mathrm{CP}}=5.3 \mathrm{~Hz}\right.$, $\left.\mathrm{CH}_{2} \mathrm{PNP}\right), 48.14\left(\mathrm{CH}_{2} \mathrm{Ph}\right), 30.01$ (t, $2 \mathrm{C}, J_{\mathrm{CP}}=8.3 \mathrm{~Hz}, \mathrm{CH}_{2} \mathrm{PNP}$ ), $29.02\left(\mathrm{t},{ }^{1} J_{\mathrm{CP}}=10.2 \mathrm{~Hz}, \mathrm{CH} i \mathrm{Pr}\right), 24.46\left(\mathrm{t},{ }^{1} J_{\mathrm{CP}}=11.7 \mathrm{~Hz}, \mathrm{CH} i \mathrm{Pr}\right)$, $21.31\left(\mathrm{t},{ }^{2} J_{\mathrm{CP}}=3.6 \mathrm{~Hz}, \mathrm{CH}_{3} i \mathrm{Pr}\right), 20.82\left(\mathrm{t},{ }^{2} J_{\mathrm{CP}}=3.6 \mathrm{~Hz}, \mathrm{CH}_{3} i \mathrm{Pr}\right)$, $19.1\left(\mathrm{CH}_{3} i \mathrm{Pr}\right), 18.08\left(\mathrm{CH}_{3} i \mathrm{Pr}\right) .2 \mathrm{D}\left\{{ }^{15} \mathrm{~N}-{ }^{1} \mathrm{H}\right\} \mathrm{HSQC}$ NMR $(293 \mathrm{~K}$, $\left.\mathrm{C}_{6} \mathrm{D}_{6}, 40.565 \mathrm{MHz}, \mathrm{ppm}\right): \delta 47.3(\mathrm{NH}) .2 \mathrm{D}\left\{{ }^{15} \mathrm{~N}-{ }^{1} \mathrm{H}\right\}$ HMBC NMR $\left(293 \mathrm{~K}, \mathrm{C}_{6} \mathrm{D}_{6}, 40.565 \mathrm{MHz}, \mathrm{ppm}\right): \delta 160.04\left(\mathrm{CNCH}_{2} \mathrm{Ph}\right) .{ }^{11} \mathrm{~B}\left\{{ }^{1} \mathrm{H}\right\}$ NMR (293 K, C6 $\left.\mathrm{D}_{6}, 128.442 \mathrm{MHz}, \mathrm{ppm}\right)$ : $\delta$-33.46 (br, $\mathrm{BH}_{4}$ ).

$\left.\left[\mathbf{R u}(\mathbf{H})\left(\mathbf{B H}_{4}\right)(\mathbf{C N}-\boldsymbol{n} \mathbf{B u})\left(\mathbf{P N P}^{\mathbf{H}}\right)\right] \mathbf{( 3 b}\right)$. The complex was prepared in a similar manner to the procedure described above for 3a. Yield: 69\%. Anal. Calcd. for $\mathrm{C}_{21} \mathrm{H}_{51} \mathrm{BN}_{2} \mathrm{P}_{2} \mathrm{Ru}$ : C 49.90; $\mathrm{H} 10.17$; N 5.54. Found: C 50.04; H 10.26; N 5.68. ${ }^{1} \mathrm{H}$ NMR $\left(298 \mathrm{~K}, \mathrm{C}_{7} \mathrm{D}_{8}, 400.33\right.$ $\mathrm{MHz}, \mathrm{ppm}): \delta 3.92$ (br, $1 \mathrm{H}, \mathrm{NH}), 3.07\left(\mathrm{t}, 2 \mathrm{H},{ }^{3} J_{\mathrm{HH}}=6.5 \mathrm{~Hz}, \mathrm{CN}-\right.$
$\mathrm{CH}_{2}$ ), 2.72 (m, 2H, CH $i \mathrm{Pr}$ ), 2.61 (m, 2H, $\left.\mathrm{CH}_{2} \mathrm{PNP}\right), 1.95$ (m, 2H, $\mathrm{CH} i \mathrm{Pr}), 1.8-1.57\left(\mathrm{~m}, 6 \mathrm{H}, \mathrm{CH}_{2} \mathrm{PNP}\right), 1.50\left(\mathrm{dt}, 6 \mathrm{H}, J_{\mathrm{HH}}=7.4 \mathrm{~Hz}\right.$, $\left.J_{\mathrm{HP}}=7.5 \mathrm{~Hz}, \mathrm{CH}_{3} i \mathrm{Pr}\right), 1.21\left(\mathrm{~m}, 2 \mathrm{H}, \mathrm{CH}_{2} n \mathrm{Bu}\right), 1.19-1.1(\mathrm{~m}, 14 \mathrm{H}$, $2 \mathrm{H} \mathrm{CH}_{2} n \mathrm{Bu}$ and $\left.12 \mathrm{H} \mathrm{CH}_{3} i \mathrm{Pr}\right), 1.02\left(\mathrm{dt}, J_{\mathrm{HH}}=6.9 \mathrm{~Hz}, J_{\mathrm{HP}}=6.9\right.$ $\left.\mathrm{Hz}, 6 \mathrm{H}, \mathrm{CH}_{3} i \mathrm{Pr}\right), 0.74\left(\mathrm{t},{ }^{3} J_{\mathrm{HH}}=7.1 \mathrm{~Hz}, 3 \mathrm{H}, \mathrm{CH}_{3} n \mathrm{Bu}\right),-1.80(\mathrm{br}$, $\left.4 \mathrm{H}, \mathrm{BH}_{4}\right),-14.67\left(\mathrm{t},{ }^{2} J_{\mathrm{HP}}=18.8 \mathrm{~Hz}, 1 \mathrm{H}, \mathrm{Ru}-\mathrm{H}\right) .{ }^{31} \mathrm{P}\left\{{ }^{1} \mathrm{H}\right\} \mathrm{NMR}(298$ $\left.\mathrm{K}, \mathrm{C}_{7} \mathrm{D}_{8}, 121.495 \mathrm{MHz}, \mathrm{ppm}\right): \delta 77.73$ (PNP). ${ }^{13} \mathrm{C}\left\{{ }^{1} \mathrm{H}\right\} \mathrm{NMR}(298$ $\left.\mathrm{K}, \mathrm{C}_{7} \mathrm{D}_{8}, 75.468 \mathrm{MHz}, \mathrm{ppm}\right): \delta 176.68\left(\mathrm{t},{ }^{2} J_{\mathrm{CP}}=12.8 \mathrm{~Hz}, \mathrm{CN}-n \mathrm{Bu}\right)$, $54.2\left(\mathrm{t}, J_{\mathrm{CP}}=4.3 \mathrm{~Hz}, \mathrm{CH}_{2} \mathrm{PNP}\right), 43.57\left(\mathrm{CN}-\mathrm{CH}_{2}\right), 32.63\left(\mathrm{CH}_{2}\right.$ $n \mathrm{Bu}), 29.94\left(\mathrm{t}, J_{\mathrm{CP}}=8.4 \mathrm{~Hz}, \mathrm{CH}_{2} \mathrm{PNP}\right), 28.90\left(\mathrm{t}, J_{\mathrm{CP}}=10 \mathrm{~Hz}, \mathrm{CH}\right.$ $i \mathrm{Pr}), 24.5$ (t, $\left.J_{\mathrm{CP}}=11.5 \mathrm{~Hz}, \mathrm{CH} i \mathrm{Pr}\right), 21.15\left(\mathrm{CH}_{3} i \mathrm{Pr}\right), 20.59\left(\mathrm{CH}_{3}\right.$ $i \mathrm{Pr}), 19.87\left(\mathrm{CH}_{2} n \mathrm{Bu}\right), 18.94\left(\mathrm{CH}_{3} i \mathrm{Pr}\right), 17.92\left(\mathrm{CH}_{3} i \mathrm{Pr}\right), 13.33$ $\left(\mathrm{CH}_{3} n \mathrm{Bu}\right) .2 \mathrm{D}\left\{{ }^{15} \mathrm{~N}-{ }^{1} \mathrm{H}\right\}$ HSQC NMR $\left(293 \mathrm{~K}, \mathrm{C}_{7} \mathrm{D}_{8}, 40.565 \mathrm{MHz}\right.$, ppm): $\delta 44.6(\mathrm{NH}, \mathrm{PNP}) .2 \mathrm{D}\left\{{ }^{15} \mathrm{~N}-{ }^{1} \mathrm{H}\right\}$ HMBC NMR $\left(298 \mathrm{~K}, \mathrm{C}_{7} \mathrm{D}_{8}\right.$, $40.565 \mathrm{MHz}, \mathrm{ppm}): \delta 163.02(\mathrm{CN}-n \mathrm{Bu}) .{ }^{11} \mathrm{~B}\left\{{ }^{1} \mathrm{H}\right\} \mathrm{NMR}(298 \mathrm{~K}$, $\left.\mathrm{C}_{7} \mathrm{D}_{8}, 128.442 \mathrm{MHz}, \mathrm{ppm}\right): \delta-33.99\left(\mathrm{br}, \mathrm{BH}_{4}\right)$.

$\left.\left[\mathbf{R u}(\mathbf{H})\left(\mathbf{B H}_{4}\right)(\mathbf{C N}-\boldsymbol{t} \mathbf{B u})\left(\mathbf{P N P} \mathbf{H}^{\mathbf{H}}\right)\right] \mathbf{( 3 c}\right)$. The complex was prepared in a similar manner to the procedure described above for 3a. Yield: 73\%. Anal. Calcd. for $\mathrm{C}_{21} \mathrm{H}_{51} \mathrm{BN}_{2} \mathrm{P}_{2} \mathrm{Ru}$ : C 49.90; $\mathrm{H} 10.17$; N 5.54. Found: C 50.02; H 10.07; N 5.60. FT-IR $\left(v, \mathrm{~cm}^{-1}\right)$ : 3206.9 (w, NH), 2371, 2327.4 (vs), $2298\left(\mathrm{Ru}_{-} \mathrm{HBH}_{3}\right), 2024.2$ (vs, Ru-CN), 1837.2 (m, Ru-H). ${ }^{1} \mathrm{H}$ NMR (298 K, C7 $\left.\mathrm{D}_{8}, 400.33 \mathrm{MHz}, \mathrm{ppm}\right): \delta 3.89$ (br, $1 \mathrm{H}, \mathrm{NH}), 2.75$ (m, 2H, CH $i \mathrm{Pr}$ ), 2.51 (m, 2H, $\left.\mathrm{CH}_{2} \mathrm{PNP}\right), 1.97$ (m, $2 \mathrm{H}, \mathrm{CH} i \mathrm{Pr}), 1.72-1.56\left(\mathrm{~m}, 6 \mathrm{H}, \mathrm{CH}_{2} \mathrm{PNP}\right), 1.52\left(\mathrm{dt}, 6 \mathrm{H}, J_{\mathrm{HH}}=7.4\right.$ $\left.\mathrm{Hz}, J_{\mathrm{HP}}=7.5 \mathrm{~Hz}, \mathrm{CH}_{3} i \mathrm{Pr}\right), 1.15\left(\mathrm{dt}, 12 \mathrm{H}, J_{\mathrm{HH}}=7.0 \mathrm{~Hz}, J_{\mathrm{HP}}=6.5\right.$ $\left.\mathrm{Hz}, \mathrm{CH}_{3} i \mathrm{Pr}\right), 1.09\left(\mathrm{~s}, 9 \mathrm{H}, \mathrm{CH}_{3} t \mathrm{Bu}\right), 1.02\left(\mathrm{dt}, J_{\mathrm{HH}}=6.8 \mathrm{~Hz}, J_{\mathrm{HP}}=\right.$ $\left.6.8 \mathrm{~Hz}, 6 \mathrm{H}, \mathrm{CH}_{3} i \mathrm{Pr}\right),-1.31\left(\mathrm{br}, 4 \mathrm{H}, \mathrm{BH}_{4}\right),-14.78\left(\mathrm{t},{ }^{2} J_{\mathrm{HP}}=18.6 \mathrm{~Hz}\right.$, $1 \mathrm{H}, \mathrm{Ru}-\mathrm{H}) .{ }^{31} \mathrm{P}\left\{{ }^{1} \mathrm{H}\right\} \mathrm{NMR}\left(298 \mathrm{~K}, \mathrm{C}_{7} \mathrm{D}_{8}, 121.495 \mathrm{MHz}, \mathrm{ppm}\right): \delta$ 77.32 (PNP). ${ }^{13} \mathrm{C}\left\{{ }^{1} \mathrm{H}_{-}{ }^{31} \mathrm{P}\right\}$ NMR $\left(298 \mathrm{~K}, \mathrm{C}_{7} \mathrm{D} 8,100.663 \mathrm{MHz}\right.$, ppm): $\delta 169(C \mathrm{~N}-t \mathrm{Bu}), 54.7\left(\mathrm{C}_{\text {quat. }} t \mathrm{Bu}\right), 54.4\left(\mathrm{CH}_{2} \mathrm{PNP}\right), 31.0\left(\mathrm{CH}_{3}\right.$ $t \mathrm{Bu}), 30.1\left(\mathrm{CH}_{2} \mathrm{PNP}\right), 29.4(\mathrm{CH} i \mathrm{Pr}), 24.9(\mathrm{CH} i \mathrm{Pr}), 21.4\left(\mathrm{CH}_{3} i \mathrm{Pr}\right)$, $20.7\left(\mathrm{CH}_{3} i \mathrm{Pr}\right), 19.1\left(\mathrm{CH}_{3} i \mathrm{Pr}\right), 17.9\left(\mathrm{CH}_{3} i \mathrm{Pr}\right) .2 \mathrm{D}\left\{{ }^{1} \mathrm{H}^{-13} \mathrm{C}\right\} \mathrm{HMBC}$ NMR (298 K, C $\left.7 \mathrm{D}_{8}, 100.663 \mathrm{MHz}, \mathrm{ppm}\right): 169(C \mathrm{~N}-t \mathrm{Bu}) .2 \mathrm{D}\left\{{ }^{15} \mathrm{~N}-\right.$ ${ }^{1} \mathrm{H}$ \} HSQC NMR (298 K, $\left.\mathrm{C}_{7} \mathrm{D}_{8}, 40.565 \mathrm{MHz}, \mathrm{ppm}\right): \delta 47.0(\mathrm{NH})$. 2D $\left\{{ }^{15} \mathrm{~N}-{ }^{1} \mathrm{H}\right\}$ HMBC NMR $\left(298 \mathrm{~K}, \mathrm{C}_{7} \mathrm{D}_{8}, 40.565 \mathrm{MHz}, \mathrm{ppm}\right): \delta$ 184.61 $(\mathrm{CN}-t \mathrm{Bu}) .{ }^{11} \mathrm{~B}\left\{{ }^{1} \mathrm{H}\right\}$ NMR $\left(298 \mathrm{~K}, \mathrm{C}_{7} \mathrm{D}_{8}, 128.4418 \mathrm{MHz}\right.$, ppm): $\delta-33.86$ (br, $\left.1 \mathrm{~B}, \mathrm{BH}_{4}\right)$.

$\left[\mathbf{R u}(\mathrm{H})(\mathbf{C l})\left(\mathbf{C N}-\mathrm{CH}_{2} \mathbf{P h}\right)\left(\mathbf{P N P}^{\mathrm{H}}\right)\right]$ (4a). To the suspension of $1 \mathrm{a}$ $(0.4 \mathrm{~g}, 0.67 \mathrm{mmol})$ in $\mathrm{EtOH}(40 \mathrm{~mL})$ was slowly added the solution of $\mathrm{NaBH}_{4}(1$ equiv., $0.026 \mathrm{~g})$ in $\mathrm{EtOH}(10 \mathrm{~mL})$ at $0^{\circ} \mathrm{C}$. The reaction mixture was stirred at RT for $20 \mathrm{~h}$. The resulting colorless solution was evaporated to dryness under reduced pressure. The residual white solids were extracted with toluene and the solution was filtered and concentrated. The crystallization process was performed by addition of $n$-pentane while maintaining the solution at $-20^{\circ} \mathrm{C}$. After 20h, white crystals formed and were collected and washed with $n$-pentane $(3 \times 5 \mathrm{~mL})$ and dried under vacuum. Yield: $0.22 \mathrm{~g}$, $59 \%$. Anal. Calcd. for $\mathrm{C}_{24} \mathrm{H}_{45} \mathrm{ClN}_{2} \mathrm{P}_{2} \mathrm{Ru}$ : C 51.47; $\mathrm{H}$ 8.10; N 5.00. Found: C 51.48; H 8.26; N 5.06. ${ }^{1} \mathrm{H}$ NMR (298 K, $\mathrm{C}_{6} \mathrm{D}_{6}, 400.33$ $\mathrm{MHz}, \mathrm{ppm}): \delta 7.33\left(\mathrm{~d},{ }^{3} J_{\mathrm{HH}}=7.5 \mathrm{~Hz}, 2 \mathrm{H}\right.$, ortho- $\left.\mathrm{C}_{\mathrm{Ar}}-\mathrm{H}\right), 7.17(\mathrm{t}$, ${ }^{3} J_{\mathrm{HH}}=8.0 \mathrm{~Hz}$, meta- $\left.\mathrm{C} \mathrm{Ar}-\mathrm{H}\right), 7.05\left(\mathrm{t},{ }^{3} J_{\mathrm{HH}}=7.3 \mathrm{~Hz}, 1 \mathrm{H}\right.$, para- $\mathrm{C}_{\mathrm{Ar}}-$ $\mathrm{H}, \mathrm{Ph}), 4.52\left(\mathrm{~s}, 2 \mathrm{H}, \mathrm{CH}_{2} \mathrm{Ph}\right), 3.55$ (br t, $\left.{ }^{3} J_{\mathrm{HH}}=12.0 \mathrm{~Hz}, 1 \mathrm{H}, \mathrm{NH}\right)$, $3.02(\mathrm{~m}, 2 \mathrm{H}, \mathrm{CH} i \mathrm{Pr}), 2.58\left(\mathrm{~m}, 2 \mathrm{H}, \mathrm{CH}_{2} \mathrm{PNP}\right), 1.94\left(\mathrm{~m}, 2 \mathrm{H}, J_{\mathrm{HH}}=\right.$ $6.8 \mathrm{~Hz}, \mathrm{CH} i \mathrm{Pr}), 1.81$ (m, 2H, $\left.\mathrm{CH}_{2} \mathrm{PNP}\right), 1.71-1.50\left(\mathrm{~m}, 4 \mathrm{H}, \mathrm{CH}_{2}\right.$ PNP), $1.62\left(\mathrm{dt}, J_{\mathrm{HH}}=7.4 \mathrm{~Hz}, J_{\mathrm{HP}}=7.6 \mathrm{~Hz}, 6 \mathrm{H}, \mathrm{CH}_{3} i \operatorname{Pr}\right), 1.19(\mathrm{dt}$, $\left.J_{\mathrm{HH}}=6.4 \mathrm{~Hz}, J_{\mathrm{HP}}=7.8 \mathrm{~Hz}, 6 \mathrm{H}, \mathrm{CH}_{3} i \mathrm{Pr}\right), 1.17\left(\mathrm{dt}, J_{\mathrm{HH}}=6.4 \mathrm{~Hz}\right.$, $\left.J_{\mathrm{HP}}=5.6 \mathrm{~Hz}, 6 \mathrm{H}, \mathrm{CH}_{3} i \mathrm{Pr}\right), 1.02\left(\mathrm{dt}, J_{\mathrm{HH}}=7.0 \mathrm{~Hz}, J_{\mathrm{HP}}=6.9 \mathrm{~Hz}, 6 \mathrm{H}\right.$, $\left.\mathrm{CH}_{3} i \mathrm{Pr}\right),-17.10\left(\mathrm{t},{ }^{2} J_{\mathrm{HP}}=18.7 \mathrm{~Hz}, 1 \mathrm{H}, \mathrm{Ru}-\mathrm{H}\right) .{ }^{31} \mathrm{P}\left\{{ }^{1} \mathrm{H}\right\} \mathrm{NMR}(298$ $\left.\mathrm{K}, \mathrm{C}_{6} \mathrm{D}_{6}, 121.495 \mathrm{MHz}, \mathrm{ppm}\right): \delta 74.21$ (PNP). ${ }^{13} \mathrm{C}\left\{{ }^{1} \mathrm{H}\right\} \mathrm{NMR}(298$ $\left.\mathrm{K}, \mathrm{C}_{6} \mathrm{D}_{6}, 100.663 \mathrm{MHz}, \mathrm{ppm}\right): \delta 128.61\left(\mathrm{C}_{\mathrm{Ar}}-\mathrm{H}\right), 127.27\left(\mathrm{C}_{\mathrm{Ar}}-\mathrm{H}\right)$, $127.14\left(\mathrm{C}_{\mathrm{Ar}}-\mathrm{H}\right), 53.98\left(\mathrm{t},{ }^{2} J_{\mathrm{CP}}=4.8 \mathrm{~Hz}, \mathrm{CH}_{2} \mathrm{PNP}\right), 48.36\left(\mathrm{CH}_{2} \mathrm{Ph}\right)$, $30.43\left(\mathrm{t}, J_{\mathrm{CP}}=7.9 \mathrm{~Hz}, \mathrm{CH}_{2} \mathrm{PNP}\right), 26.81\left(\mathrm{t},{ }^{1} J_{\mathrm{CP}}=9.6 \mathrm{~Hz}, \mathrm{CH} i \mathrm{Pr}\right)$, $24.27\left(\mathrm{t},{ }^{1} J_{\mathrm{CP}}=11.4 \mathrm{~Hz}, \mathrm{CH} i \mathrm{Pr}\right), 21.33\left(\mathrm{t},{ }^{2} J_{\mathrm{CP}}=2.7 \mathrm{~Hz}, \mathrm{CH}_{3} i \mathrm{Pr}\right)$, $20.96\left(\mathrm{t},{ }^{2} J_{\mathrm{CP}}=3.7 \mathrm{~Hz}, \mathrm{CH}_{3} i \mathrm{Pr}\right), 19.23\left(\mathrm{CH}_{3} i \mathrm{Pr}\right), 17.78\left(\mathrm{CH}_{3} i \mathrm{Pr}\right)$. 2D $\left\{{ }^{15} \mathrm{~N}-{ }^{1} \mathrm{H}\right\}$ HSQC NMR (293 K, $\left.\mathrm{C}_{6} \mathrm{D}_{6}, 40.565 \mathrm{MHz}, \mathrm{ppm}\right): \delta$ 
$55.1(\mathrm{NH}) .2 \mathrm{D}\left\{{ }^{15} \mathrm{~N}-{ }^{1} \mathrm{H}\right\}$ HMBC NMR $\left(293 \mathrm{~K}, \mathrm{C}_{6} \mathrm{D}_{6}, 40.565 \mathrm{MHz}\right.$, ppm): $\delta 160.04\left(\mathrm{CNCH}_{2} \mathrm{Ph}\right)$.

$\left[\mathbf{R u}(\mathrm{H})(\mathbf{C l})(\mathbf{C N}-n \mathbf{B u})\left(\mathbf{P N P}^{\mathbf{H}}\right)\right](\mathbf{4 b})$. Complex $4 \mathrm{~b}$ was prepared in a similar manner as described for the synthesis of $\mathbf{4 a}$, starting from 1b. Yield: $55 \%$. Anal. Calcd. for $\mathrm{C}_{21} \mathrm{H}_{47} \mathrm{ClN}_{2} \mathrm{P}_{2} \mathrm{Ru}$ : C 47.95; $\mathrm{H}$ 9.01; N 5.33. Found: 47.40, H 9.72, N 4.95. FT-IR $\left(v, \mathrm{~cm}^{-1}\right): 3170.1$ $\left(\mathrm{m}, v_{\mathrm{NH}}\right), 2075,2056\left(\mathrm{vs}, v_{\mathrm{C}=\mathrm{N}}\right), 1949.3$ (s, vRuH). ${ }^{1} \mathrm{H}$ NMR $(293 \mathrm{~K}$, $\left.\mathrm{C}_{6} \mathrm{D}_{6}, 400.33 \mathrm{MHz}, \mathrm{ppm}\right): \delta 3.79$ (br t, $\left.1 \mathrm{H},{ }^{3} J_{\mathrm{HH}}=11.9 \mathrm{~Hz}, \mathrm{NH}\right)$, $3.23\left(\mathrm{t},{ }^{3} J_{\mathrm{HH}}=6.1 \mathrm{~Hz}, 2 \mathrm{H}, \mathrm{CNCH}_{2}\left(\mathrm{CH}_{2}\right)_{2} \mathrm{CH}_{3}\right), 3.04(\mathrm{~m}, 2 \mathrm{H}, \mathrm{CH}$ $i \mathrm{Pr}$ ), 2.79 (br m, 2H, $\mathrm{CH}_{2} \mathrm{PNP}$ ), 2.0 (m, 2H, CH $i \mathrm{Pr}$ ), 1.89-1.58 (m, $\left.6 \mathrm{H}, \mathrm{CH}_{2} \mathrm{PNP}\right), 1.68\left(\mathrm{td},{ }^{3} J_{\mathrm{HH}}=7.5 \mathrm{~Hz},{ }^{3} J_{\mathrm{HP}}=7.5 \mathrm{~Hz}, 6 \mathrm{H}, \mathrm{CH}_{3} i \mathrm{Pr}\right)$, 1.36-1.19 (m, 4H, $\left.\mathrm{CNCH}_{2}\left(\mathrm{CH}_{2}\right)_{2} \mathrm{CH}_{3}\right), 1.24\left(\mathrm{~m}, 12 \mathrm{H}, \mathrm{CH}_{3} i \mathrm{Pr}\right)$, $1.05\left(\mathrm{td}, 6 \mathrm{H},{ }^{3} J_{\mathrm{HH}}=7.0 \mathrm{~Hz},{ }^{3} J_{\mathrm{HP}}=7.1 \mathrm{~Hz}, \mathrm{CH}_{3} i \mathrm{Pr}\right), 0.75\left(\mathrm{t},{ }^{3} J_{\mathrm{HH}}=\right.$ $\left.7.1 \mathrm{~Hz}, 3 \mathrm{H}, \mathrm{CNCH}_{2}\left(\mathrm{CH}_{2}\right)_{2} \mathrm{CH}_{3}\right),-17.58\left(\mathrm{t},{ }^{2} J_{\mathrm{HP}}=18.9 \mathrm{~Hz}, 1 \mathrm{H}, \mathrm{Ru}-\right.$ H). ${ }^{31} \mathrm{P}\left\{{ }^{1} \mathrm{H}\right\}$ NMR $\left(298 \mathrm{~K}, \mathrm{C}_{6} \mathrm{D}_{6}, 121.495 \mathrm{MHz}, \mathrm{ppm}\right): \delta 74.54$ (PNP). ${ }^{13} \mathrm{C}\left\{{ }^{1} \mathrm{H}\right\}$ NMR $\left(298 \mathrm{~K}, \mathrm{C}_{6} \mathrm{D}_{6}, 100.663 \mathrm{MHz}, \mathrm{ppm}\right): \delta 182.37$ $\left(\mathrm{t},{ }^{1} J_{\mathrm{CP}}=11.9 \mathrm{~Hz}, \mathrm{CN}\left(\mathrm{CH}_{2}\right)_{3} \mathrm{CH}_{3}\right), 54.49\left(\mathrm{t}, J_{\mathrm{CP}}=5.8 \mathrm{~Hz}, \mathrm{CH}_{2}\right.$ PNP), $44.33\left(\mathrm{CNCH}_{2}\left(\mathrm{CH}_{2}\right)_{2} \mathrm{CH}_{3}\right), 33.40\left(\mathrm{CNCH}_{2} \mathrm{CH}_{2} \mathrm{CH}_{2} \mathrm{CH}_{3}\right)$, $30.93\left(\mathrm{t}, J_{\mathrm{CP}}=7.4 \mathrm{~Hz}, \mathrm{CH}_{2} \mathrm{PNP}\right), 27.25\left(\mathrm{t},{ }^{1} J_{\mathrm{CP}}=9.2 \mathrm{~Hz}, \mathrm{CH} i \mathrm{Pr}\right)$, $24.8\left(\mathrm{t},{ }^{1} J_{\mathrm{CP}}=11.8 \mathrm{~Hz}, \mathrm{CH} i \mathrm{Pr}\right), 21.75\left(\mathrm{t},{ }^{2} J_{\mathrm{CP}}=3 \mathrm{~Hz}, \mathrm{CH}_{3} i \mathrm{Pr}\right)$, $21.31\left(\mathrm{t},{ }^{2} J_{\mathrm{CP}}=3 \mathrm{~Hz}, \mathrm{CH}_{3} \mathrm{i} \mathrm{Pr}\right), 20.50\left(\mathrm{CN}\left(\mathrm{CH}_{2}\right)_{2} \mathrm{CH}_{2} \mathrm{CH}_{3}\right), 19.63$ $\left(\mathrm{CH}_{3} i \mathrm{Pr}\right), 18.24\left(\mathrm{CH}_{3} i \mathrm{Pr}\right), 13.94\left(\mathrm{CN}\left(\mathrm{CH}_{2}\right)_{3} \mathrm{CH}_{3}\right) .2 \mathrm{D}\left\{{ }^{15} \mathrm{~N}-{ }^{1} \mathrm{H}\right\}$ HSQC NMR (298 K, $\left.\mathrm{C}_{6} \mathrm{D}_{6}, 40.565 \mathrm{MHz}, \mathrm{ppm}\right): \delta 53.8(\mathrm{NH}) .2 \mathrm{D}$ $\left\{{ }^{15} \mathrm{~N}-{ }^{1} \mathrm{H}\right\}$ HMBC NMR $\left(298 \mathrm{~K}, \mathrm{C}_{6} \mathrm{D}_{6}, 40.565 \mathrm{MHz}, \mathrm{ppm}\right): \delta 162.5$ $(\mathrm{CN}-n \mathrm{Bu})$.

$\left[\mathbf{R u}(\mathrm{H})(\mathbf{C l})(\mathbf{C N}-t \mathbf{B u})\left(\mathbf{P N P}^{\mathrm{H}}\right)\right](\mathbf{4 c})$. Complex $4 \mathrm{c}$ was prepared in a similar manner as described for the synthesis of $\mathbf{4 a}$, starting from 1c. Yield: $62 \%$. Anal. Calcd. for $\mathrm{C}_{21} \mathrm{H}_{51} \mathrm{BN}_{2} \mathrm{P}_{2} \mathrm{Ru}$ : C 47.95; $\mathrm{H} 9.01$; N 5.33. Found: C 47.37, H 9.75, N 5.14. ${ }^{1} \mathrm{H}$ NMR (298 K, $\mathrm{C}_{7} \mathrm{D}_{8}$, $400.33 \mathrm{MHz}, \mathrm{ppm}$ ): $\delta 3.73$ (br t, $\left.J_{\mathrm{HN}}=11.7 \mathrm{~Hz}, 1 \mathrm{H}, \mathrm{NH}\right), 3.05(\mathrm{~m}$, $2 \mathrm{H}, \mathrm{CH} i \mathrm{Pr}$ ), 2.73 (m, 2H, $\left.\mathrm{CH}_{2} \mathrm{PNP}\right), 2.02$ (m, 2H, CH $i \mathrm{Pr}$ ), 1.90$1.50\left(\mathrm{~m}, 6 \mathrm{H}, \mathrm{CH}_{2} \mathrm{PNP}\right), 1.69\left(\mathrm{dt},{ }^{3} J_{\mathrm{HH}}=7.2 \mathrm{~Hz},{ }^{3} J_{\mathrm{HP}}=7.4 \mathrm{~Hz}, 6 \mathrm{H}\right.$, $\left.\mathrm{CH}_{3} i \mathrm{Pr}\right), 1.25\left(\mathrm{~m}, 6 \mathrm{H}, \mathrm{CH}_{3} i \mathrm{Pr}\right), 1.24\left(\mathrm{~m}, 6 \mathrm{H}, \mathrm{CH}_{3} i \mathrm{Pr}\right), 1.18(\mathrm{~s}$, $\left.9 \mathrm{H}, \mathrm{CH}_{3} t \mathrm{Bu}\right), 1.05\left(\mathrm{dt},{ }^{3} J_{\mathrm{HH}}=6.8 \mathrm{~Hz},{ }^{3} J_{\mathrm{HP}}=6.9 \mathrm{~Hz}, 6 \mathrm{H}, \mathrm{CH}_{3} i \mathrm{Pr}\right)$, $-17.8\left(\mathrm{t},{ }^{2} J_{\mathrm{HP}}=18.8 \mathrm{~Hz}, 1 \mathrm{H}, \mathrm{Ru}-\mathrm{H}\right) .{ }^{31} \mathrm{P}\left\{{ }^{1} \mathrm{H}\right\} \mathrm{NMR}\left(298 \mathrm{~K}, \mathrm{C}_{7} \mathrm{D}_{8}\right.$, $121.495 \mathrm{MHz}, \mathrm{ppm}): \delta 74.0$ (PNP). ${ }^{13} \mathrm{C}\left\{{ }^{1} \mathrm{H}\right\} \mathrm{NMR}\left(298 \mathrm{~K}, \mathrm{C}_{7} \mathrm{D}_{8}\right.$, $100.663 \mathrm{MHz}, \mathrm{ppm}): \delta 174.0(\mathrm{CN}-t \mathrm{Bu}), 54.59$ (C quat. $t \mathrm{Bu}), 54.22$ $\left(\mathrm{t}, J_{\mathrm{CP}}=5.0 \mathrm{~Hz}, \mathrm{CH}_{2} \mathrm{PNP}\right), 31.51\left(\mathrm{CH}_{3} t \mathrm{Bu}\right), 30.72\left(\mathrm{t}, J_{\mathrm{CP}}=8.2 \mathrm{~Hz}\right.$, $\left.\mathrm{CH}_{2} \mathrm{PNP}\right), 27.36\left(\mathrm{t},{ }^{1} J_{\mathrm{CP}}=10.2 \mathrm{~Hz}, \mathrm{CH} i \mathrm{Pr}\right), 24.80\left(\mathrm{t},{ }^{1} J_{\mathrm{CP}}=10.9\right.$ $\mathrm{Hz}, \mathrm{CH} i \mathrm{Pr}), 21.63\left(\mathrm{t},{ }^{2} J_{\mathrm{CP}}=2.9 \mathrm{~Hz}, \mathrm{CH}_{3} i \mathrm{Pr}\right), 21.09\left(\mathrm{t},{ }^{2} J_{\mathrm{CP}}=4.3\right.$ $\left.\mathrm{Hz}, \mathrm{CH}_{3} i \mathrm{Pr}\right), 19.28\left(\mathrm{CH}_{3} i \mathrm{Pr}\right), 17.87\left(\mathrm{CH}_{3} i \mathrm{Pr}\right) .2 \mathrm{D}\left\{{ }^{15} \mathrm{~N}-{ }^{1} \mathrm{H}\right\}$ HSQC NMR (298 K, C7D8, $40.565 \mathrm{MHz}, \mathrm{ppm}): \delta 54.0(\mathrm{NH}) .2 \mathrm{D}$ $\left\{{ }^{15} \mathrm{~N}-{ }^{1} \mathrm{H}\right\}$ HMBC NMR $\left(298 \mathrm{~K}, \mathrm{C}_{7} \mathrm{D}_{8}, 40.565 \mathrm{MHz}, \mathrm{ppm}\right): \delta 184.23$ $(\mathrm{CN}-t \mathrm{Bu})$.

Characterization of $\left[\mathrm{Ru}(\mathrm{H})_{2}\left(\mathbf{C N}-\mathrm{CH}_{2} \mathbf{P h}\right)\left(\mathbf{P N P}^{\mathrm{H}}\right)\right](\mathbf{5 a})$. To the suspension of $1 \mathbf{a}(0.3 \mathrm{~g}, 0.51 \mathrm{mmol})$ in toluene $(10 \mathrm{~mL})$ was added a solution of $\mathrm{NaHBEt}_{3}$ in toluene (1M, 2.1 equiv., $1.06 \mathrm{mmol}$ ) at $18^{\circ} \mathrm{C}$. The reaction mixture was stirred at room temperature. After $14 \mathrm{~h}$, the yellow solution was filtered throughout a celite column and evaporated under vacuum to afford a yellow solid. Attempts to purify the product were unsuccessful due to its low stability. Selected characterization elements: ${ }^{1} \mathrm{H}$ NMR $\left(300 \mathrm{~K}, \mathrm{C}_{6} \mathrm{D}_{6}\right.$, $300.129 \mathrm{MHz}, \mathrm{ppm}): \delta 4.45\left(\mathrm{~s}, 2 \mathrm{H}, \mathrm{CH}_{2} \mathrm{Ph}\right),-6.25\left(\mathrm{td},{ }^{2} J_{\mathrm{HH}}=6.8\right.$ $\left.\mathrm{Hz},{ }^{2} J_{\mathrm{HP}}=18.4 \mathrm{~Hz}, 1 \mathrm{H}, \mathrm{Ru}-\mathrm{H}\right),-6.48\left(\mathrm{td},{ }^{2} J_{\mathrm{HH}}=6.9 \mathrm{~Hz},{ }^{2} J_{\mathrm{HP}}=19\right.$ $\mathrm{Hz}, 1 \mathrm{H}, \mathrm{Ru}-\mathrm{H}) .{ }^{31} \mathrm{P}\left\{{ }^{1} \mathrm{H}\right\}$ NMR $\left(300 \mathrm{~K}, \mathrm{C}_{6} \mathrm{D}_{6}, 121.495 \mathrm{MHz}, \mathrm{ppm}\right)$ : $\delta 86.89$ (PNP).

$\left[\mathbf{R u}(\mathbf{H})_{2}(\mathbf{C N}-t \mathbf{B u})\left(\mathbf{P N P}^{\mathbf{H}}\right)\right](\mathbf{5 c})$. To a suspension of $\mathbf{1 c}(0.34 \mathrm{~g}, 0.61$ $\mathrm{mmol})$ in toluene $(10 \mathrm{~mL})$ was slowly added a solution of $\mathrm{NaHBEt}_{3}$ in toluene $(2.1$ equiv., $1 \mathrm{M}, 1.28 \mathrm{mmol})$ at $-18^{\circ} \mathrm{C}$. The reaction mixture was stirred for $14 \mathrm{~h}$ at room temperature. The resulting yellow solution was filtered throughout a celite column. The obtained solution was concentrated under reduced pressure and $n$-pentane was poured.Slow crystallization at $-18^{\circ} \mathrm{C}$ afford $5 \mathrm{c}$. Yield: $0.185 \mathrm{~g}, 62 \%$. As described above, two fac/mer isomers were obtained in respective ratio of 1/1.5. No satisfactory results were obtained due to complexe decomposition. For $f a c$-isomer $f a c-5 c$ : Selected data: ${ }^{1} \mathrm{H}$
NMR (285 K, $\left.\mathrm{C}_{7} \mathrm{D}_{8}, 400.33 \mathrm{MHz}, \mathrm{ppm}\right): \delta 3.84$ (br, $\left.1 \mathrm{H}, \mathrm{NH}\right), 1.14$ (s, 9H, $\left.\mathrm{CH}_{3} \mathrm{CN}-t \mathrm{Bu}\right),-8.82(2 \mathrm{H}, \mathrm{m}, \mathrm{Ru}-\mathrm{H}) .{ }^{31} \mathrm{P}\left\{{ }^{1} \mathrm{H}\right\} \mathrm{NMR}(285 \mathrm{~K}$, $\left.\mathrm{C}_{7} \mathrm{D}_{8}, 121.495 \mathrm{MHz}, \mathrm{ppm}\right): \delta 74.08$ (PNP). $2 \mathrm{D}\left\{{ }^{15} \mathrm{~N}-{ }^{1} \mathrm{H}\right\}$ HSQC (285 K, C7 8 8, $40.565 \mathrm{MHz}, \mathrm{ppm}): \delta 19.45$ (PNP). 2D $\left\{{ }^{15} \mathrm{~N}-{ }^{1} \mathrm{H}\right\}$ HMBC $\left(255 \mathrm{~K}, \mathrm{C}_{7} \mathrm{D}_{8}, 40.565 \mathrm{MHz}, \mathrm{ppm}\right): \delta 178(\mathrm{CN}-t \mathrm{Bu})$. For mer-isomer $\boldsymbol{m e r - 5 c}$ : Selected data ${ }^{1} \mathrm{H}$ NMR $\left(285 \mathrm{~K}, \mathrm{C}_{7} \mathrm{D}_{8}, 400.33\right.$ $\mathrm{MHz}, \mathrm{ppm}$ ): $\delta 2.48$ (br, $1 \mathrm{H}, \mathrm{NH}), 1.16\left(\mathrm{~s}, 9 \mathrm{H}, \mathrm{CH}_{3} \mathrm{CN}-t \mathrm{Bu}\right),-6.86$ $\left(\mathrm{td},{ }^{2} J_{\mathrm{HH}}=4.9 \mathrm{~Hz},{ }^{2} J_{\mathrm{HP}}=18 \mathrm{~Hz}, 1 \mathrm{H}, \mathrm{Ru}-\mathrm{H}\right),-7.05\left(\mathrm{td}, 1 \mathrm{H}, J_{\mathrm{HH}}=\right.$ $\left.4.0 \mathrm{~Hz},{ }^{2} J_{\mathrm{HP}}=19 \mathrm{~Hz}, \mathrm{Ru}-\mathrm{H}\right) .{ }^{31} \mathrm{P}\left\{{ }^{1} \mathrm{H}\right\} \mathrm{NMR}\left(285 \mathrm{~K}, \mathrm{C}_{7} \mathrm{D}_{8}, 121.495\right.$ $\mathrm{MHz}, \mathrm{ppm}): \delta 84.78$ (s, PNP). $2 \mathrm{D}\left\{{ }^{15} \mathrm{~N}-{ }^{1} \mathrm{H}\right\} \mathrm{HSQC}\left(285 \mathrm{~K}, \mathrm{C}_{7} \mathrm{D}_{8}\right.$, $40.565 \mathrm{MHz}, \mathrm{ppm}): \delta 31.0$ (PNP). $2 \mathrm{D}\left\{{ }^{15} \mathrm{~N}-{ }^{1} \mathrm{H}\right\} \mathrm{HMBC}(255 \mathrm{~K}$, $\left.\mathrm{C}_{7} \mathrm{D}_{8}, 40.565 \mathrm{MHz}, \mathrm{ppm}\right): \delta 184.6(\mathrm{CN}-t \mathrm{Bu})$. Isomeric mixture ${ }^{13} \mathrm{C}\left\{{ }^{1} \mathrm{H}\right\}$ NMR $\left(285 \mathrm{~K}, \mathrm{C}_{7} \mathrm{D}_{8}, 100.663 \mathrm{MHz}, \mathrm{ppm}\right): \delta 54.12\left(\mathrm{CH}_{2}\right.$ PNP), $52.35\left(\mathrm{CH}_{2} \mathrm{PNP}\right), 32.90(\mathrm{CH} i \mathrm{Pr}), 31.70\left(\mathrm{CH}_{3} \mathrm{CN}-t \mathrm{Bu}\right)$, $31.59\left(\mathrm{CH}_{3} \mathrm{CN}-t \mathrm{Bu}\right), 30.48(\mathrm{CH} i \mathrm{Pr}), 28.42\left(\mathrm{CH}_{2} \mathrm{PNP}\right), 27.13$ ( $\left.\mathrm{CH}_{2} \mathrm{PNP}\right), 27.11$ (CH $\left.i \mathrm{Pr}\right), 26.43(\mathrm{CH} i \mathrm{Pr}), 22.33\left(\mathrm{CH}_{3} i \mathrm{Pr}\right), 20.46$ $\left(\mathrm{CH}_{3} i \mathrm{Pr}\right), 20.01\left(\mathrm{CH}_{3} i \mathrm{Pr}\right), 19.99\left(\mathrm{CH}_{3} i \mathrm{Pr}\right), 18.3\left(\mathrm{CH}_{3} i \mathrm{Pr}\right)$.

[Ru(H)(CN-tBu)(PNP')] (6). To a solution of 4c (30 mg, 0.057 $\mathrm{mmol})$ in deuterated benzene $(1 \mathrm{~mL})$ was added $t \mathrm{BuOK}(1.02$ eq., $0.058 \mathrm{mmol})$ at ${ }^{\circ} 0 \mathrm{C}$. After stirring for $14 \mathrm{~h}$ at $\mathrm{RT}$, the yellow reaction mixture was filtered and analyzed by NMR. Selected characterization data: ${ }^{1} \mathrm{H}$ NMR $\left(300 \mathrm{~K}, \mathrm{C}_{6} \mathrm{D}_{6}, 300.129 \mathrm{MHz}, \mathrm{ppm}\right): \delta$ $18.74\left(\mathrm{t}, 1 \mathrm{H},{ }^{2} J_{\mathrm{HP}}=16.5 \mathrm{~Hz}, \mathrm{Ru}-\mathrm{H}\right) .{ }^{31} \mathrm{P}\left\{{ }^{1} \mathrm{H}\right\} \mathrm{NMR}\left(300 \mathrm{~K}, \mathrm{C}_{6} \mathrm{D}_{6}\right.$, 121.495 MHz, ppm): $\delta 91.78$ (PNP).

$\left.\left[\mathbf{R u}(\mathrm{H})\left(\mathbf{C N}-\mathrm{CH}_{2} \mathbf{P h}\right)_{2}(\mathbf{P N P})^{\mathrm{H}}\right)\right] \mathbf{C l}(\mathbf{7})$. To a solution of $\mathbf{1 a}(0.15 \mathrm{~g}$, $0.268 \mathrm{mmol})$ in toluene $(6 \mathrm{~mL})$ was slowly added a solution of benzylisocyanide ( 2.2 equiv., $69 \mathrm{mg}$ ) in toluene $(1 \mathrm{~mL})$ at RT. After stirring at RT for $24 \mathrm{~h}$, the resulting solution was evaporated to dryness under reduced pressure. The product was washed with $n$-pentane $(3 \times 3 \mathrm{~mL})$. The product can be also purified by slow crystallization into toluene $/ n$-pentane mixture at $-18^{\circ} \mathrm{C}$. After a few days, the white crystals were collected and washed with n-pentane (5mLx3) and finally dried under vacuum. Yield: $0.12 \mathrm{~g}, 67 \%$. Anal. Calcd. for $\mathrm{C}_{32} \mathrm{H}_{52} \mathrm{ClN}_{3} \mathrm{P}_{2} \mathrm{Ru}$ : C 56.75; H 7.74; N 6.21. Found: 57.03, H 8.01, N 5.98. FT-IR (v, $\left.\mathrm{cm}^{-1}\right): 3055$ (s, vNH), 2135.2 (vs), 2059.3 (vs, $v_{\mathrm{C} \equiv \mathrm{N}}$ ), 1816 (m, v $\left.v_{\mathrm{Ru}-\mathrm{H}}\right) .{ }^{1} \mathrm{H}$ NMR $\left(293 \mathrm{~K}, \mathrm{C}_{6} \mathrm{D}_{6}, 400.33\right.$ $\mathrm{MHz}, \mathrm{ppm}): \delta 8.43\left(\mathrm{br} \mathrm{t},{ }^{3} J_{\mathrm{HN}}=10.2 \mathrm{~Hz}, 1 \mathrm{H}, \mathrm{NH}\right), 7.78\left(\mathrm{~d},{ }^{3} J_{\mathrm{HH}}=\right.$ 7.7 Hz, $2 \mathrm{H}$, ortho- $\left.\mathrm{C}_{\mathrm{Ar}}-\mathrm{H}\right), 7.20-7.12\left(\mathrm{~m}, 2 \mathrm{H}, \mathrm{C}_{\mathrm{Ar}}-\mathrm{H}\right), 7.12-7.01(\mathrm{~m}$, $\left.4 \mathrm{H}, \mathrm{C}_{\mathrm{Ar}}-\mathrm{H}\right), 7.0-6.96\left(\mathrm{~m}, 2 \mathrm{H}, \mathrm{C}_{\mathrm{Ar}}-\mathrm{H}\right), 5.31\left(\mathrm{~s}, 2 \mathrm{H}, \mathrm{CH}_{2} \mathrm{Ph}\right), 4.05(\mathrm{~s}$, $2 \mathrm{H}, \mathrm{CH}_{2} \mathrm{Ph}$ ), 3.35 (m, 2H, $\left.\mathrm{CH}_{2} \mathrm{PNP}\right), 2.31$ (m, 2H, $\left.\mathrm{CH}_{2} \mathrm{PNP}\right), 1.97$ $(\mathrm{m}, 2 \mathrm{H}, \mathrm{CH} i \mathrm{Pr}), 1.85(\mathrm{~m}, 2 \mathrm{H}, \mathrm{CH} i \mathrm{Pr}), 1.79-1.67\left(\mathrm{~m}, 4 \mathrm{H}, \mathrm{CH}_{2}\right.$ PNP), $1.21\left(\mathrm{dt}, 6 \mathrm{H},{ }^{3} \mathrm{JHH}_{\mathrm{HH}}=7.4 \mathrm{~Hz},{ }^{3} J_{\mathrm{HP}}=7.5 \mathrm{~Hz}, \mathrm{CH}_{3} i \mathrm{Pr}\right), 1.02(\mathrm{~m}$, $\left.6 \mathrm{H}, \mathrm{CH}_{3} i \mathrm{Pr}\right), 1.01\left(\mathrm{~m}, 6 \mathrm{H}, \mathrm{CH}_{3} i \mathrm{Pr}\right), 0.98\left(\mathrm{~m}, 6 \mathrm{H}, \mathrm{CH}_{3} i \operatorname{Pr}\right)-8.48$ $\left(\mathrm{t},{ }^{2} J_{\mathrm{HP}}=18.9 \mathrm{~Hz}, 1 \mathrm{H}, \mathrm{Ru}-\mathrm{H}\right) .{ }^{31} \mathrm{P}\left\{{ }^{1} \mathrm{H}\right\}$ NMR $\left(298 \mathrm{~K}, \mathrm{C}_{6} \mathrm{D}_{6}, 121.495\right.$ $\mathrm{MHz}, \mathrm{ppm}): \delta 78.86$ (PNP). ${ }^{13} \mathrm{C}\left\{{ }^{1} \mathrm{H}\right\}$ NMR $\left(298 \mathrm{~K}, \mathrm{C}_{6} \mathrm{D}_{6}, 100.663\right.$ $\mathrm{MHz}, \mathrm{ppm}): \delta 171.38\left(\mathrm{t},{ }^{2} J_{\mathrm{CP}}=11.0 \mathrm{~Hz}, \mathrm{CNCH}_{2} \mathrm{Ph}\right), 157.42\left(\mathrm{t},{ }^{2} J_{\mathrm{CP}}\right.$ $\left.=8.4 \mathrm{~Hz}, C \mathrm{NCH}_{2} \mathrm{Ph}\right), 135.50,135.29\left(\mathrm{CH}_{2} C_{\mathrm{Ar}}\right), 129.67,129.34$, $128.75,127.95,127.07,125.70\left(\mathrm{C}_{\mathrm{Ar}}-\mathrm{H}, \mathrm{Ph}\right), 55.22\left(\mathrm{t}, J_{\mathrm{CP}}=3.7 \mathrm{~Hz}\right.$, $\left.\mathrm{CH}_{2} \mathrm{PNP}\right), 49.42,47.78\left(\mathrm{CH}_{2} \mathrm{Ph}\right), 31.02\left(\mathrm{t},{ }^{1} J_{\mathrm{CP}}=11.4 \mathrm{~Hz}, \mathrm{CH} i \mathrm{Pr}\right)$, $30.81\left(\mathrm{t}, J_{\mathrm{CP}}=10.4 \mathrm{~Hz}, \mathrm{CH}_{2} \mathrm{PNP}\right), 24.63\left(\mathrm{t},{ }^{1} J_{\mathrm{CP}}=12.3 \mathrm{~Hz}, \mathrm{CH}\right.$ $i \mathrm{Pr}), 20.53\left(\mathrm{t},{ }^{2} J_{\mathrm{CP}}=2.5 \mathrm{~Hz}, \mathrm{CH}_{3} i \mathrm{Pr}\right), 18.79\left(\mathrm{t},{ }^{2} J_{\mathrm{CP}}=1.5 \mathrm{~Hz}, \mathrm{CH}_{3}\right.$ $i \operatorname{Pr}), 18.27\left(\mathrm{CH}_{3} i \operatorname{Pr}\right) .2 \mathrm{D}\left\{{ }^{15} \mathrm{~N}-{ }^{1} \mathrm{H}\right\}$ HSQC NMR $\left(293 \mathrm{~K}, \mathrm{C}_{6} \mathrm{D}_{6}\right.$, $40.565 \mathrm{MHz}, \mathrm{ppm}): \delta 35.3(\mathrm{NH}) .2 \mathrm{D}\left\{{ }^{15} \mathrm{~N}-{ }^{1} \mathrm{H}\right\}$ HMBC NMR $(293$ $\left.\mathrm{K}, \mathrm{C}_{6} \mathrm{D}_{6}, 40.565 \mathrm{MHz}, \mathrm{ppm}\right): \delta 172.8,159.4\left(\mathrm{CNCH}_{2} \mathrm{Ph}\right)$.

$\left[\mathrm{Fe}(\mathrm{Br})\left(\mathrm{CN}-\mathrm{CH}_{2} \mathrm{Ph}\right)_{2}\left(\mathrm{PNP}^{\mathrm{H}}\right)\right] \mathrm{Br}(\mathbf{8})$. To a white suspension of $\left[\mathrm{FeBr}_{2}\left(\mathrm{PNP}^{\mathrm{H}}\right)\right](0.5 \mathrm{~g}, 0.96 \mathrm{mmol})$ in toluene $(30 \mathrm{~mL})$ was added dropwise a solution of benzyl isocyanide (3.0 equiv., $2.88 \mathrm{mmol}$, $0.337 \mathrm{~g})$ in toluene $(10 \mathrm{~mL})$ at room temperature. The reaction mixture immediately turned out to green. After stirring for $20 \mathrm{~h}$ at RT, the green-lemon solution was concentrated under reduced pressure and $n$-pentane $(30 \mathrm{~mL})$ was added. After overnight storage at -20 ${ }^{\circ} \mathrm{C}$, a green precipitate was obtained, washed with $n$-pentane $(4 \mathrm{x}$ $20 \mathrm{~mL}$ ) and dried under vacuum. Yield: $0.59 \mathrm{~g}, 82 \%$. Anal. Calcd. for $\mathrm{C}_{32} \mathrm{H}_{51} \mathrm{Br}_{2} \mathrm{~N}_{3} \mathrm{P}_{2} \mathrm{Fe}$ : C 50.88; $\mathrm{H}$ 6.81; N 5.56. Found: C 50.98, $\mathrm{H}$ 6.91, N 5.23. FT-IR $\left(\mathrm{cm}^{-1}\right): 3060.9\left(\mathrm{~m}, v_{\mathrm{NH}}\right), 2148.6,2114.2(\mathrm{~s}$, $\left.v_{\mathrm{C} \equiv \mathrm{N}}\right)$. Major isomer (cis-8/trans-8 ratio: $\left.15.6 / 1\right)$ : ${ }^{1} \mathrm{H}$ NMR $(293 \mathrm{~K}$, 
$\left.\mathrm{CD}_{2} \mathrm{Cl}_{2}, 800.13 \mathrm{MHz}, \mathrm{ppm}\right): \delta 7.49\left(\mathrm{~m}, 2 \mathrm{H}, \mathrm{C}_{\mathrm{Ar}}-\mathrm{H}\right), 7.4-7.33(\mathrm{~m}$, $\left.6 \mathrm{H}, \mathrm{C}_{\mathrm{Ar}}-\mathrm{H}\right), 7.30\left(\mathrm{~m}, 2 \mathrm{H}, \mathrm{C}_{\mathrm{Ar}}-\mathrm{H}\right), 6.51\left(\mathrm{br} \mathrm{t},{ }^{3} \mathrm{~J}_{\mathrm{HH}}=11.1 \mathrm{~Hz}, 1 \mathrm{H}\right.$, $\mathrm{NH}), 5.06\left(\mathrm{~s}, 2 \mathrm{H}, \mathrm{CNCH}_{2} \mathrm{Ph}\right), 4.80\left(\mathrm{~s}, 2 \mathrm{H}, \mathrm{CNCH}_{2} \mathrm{Ph}\right), 3.04(\mathrm{~m}$, 2H, $\mathrm{CH}_{2} \mathrm{PNP}$ ), 2.99 (m, 2H, CH $i \mathrm{Pr}$ ), 2.76 (m, 2H, $\left.\mathrm{CH}_{2} \mathrm{PNP}\right), 2.26$ (m, 2H, $\left.\mathrm{CH}_{2} \mathrm{PNP}\right), 2.17$ (m, $\mathrm{CH}_{2} \mathrm{PNP}$ ), 2.14 (m, 2H, $\left.\mathrm{CH} i \mathrm{Pr}\right), 1.37$ $\left(\mathrm{m}, 6 \mathrm{H}, \mathrm{CH}_{3} i \mathrm{Pr}\right), 1.36\left(\mathrm{~m}, 6 \mathrm{H}, \mathrm{CH}_{3} i \mathrm{Pr}\right), 1.18\left(\mathrm{td},{ }^{3} J_{\mathrm{HH}}=7.2 \mathrm{~Hz}\right.$, $\left.{ }^{3} J_{\mathrm{HP}}=7.0 \mathrm{~Hz}, 6 \mathrm{H}, \mathrm{CH}_{3} i \mathrm{Pr}\right), 1.05\left(\mathrm{td}, 6 \mathrm{H},{ }^{3} J_{\mathrm{HH}}=7.4 \mathrm{~Hz},{ }^{3} J_{\mathrm{HP}}=7.5\right.$ $\left.\mathrm{Hz}, \mathrm{CH}_{3} i \mathrm{Pr}\right) .{ }^{13} \mathrm{C}\left\{{ }^{1} \mathrm{H}\right\} \mathrm{NMR}\left(298 \mathrm{~K}, \mathrm{CD}_{2} \mathrm{Cl}_{2}, 100.663 \mathrm{MHz}, \mathrm{ppm}\right)$ : $\delta$ 171.1, $166.2\left(\mathrm{CNCH}_{2} \mathrm{Ph}\right), 133.44,133.19\left(\mathrm{CH}_{2} \mathrm{C}_{\mathrm{Ar}}\right), 129.32$, 129.23, 127.9 $\left(\mathrm{C}_{\mathrm{Ar}}-\mathrm{H}\right), 51.2,49.6\left(\mathrm{CNCH}_{2} \mathrm{Ph}\right), 49.6\left(\mathrm{CH}_{2} \mathrm{PNP}\right)$, $29.44\left(\mathrm{t},{ }^{1} J_{\mathrm{CP}}=11 \mathrm{~Hz}, \mathrm{CH} i \mathrm{Pr}\right), 27.67\left(\mathrm{t}, J_{\mathrm{CP}}=8.3 \mathrm{~Hz}, \mathrm{CH}_{2} \mathrm{PNP}\right)$, $24.67\left(\mathrm{t},{ }^{1} J_{\mathrm{CP}}=8.4 \mathrm{~Hz}, \mathrm{CH} i \mathrm{Pr}\right), 20.01,19.73,19.65,19.38\left(\mathrm{CH}_{3}\right.$ $i$ Pr). ${ }^{31} \mathrm{P}\left\{{ }^{1} \mathrm{H}\right\}$ NMR $\left(298 \mathrm{~K}, \mathrm{CD}_{2} \mathrm{Cl}_{2}, 121.495 \mathrm{MHz}, \mathrm{ppm}\right): \delta 72.0$ (PNP). 2D $\left\{{ }^{15} \mathrm{~N}-{ }^{1} \mathrm{H}\right\}$ HSQC NMR $\left(298 \mathrm{~K}, \mathrm{CD}_{2} \mathrm{Cl}_{2}, 40.565 \mathrm{MHz}\right.$, ppm): $\delta 30.2(\mathrm{NH}) .2 \mathrm{D}\left\{{ }^{15} \mathrm{~N}-{ }^{1} \mathrm{H}\right\}$ HMBC NMR $\left(298 \mathrm{~K}, \mathrm{CD}_{2} \mathrm{Cl}_{2}\right.$, $40.565 \mathrm{MHz}, \mathrm{ppm}): \delta 188.7,183.5\left(\mathrm{CNCH}_{2} \mathrm{Ph}\right)$. Minor isomer trans-8: ${ }^{1} \mathrm{H}$ NMR $\left(298 \mathrm{~K}, \mathrm{CD}_{2} \mathrm{Cl}_{2}, 800.13 \mathrm{MHz}, \mathrm{ppm}\right): \delta 7.76(\mathrm{~m}$, $\left.2 \mathrm{H}, \mathrm{C}_{\mathrm{Ar}}-\mathrm{H}\right), 7.48\left(\mathrm{~m}, 2 \mathrm{H}, \mathrm{C}_{\mathrm{Ar}}-\mathrm{H}\right), 7.45-7.33\left(\mathrm{~m}, 6 \mathrm{H}, \mathrm{C}_{\mathrm{Ar}}-\mathrm{H}\right), 5.44$, $5.16\left(\mathrm{~s}, 2 \mathrm{H}, \mathrm{CNCH}_{2} \mathrm{Ph}\right), 4.02\left(\mathrm{brt},{ }^{3} J_{\mathrm{HH}}=11.4 \mathrm{~Hz}, 1 \mathrm{H}, \mathrm{NH}, \mathrm{PNP}\right)$, 2.69, 2.60 (m, 2H, CH $i \mathrm{Pr}), 2.76\left(\mathrm{~m}, 2 \mathrm{H}, \mathrm{CH}_{2} \mathrm{PNP}\right), 2.43(\mathrm{~m}, 2 \mathrm{H}$, $\mathrm{CH}_{2} \mathrm{PNP}$ ), 1.97 (m, 2H, $\left.\mathrm{CH}_{2} \mathrm{PNP}\right), 1.69$ (m, 2H, $\left.\mathrm{CH}_{2} \mathrm{PNP}\right), 1.44$, 1.35, 1.34 (m, 6H, $\left.\mathrm{CH}_{3} i \mathrm{Pr}\right), 1.30\left(\mathrm{~m}, 2 \mathrm{H}, \mathrm{CH}_{2} \mathrm{PNP}\right), 1.22(\mathrm{~m}, 6 \mathrm{H}$, $\left.\mathrm{CH}_{3} i \mathrm{Pr}\right) .{ }^{13} \mathrm{C}\left\{{ }^{1} \mathrm{H}\right\}$ NMR $\left(298 \mathrm{~K}, \mathrm{CD}_{2} \mathrm{Cl}_{2}, 100.663 \mathrm{MHz}, \mathrm{ppm}\right): \delta$ 174, $168\left(\mathrm{CNCH}_{2} \mathrm{Ph}\right), 133.3,133.1$ (C $\mathrm{C}_{\text {Ar }}$ quat. $), 129.3,128.2\left(\mathrm{C}_{\mathrm{Ar}}-\right.$ $\mathrm{H}), 52.9\left(\mathrm{CH}_{2} \mathrm{PNP}\right), 50.3,50.0\left(\mathrm{CNCH}_{2} \mathrm{Ph}\right), 29.4(\mathrm{CH} i \mathrm{Pr}), 27.6$ $\left(\mathrm{CH}_{2} \mathrm{PNP}\right), 24.7$ (t, $\left.\mathrm{CH} i \mathrm{Pr}\right), 20.5,20.0,19.8,19.7\left(\mathrm{CH}_{3} i \mathrm{Pr}\right)$. ${ }^{31} \mathrm{P}\left\{{ }^{1} \mathrm{H}\right\}$ NMR $\left(298 \mathrm{~K}, \mathrm{CD}_{2} \mathrm{Cl}_{2}, 121.495 \mathrm{MHz}, \mathrm{ppm}\right): \delta 58.0$ (PNP). $2 \mathrm{D}\left\{{ }^{15} \mathrm{~N}-{ }^{1} \mathrm{H}\right\}$ HMBC NMR $\left(298 \mathrm{~K}, \mathrm{CD}_{2} \mathrm{Cl}_{2}, 40.565 \mathrm{MHz}, \mathrm{ppm}\right): \delta$ $186.3,183.2\left(\mathrm{CNCH}_{2} \mathrm{Ph}\right)$.

$\left[\mathrm{Fe}(\mathrm{Br})\left(\mathrm{CN}-\mathrm{CH}_{2} \mathrm{Ph}\right)_{2}\left(\mathbf{P N P}^{\mathrm{H}}\right)\right]\left(\mathrm{BPh}_{4}\right)(\mathbf{9})$. To a lemon-green solution of $\left[\mathrm{Fe}(\mathrm{Br})\left(\mathrm{CN}-\mathrm{CH}_{2} \mathrm{Ph}\right)_{2}\left(\mathrm{PNP}^{\mathrm{H}}\right)\right] \mathrm{Br}(\mathbf{8})(0.31 \mathrm{~g}, 0.40 \mathrm{mmol})$ in toluene $(20 \mathrm{~mL})$ was added $\mathrm{NaBPh}_{4}$ in excess $(0.68 \mathrm{~g}, 5$ equiv., 2.0 $\mathrm{mmol}$ ) at room temperature. The reaction mixture was stirred at room temperature for $20 \mathrm{~h}$, and filtered throughout a celite column. The obtained solution was evaporated to dryness. The residual solid was dissolved in a minimum volume of $\mathrm{CH}_{2} \mathrm{Cl}_{2}(2 \mathrm{~mL})$ and $n$-pentane $(8 \mathrm{~mL})$ was poured. Slow crystallization at $-18^{\circ} \mathrm{C}$ afforded 9 . Yield: $0.21 \mathrm{~g}, 53 \%$. Crystals suitable for X-ray analysis were obtained similarly. FT-IR $\left(\mathrm{cm}^{-1}\right): 3227\left(\mathrm{~s}, \mathrm{v}_{\mathrm{NH}}\right), 2146(\mathrm{~s}), 2108(\mathrm{~s}$, $\left.v_{\mathrm{C} \equiv \mathrm{N}}\right) .{ }^{1} \mathrm{H}$ NMR $\left(300 \mathrm{~K}, \mathrm{CD}_{2} \mathrm{Cl}_{2}, 300.13 \mathrm{MHz}, \mathrm{ppm}\right): \delta 7.5-7.3$ $\left(14 \mathrm{H}, \mathrm{C}_{\mathrm{Ar}}-\mathrm{H}\right), 7.3-7.18\left(4 \mathrm{H}, \mathrm{C}_{\mathrm{Ar}}-\mathrm{H}\right), 7.03\left(\mathrm{t},{ }^{3} \mathrm{~J}_{\mathrm{HH}}=7.4 \mathrm{~Hz}, 8 \mathrm{H}, \mathrm{C}_{\mathrm{Ar}}-\right.$ $\mathrm{H}), 6.88\left(\mathrm{~m}, 4 \mathrm{H}, \mathrm{C}_{\mathrm{Ar}}-\mathrm{H}\right), 4.76,4.63\left(\mathrm{~s}, 2 \mathrm{H}, \mathrm{CNCH}_{2} \mathrm{Ph}\right), 2.99(\mathrm{~m}$, $2 \mathrm{H}, \mathrm{CH} i \mathrm{Pr}$ ), 2.78-2.53 (m, 4H, $\left.\mathrm{CH}_{2} \mathrm{PNP}\right), 2.40\left(\mathrm{t},{ }^{3} J_{\mathrm{HH}}=11.8 \mathrm{~Hz}\right.$, $1 \mathrm{H}, \mathrm{NH}), 2.2\left(\mathrm{~m}, 2 \mathrm{H}, \mathrm{CH}_{2} \mathrm{PNP}\right), 2.05$ (m, 2H, CH $\left.i \mathrm{Pr}\right), 1.37$ (dt, $\left.{ }^{3} J_{\mathrm{HH}}=7.3 \mathrm{~Hz},{ }^{3} J_{\mathrm{HP}}=7.3 \mathrm{~Hz}, 6 \mathrm{H}, \mathrm{CH}_{3}, i \mathrm{Pr}\right), 1.34\left(\mathrm{dt},{ }^{3} J_{\mathrm{HH}}=7.5 \mathrm{~Hz}\right.$, $\left.{ }^{3} J_{\mathrm{HP}}=7.5 \mathrm{~Hz}, 6 \mathrm{H}, \mathrm{CH}_{3} i \mathrm{Pr}\right), 1.27\left(\mathrm{~m}, 2 \mathrm{H}, \mathrm{CH}_{2} \mathrm{PNP}\right), 1.21\left(\mathrm{dt},{ }^{3} J_{\mathrm{HH}}\right.$ $\left.=6.8 \mathrm{~Hz},{ }^{3} J_{\mathrm{HP}}=6.1 \mathrm{~Hz}, 6 \mathrm{H}, \mathrm{CH}_{3} i \mathrm{Pr}\right), 1.09\left(\mathrm{dt},{ }^{3} J_{\mathrm{HH}}=7.4 \mathrm{~Hz},{ }^{3} J_{\mathrm{HP}}\right.$ $\left.=7.7 \mathrm{~Hz}, 6 \mathrm{H}, \mathrm{CH}_{3} i \mathrm{Pr}\right) .{ }^{13} \mathrm{C}\left\{{ }^{1} \mathrm{H}\right\} \mathrm{NMR}\left(298 \mathrm{~K}, \mathrm{CD}_{2} \mathrm{Cl}_{2}, 75.468\right.$ $\mathrm{MHz}, \mathrm{ppm}): \delta 164.52\left(\mathrm{q},{ }^{1} J_{\mathrm{CB}}=50.1 \mathrm{~Hz}, \mathrm{C}_{\mathrm{Ar}}\right.$ quart. $\left.\mathrm{BPh}_{4}\right), 136.58$ (s, $\left.\mathrm{C}_{\mathrm{Ar}}-\mathrm{H}\right), 132.54$ ( $\mathrm{C}_{\mathrm{Ar}}$ quat.), 130.06, 130.02, 129.66, 129.49, $128.59,128.34,126.16,122.31\left(\mathrm{CAr}_{\mathrm{Ar}} \mathrm{H}\right), 50.89,49.92\left(\mathrm{CN}^{\left.-\mathrm{CH}_{2}\right)}\right.$, $49.63\left(\mathrm{t}, J_{\mathrm{CP}}=3.2 \mathrm{~Hz}, \mathrm{CH}_{2} \mathrm{PNP}\right), 29.87\left(\mathrm{t},{ }^{1} J_{\mathrm{CP}}=11 \mathrm{~Hz}, \mathrm{CH} i \mathrm{Pr}\right.$ ), $28.23\left(\mathrm{t}, J_{\mathrm{CP}}=8.5 \mathrm{~Hz}, \mathrm{CH}_{2} \mathrm{PNP}\right), 25.00\left(\mathrm{t},{ }^{1} J_{\mathrm{CP}}=9.2 \mathrm{~Hz}, \mathrm{CH} i \mathrm{Pr}\right)$, $20.03,19.72,19.56,19.42\left(\mathrm{CH}_{3}, i \mathrm{Pr}\right)$.

$\left[\mathrm{Fe}(\mathrm{H})(\mathrm{CN}-\boldsymbol{t} \mathbf{B u})_{2}\left(\mathrm{PNP}^{\mathrm{H}}\right)\right]\left(\mathrm{BH}_{4}\right) \quad(\mathbf{1 0})$. To a suspension of $\left[\mathrm{FeBr}_{2}\left(\mathrm{PNP}^{\mathrm{H}}\right)\right](0.3 \mathrm{~g}, 0.58 \mathrm{mmol})$ in toluene $(30 \mathrm{~mL})$ was added a solution of $t$-butylisocyanide ( 3 equiv.; $1.73 \mathrm{mmol}, 0.144 \mathrm{~g}$ ) in toluene $(2 \mathrm{~mL})$ at room temperature. After stirring for $20 \mathrm{~h}$ and evacuation to dryness, ethanol $(30 \mathrm{~mL})$ was added, affording a yellow suspension. After cooling at $-18{ }^{\circ} \mathrm{C}$, a solution of excess $\mathrm{NaBH}_{4}$ (10 molar equiv.) in ethanol $(10 \mathrm{~mL})$. The reaction mixture was allowed to warm up to room temperature, stirred for $16 \mathrm{~h}$ then evaporated to dryness under reduced pressure. Extraction with toluene $(3 \times 5 \mathrm{~mL})$ was performed and the combined extracts were concentrated. Addition of $n$-pentane at $-18^{\circ} \mathrm{C}$ afforded a microcrystalline white solid. Yield: $0.154 \mathrm{~g}$, (49\%. Anal. Calcd. for $\mathrm{C}_{26} \mathrm{H}_{60} \mathrm{BFeN}_{3} \mathrm{P}_{2}$ :
C 57.47; H 11.13; N 7.73. Found: C 58.29; H 12.21; N 7.91. FT-IR $\left(\mathrm{cm}^{-1}\right): 3058.1(\mathrm{~s}, \mathrm{NH}), 2284,2210\left(\mathrm{w}, \mathrm{BH}_{4}\right), 2111.1(\mathrm{~s}), 2046.9$ (vs, CN). ${ }^{1} \mathrm{H}$ NMR $\left(293 \mathrm{~K}, \mathrm{C}_{6} \mathrm{D}_{6}, 400.33 \mathrm{MHz}, \mathrm{ppm}\right): \delta 6.29$ (br, $1 \mathrm{H}, \mathrm{NH}), 3.28$ (m, 2H, CH $2 \mathrm{PNP}$ ), 2.32 (m, 2H, CH $i \mathrm{PrP}), 2.09$ (m, $2 \mathrm{H}, \mathrm{CH}_{2} \mathrm{PNP}$ ), 2.02 (m, 2H, CH $i \operatorname{PrP}$ ), 1.60 (br m, 2H, $\mathrm{CH}_{2} \mathrm{PNP}$ ), $1.56\left(\mathrm{~s}, 9 \mathrm{H}, \mathrm{CH}_{3} t \mathrm{Bu}\right), 1.41$ (br m, 2H, CH $\left.2 \mathrm{PNP}\right), 1.33\left(\mathrm{td},{ }^{3} J_{\mathrm{HH}}=\right.$ $\left.7.4 \mathrm{~Hz},{ }^{3} J_{\mathrm{HP}}=7.3 \mathrm{~Hz}, 6 \mathrm{H}, \mathrm{CH}_{3} i \mathrm{PrP}\right), 1.15\left(\mathrm{td},{ }^{3} J_{\mathrm{HH}}=7.1 \mathrm{~Hz},{ }^{3} J_{\mathrm{HP}}\right.$ $\left.=6.9 \mathrm{~Hz}, \mathrm{CH}_{3} i \mathrm{Pr}\right), 1.04\left(\mathrm{~m}, J_{\mathrm{HH}}=7.0 \mathrm{~Hz}, J_{\mathrm{HP}}=6.8 \mathrm{~Hz}, 6 \mathrm{H}, \mathrm{CH}_{3}\right.$ $i \operatorname{Pr}), 1.02\left(\mathrm{~m},{ }^{3} J_{\mathrm{HH}}=7.1 \mathrm{~Hz},{ }^{3} J_{\mathrm{HP}}=6.7 \mathrm{~Hz}, \mathrm{CH}_{3} i \mathrm{Pr}\right), 0.88(\mathrm{~s}, 9 \mathrm{H}$, $\left.\mathrm{CH}_{3} t \mathrm{Bu}\right),-10.48\left(\mathrm{t},{ }^{1} J_{\mathrm{HP}}=50 \mathrm{~Hz}, 1 \mathrm{H}, \mathrm{Ru}\right]-\mathrm{H} .{ }^{13} \mathrm{C}\left\{{ }^{1} \mathrm{H}\right\} \mathrm{NMR}(298$ $\left.\mathrm{K}, \mathrm{CD}_{2} \mathrm{Cl}_{2}, 100.663 \mathrm{MHz}, \mathrm{ppm}\right): \delta 175.39,166.21(\mathrm{CN} t \mathrm{Bu}), 56.36$, $55.33(\mathrm{C}$ quat. $t \mathrm{Bu}), 54.28\left(\mathrm{t}, J_{\mathrm{CP}}=4.1 \mathrm{~Hz}, \mathrm{CH}_{2} \mathrm{PNP}\right), 31.63\left(\mathrm{t},{ }^{1} J_{\mathrm{CP}}\right.$ $=8.9 \mathrm{~Hz}, \mathrm{CH} i \mathrm{Pr}), 30.77,30.63\left(\mathrm{CH}_{3} t \mathrm{Bu}\right), 30.03\left(\mathrm{t}, J_{\mathrm{CP}}=9.4 \mathrm{~Hz}\right.$, $\left.\mathrm{CH}_{2} \mathrm{PNP}\right), 25.81\left(\mathrm{t},{ }^{1} J_{\mathrm{CP}}=12.5 \mathrm{~Hz}, \mathrm{CH} i \mathrm{Pr}\right), 20.73,19.07,18.78$ $\left(\mathrm{CH}_{3} i \mathrm{Pr}\right) .{ }^{31} \mathrm{P}\left\{{ }^{1} \mathrm{H}\right\}$ NMR $\left(298 \mathrm{~K}, \mathrm{C}_{6} \mathrm{D}_{6}, 121.495 \mathrm{MHz}, \mathrm{ppm}\right): \delta$ 100.01 (2P). 2D $\left\{{ }^{15} \mathrm{~N}-{ }^{1} \mathrm{H}\right\}$ HSQC NMR $\left(298 \mathrm{~K}, \mathrm{C}_{6} \mathrm{D}_{6}, 40.565\right.$ $\mathrm{MHz}, \mathrm{ppm}): \delta 31.67(\mathrm{NH}) .2 \mathrm{D}\left\{{ }^{15} \mathrm{~N}-{ }^{1} \mathrm{H}\right\}$ HMBC NMR $(298 \mathrm{~K}$, $\left.\mathrm{C}_{6} \mathrm{D}_{6}, 40.565 \mathrm{MHz}, \mathrm{ppm}\right): \delta 196.5,193.2(\mathrm{CN} t \mathrm{Bu}) .{ }^{11} \mathrm{~B}\left\{{ }^{1} \mathrm{H}\right\} \mathrm{NMR}$ (293 K, C6 6 6, $128.4418 \mathrm{MHz}, \mathrm{ppm}): \delta$-38.9 (BH4).

Catalytic tests. $\mathrm{TOF}_{0}$ determination: For acceptorless dehydrogenative coupling reactions of butanol, the initial turnover frequency $\left(\mathrm{TOF}_{0}\right)$ was determined by plotting turnover number as a function of time. $\mathrm{TOF}_{0}$ was calculated from the slope of the linear regression performed on the initial linear part of the plot. Typical procedure for acceptorless dehydrogenative coupling of 1-butanol conducted in Schlenk tubes: In an argon filled glove-box, the selected complex $(6.5 \mu \mathrm{mol} ; 60 \mathrm{ppm})$ was weighted in a Schlenk tube containing a stirring bar. After connection to a Schlenk line, 1-butanol $(10 \mathrm{~mL} ; 8.10 \mathrm{~g} ; 109 \mathrm{mmol})$ was added via a syringe under an argon stream. The Schlenk tube was then equipped with a condenser topped by an argon bubbler. The system was heated using an oil bath $\left(130^{\circ} \mathrm{C}\right)$ and stirred magnetically under an argon stream. Aliquots (ca. $0.1 \mathrm{~mL}$ ) were periodically sampled to monitor the reaction progress over time. Aliquots were diluted with $\mathrm{CDCl}_{3}$ and analyzed by ${ }^{1} \mathrm{H}$ NMR for determination of yield, turnover number and turnover frequency. Both analytical methods gave identical results.

X-ray Structure Determination. A single crystal of each compound was mounted under inert perfluoropolyether wax on a Mitegen MicroLoop ${ }^{\mathrm{TM}}$. Single-crystal X-rays measurements were performed at $100 \mathrm{~K}$ under $\mathrm{N}_{2}$ stream from a Cryostream 700 device (OxfordCryosystems). Data were collected using an Apex II CCD $4 \mathrm{~K}$ Bruker diffractometer $(\lambda=0.71073 \AA)$. The structures were solved using SHELXT ${ }^{35}$ and refined by least-squares procedures on $\mathrm{F}^{2}$ using SHELXL2014. ${ }^{36}$ All Hydrogen atoms were placed in theoretical positions and refined riding on their parent atoms except for the hydride $\mathrm{H}$ attached to the $\mathrm{Ru}, \mathrm{B}$ and $\mathrm{N}$ atoms which was located from difference Fourier maps and refined isotropically. ORTEP drawings were generated with ORTEP-3. ${ }^{37}$ Crystallographic data have been deposited at the Cambridge Crystallographic Data Centre as Supplementary Publication Nos. CCDC 2006531-2006538. Copies of the data can be obtained free of charge on application to the Director, CCDC, 12 Union Road, Cambridge CB2 1EZ, U.K. (fax, (+44) 1223- 336-033; e-mail, deposit@ccdc.cam.ac.uk).

\section{ASSOCIATED CONTENT}

\section{Supporting Information}

The Supporting Information is available free of charge via the Internet at http://pubs.acs.org.

NMR spectra and X-ray crystallographic data (CIF).

\section{AUTHOR INFORMATION}

\section{Corresponding Author}


E-mail: regis.gauvin@ chimieparistech.psl.eu.

\section{Notes}

The authors declare no competing financial interests.

\section{ACKNOWLEDGMENT}

This work was performed in partnership with the SAS PIVERT, within the frame of the French Institute for the Energy Transition (Institut pour la Transition Energétique (ITE) P.I.V.E.R.T. (www.institut-pivert.com) selected as an Investment for the Future ("Investissements d'Avenir"). This work was supported, as part of the Investments for the Future, by the French Government under the reference ANR-001-01. The authors also thank the CNRS and University of Lille for their financial support. 


\section{REFERENCES}

1. a) Khusnutdinova, J. R.; Milstein D. Metal-Ligand Cooperation. Angew. Chem. Int. Ed. 2015, 54, 12236 - 12273. b) Editors Ikariya, T.; Shibasaki, M. Topics in Organometallic Chemistry 37: Bifunctional Molecular Catalysis, Springer-Verlag: Berlin Heidelberg, 2011.

2. a) Corma, A.; Navas, J.; Sabater, M. J. Advances in One-Pot Synthesis through Borrowing Hydrogen Catalysis, Chem. Rev. 2018, 118, 1410-1459. b) Irrgang, T.; Kempe, R. 3d-Metal Catalyzed N- and C-Alkylation Reactions via Borrowing Hydrogen or Hydrogen Autotransfer. Chem. Rev. 2019, 119, 2524-2549. c) Kallmeier, F.; Kempe, R. Manganese Complexes for (De)Hydrogenation Catalysis: A Comparison to Cobalt and Iron Catalysts. Angew.Chem.Int. Ed. 2018, 57, 46-60.

3. Noyori, R.; Yamakawa, M.; Hashiguchi, S. Metal-Ligand Bifunctional Catalysis: A Nonclassical Mechanism for Asymmetric Hydrogen Transfer between Alcohols and Carbonyl Compounds. J. Org. Chem. 2001, 66, 7931-7944.

4. Gunanathan, C.; Milstein D. Bond Activation and Catalysis by Ruthenium Pincer Complexes. Chem. Rev. 2014, 114, 12024-12087.

5. a) Ed. Morales-Morales D. Pincer Compounds: Chemistry and Applications; Elsevier Inc. 2018. b) Eds. Morales-Morales, D., Jensen, C. M. The Chemistry of Pincer Compounds; Elsevier: Amsterdam, 2007. c) b) Werkmeister, S.; Neumann, J.; Junge, K.; Beller, M. Pincer-Type Complexes for Catalytic (De)Hydrogenation and Transfer (De)Hydrogenation Reactions: Recent Progress. Chem. Eur. J. 2015, 21, 12226-12250. c) Gunanathan, C.; Milstein, D. Metal-Ligand Cooperation by Aromatization-Dearomatization: A New Paradigm in Bond Activation and "Green" Catalysis. Acc. Chem. Res. 44 2011, 44, 588-602. d) Gunanathan, C.; Milstein, D. Applications of Acceptorless Dehydrogenation and Related Transformations in Chemical Synthesis. Science 2013, 341, $249-260$.

6. a) Nielsen, M.; Junge, H.; Kammer, A.; Beller, M. Towards a Green Process for Bulk-Scale Synthesis of Ethyl Acetate: Efficient Acceptorless Dehydrogenation of Ethanol. Angew. Chem. Int. Ed. 2012, 51, 5711-5713. b) Nielsen, M.; Kammer, A.; Junge, D.; Cozzula, H.; Gladiali, S. S.; Beller, M. Efficient Hydrogen Production from Alcohols under Mild Reaction Conditions. Angew. Chem. Int. Ed. 2011, 50, 9593-9597. c) Bertoli, M.; Choualeb, A.; Lough, A. J.; Moore, B.; Spasyuk, D.; Gusev, D. G. Osmium and Ruthenium Catalysts for Dehydrogenation of Alcohols. Organometallics 2011, 30, 3479-3482. d) Chakraborty, S.; Dai, H.; Bhattacharya, P.; Fairweather, N. T.; Gibson, M. S.; Krause, J. A.; Guan, H. Iron-Based Catalysts for the Hydrogenation of Esters to Alcohols. J. Am. Chem. Soc. 2014, 136, 78697872. e) Bonitatibus, P. J., Jr.; Chakraborty, S.; Doherty, M. D.; Siclovan, O.; Jones, W. D.;Soloveichik, G. L. Reversible catalytic dehydrogenation of alcohols for energy storage. Proc. Natt. Acad. Sci. U. S. A. 2015, 112, 1687-1692. (f) Bielinski, E. A.; Förster, M.; Zhang, Y.; Bernskoetter, W. H.; Hazari, N.; Holthausen, M. C. Base-Free Methanol Dehydrogenation Using a Pincer-Supported Iron Compound and Lewis Acid Co-catalyst. ACS Catal. 2015, 5, 2404-2415. (g) Chakraborty, S. Lagaditis, P. O.; Förster, M.; Bielinski, E. A.; Hazari, N.; Holthausen, M. C.; Jones, W. D.; Schneider, S. Well-Defined Iron Catalysts for the Acceptorless Reversible Dehydrogenation-Hydrogenation of Alcohols and Ketones. ACS Catal. 2014, 4, 3994-4003. Werkmeister, S.; Junge, K.; Wendt, B.; Alberico, E.; Jiao, H.; Baumann W.; Junge, H.; Gallou, F.; Beller, M. Hydrogenation of Esters to Alcohols with a Well - Defined Iron Complex. Angew. Chem. Int. Ed. 2014, 53, 8722 -8726.

7. a) Zhang, J.; Leitus, G.; Ben-David, Y.; Milstein, D. Facile Conversion of Alcohols into Esters and Dihydrogen Catalyzed by New Ruthenium Complexes. J. Am. Chem. Soc. 2005, 127, 10840-10841. b) Spasyuk, D.; Vicent, C.; Gusev, D. G. Chemoselective Hydrogenation of Carbonyl Compounds and Acceptorless Dehydrogenative Coupling of Alcohols. J. Am. Chem. Soc. 2015, 137, 3743-3746. c) Spasyuk, D.; Gusev, D. G. Acceptorless Dehydrogenative Coupling of Ethanol and Hydrogenation of Esters and Imines Organometallics 2012, 31, 5239-5242. d) Spasyuk, D.; Smith, S.; Gusev, D.G. From Esters to Alcohols and Back with Ruthenium and Osmium Catalysts. Angew. Chem. Int. Ed. 2012, 51, 2772-2775. e) Zhang, J.; Balaraman, E.; Leitus, G.; Milstein, D. Electron-Rich PNP-and PNN-Type Ruthenium(II) Hydrido Borohydride Pincer Complexes. Synthesis, Structure, and Catalytic Dehydrogenation of Alcohols and Hydrogenation of Esters. Organometallics 2011, 30, 5716-5724. f) Fogler, E.; Garg, J. A.; Hu, P.; Leitus, G.; Shimon, L. J. W. Milstein, D. System with Potential Dual Modes of Metal-Ligand Cooperation: Highly Catalytically Active Pyridine-Based PNNH-Ru Pincer Complexes. Chem. Eur. J. 2014, 20, 15727-15731. g) He, L.-P.; Chen, T.; Gong, D.; Lai, Z.; Huang, K.-W. Organometallics 2012, 31, 5208-5211. Hale, L. V. A.; Malakar, T.; Tseng, K-.N. T.; Zimmerman, P. M.; Paul, A.; Szymczak, N. K. ACS Catal. 2016, 6, 4799-4813. h) Cao, Z.; Qiao, H.; Zeng F. Design, Synthesis, and Application of NNN Pincer Ligands Possessing a Remote Hydroxyl Group for RutheniumCatalyzed Transfer Hydrogenation of Ketones. Organometallics 2019, 38, 797-804.

8. a) D. Spasyuk, S. Smith, D. G. Gusev, Replacing Phosphorus with Sulfur for the Efficient Hydrogenation of Esters. Angew. Chem. Int. Ed. 2013, 52, 2538-2542. b) Gargir, M.; Ben-David, Y.; Leitus, G.; Diskin-Posner, Y.; Shimon, L. J. W. Milstein, D. Organometallics 2012, 31, 6207-6214. c) Schörgenhumer, J.; Zimmermann, A.; Waser, M. SNS-Ligands for Ru-Catalyzed Homogeneous Hydrogenation and Dehydrogenation Reactions. Org. Process Res. Dev. 2018, 22, 862-870. d) Page, M. J.; Wagler, J.; Messerle, B. A. Pyridine-2,6-bis(thioether) (SNS) Complexes of Ruthenium as Catalysts for Transfer Hydrogenation. Organometallics 2010, 29, 3790-3798. e) Puylaert, P.; van Heck, R.; Fan, Y.; Spannenberg, A.; Baumann, W.; Beller, M.; Medlock, J.; Bonrath, W.; Lefort, L.; Hinze, S.; de Vries, J. G. Selective Hydrogenation of $\alpha, \beta$-Unsaturated Aldehydes and Ketones by Air-Stable Ruthenium NNS Complexes. Chem. Eur. J. 2017, 23, 8473-8481. (f) Stadler, B. M.; Puylaert, P.; Diekamp, J.; van Heck, R.; Fan, Y.; Spannenberg, A.; Hinze, S.; de Vries, J. G. Inexpensive Ruthenium NNSComplexes as Efficient Ester Hydrogenation Catalysts with High $C=O$ 'vs. C $=C$ C Selectivities. Adv. Synth. Catal. 2018, 360, 1151-1158. g) Luo, Q.; Dai, Z.; Cong, H.; Li, R.; Peng, T.; Zhang. J. Oxidant-free synthesis of benzimidazoles from alcohols and aromatic diamines catalysed by new Ru(II)-PNS(O) pincer complexes. Dalton Trans. 2017,46, 15012-15022. h) Dub, P. A.; Scott, B. L.; Gordon, J. C. Air-Stable NNS (ENENES) Ligands and Their Well-Defined Ruthenium and Iridium Complexes for Molecular Catalysis. Organometallics 2015, 34, 4464-4479.

9 a) Le, L.; Liu, J.; He, T.; Kim, D.; Lindley, E. J.; Cervarich, T. N.; Malek, J. C.; Pham, J.; Buck, M. R.; Chianese, A. R. Structure-Function Relationship in Ester Hydrogenation Catalyzed by Ruthenium CNN-Pincer Complexes. Organometallics 2018, 37, 3286-3297. b) He, X.; Li, Y.; Fu, H.; Zheng, X.; Chen, H.; Li, R.; Yu, X. Synthesis of Unsymmetrical N-Heterocyclic Carbene-Nitrogen-Phosphine Chelated Ruthenium(II) Complexes and Their Reactivity in Acceptorless Dehydrogenative Coupling of Alcohols to Esters. Organometallics, 2019, 38, 1750-1760. c) Filonenko, G. A.; Aguila, M. J. B.; Schulpen, E. N.; van Putten, R.; Wiecko, J.; Müller, C.; Lefort, L.; Hensen, E. J. M.; Pidko, E. A. Bis-Nheterocyclic carbene aminopincer ligands enable high activity in Ru-catalyzed ester hydrogenation. J. Am. Chem. Soc. 2015, 137, 7620-7623.

10. Alig, L.; Fritz, M.; Schneider, S. First-Row Transition Metal (De)Hydrogenation Catalysis Based On Functional Pincer Ligands. Chem. Rev. 2019, 119, 26812751.

11. Fogler, E.; Iron, M. A.; Zhang, J.; Ben-David, Y.; Diskin-Posner, Y.; Leitus, G.; Shimon, L. J. W. Milstein D. Ru(0) and Ru(II) Nitrosyl Pincer Complexes: Structure, Reactivity, and Catalytic Activity. Inorg. Chem. 2013, 52, 11469-11479.

12. Ogata, O.; Nakayama, Y.; Nara, H.; Fujiwhara, M.; Kayaki, Y. Atmospheric Hydrogenation of Esters Catalyzed by PNP-Ruthenium Complexes with an NHeterocyclic Carbene Ligand. Org. Lett. 2016, 18, 3894-3897.

13. Smith, N. E.; Bernskoetter, W. H.; Hazari, N.; Mercado, B. Q. Synthesis and Catalytic Activity of PNP-Supported Iron Complexes with Ancillary Isonitrile Ligands Organometallics, 2017, 36, 3995-4004; b) Curley, J. B.; Smith, N. E.; Bernskoetter, W. H.; Hazari, N.; Mercado, B. Q. Catalytic Formic Acid Dehydrogenation and $\mathrm{CO}_{2}$ Hydrogenation Using Iron PNRP Pincer Complexes with Isonitrile Ligands Organometallics 2018, 37, 21, 3846-3853.

${ }^{14}$ a) Naik, A. ; Maji, T. ; Reiser, O. ; Iron(ii)-bis(isonitrile) complexes: novel catalysts in asymmetric transfer hydrogenations of aromatic and heteroaromatic ketones, Chem. Commun., 2010,46, 4475-4477; b) Bigler, R.; Mezetti, A.; Isonitrile Iron(II) Complexes with Chiral $\mathrm{N}_{2} \mathrm{P}_{2}$ Macrocycles in the Enantioselective Transfer Hydrogenation of Ketones, Org. Lett. 2014, 16, 6460-6463; c) Bigler, R.; Huber, R.; Mezetti, A. Highly Enantioselective Transfer Hydrogenation of Ketones with Chiral $(\mathrm{NH})_{2} \mathrm{P}_{2}$ Macrocyclic Iron(II) Complexes, Angew. Chem. Int. Ed. 2015, 54, 1-5.

15. a) Boyarskiy, V. P.; Bokach, N. A.; Luzyanin, K. V.; Kukushkin, V. Y., Metal-Mediated and Metal-Catalyzed Reactions of Isocyanides, Chem. Rev. 2015, 115, 2698-2779; b) Mahmudov, K. T.; Kukushkin, V. Y.; Gurbanov, A. V.; Kinzhalov, M. A.; Boyarskiy, V. P.; Guedes da Silva, M. F. C.; Pombeiro, A. J.L. Isocyanide metal complexes in catalysis. Coord. Chem. Rev. 2019, 384, 65-89.

${ }^{16}$ a) Zhang, L.; Raffa, G.; Nguyen, D. H.; Swesi, Y.; Corbel-Demailly, L.; Capet, F.; Trivelli, X.; Desset, S.; Paul, S.; Paul, J. F.; Fongarland, P.; Dumeignil, F.; Gauvin, R. M. Acceptorless dehydrogenative coupling of alcohols catalysed by ruthenium PNP complexes: Influence of catalyst structure and of hydrogen mass transfer. J. Catal., 2016, 340, 331-343; b) Nguyen, D. H.; Raffa, G.; Morin, Y.; Desset, S.; Capet, F.; Nardello-Rataj, V.; Dumeignil, F.; Gauvin, R. M. Solvent- and Base-Free Synthesis of Wax Esters from Fatty Acid Methyl Esters by Consecutive One-Pot, Two-Step Catalysis. Green Chem. 2017, 19, 5665-5673; c) Nguyen, D. H.; Trivelli, X.; Capet, F.; Paul, J.-F.; Dumeignil, F.; Gauvin, R. M. Manganese Pincer Complexes for the Base-Free, Acceptorless Dehydrogenative Coupling of Alcohols to Esters: Development, Scope, and Understanding. ACS Catal. 2017, 7, 2022-2032; d) Nguyen, D. H.; Trivelli, X.; Capet, F.; Swesi, Y.; Favre-Réguillon, 
A.; Vanoye, L.; Dumeignil, F.; Gauvin, R. M. Deeper Mechanistic Insight into Ru Pincer-Mediated Acceptorless Dehydrogenative Coupling of Alcohols: Exchanges, Intermediates, and Deactivation Species, ACS Catal. 2018, 8, 4719-4734.

17. Käß, M.; Friedrich, A.; Drees, M.; Schneider S. Ruthenium Complexes with Cooperative PNP Ligands: Bifunctional Catalysts for the Dehydrogenation of Ammonia-Borane. Angew. Chem. Int. Ed. 2009, 48, 905-907.

18. Friedrich, A.; Drees, M.; Käss, M.; Herdtweck, E.; Schneider, S. Ruthenium Complexes with Cooperative PNP-Pincer Amine, Amido, Imine, and Enamido Ligands: Facile Ligand Backbone Functionalization Processes. Inorg. Chem. 2010, 49, 5482-5494.

19. Bianchini, C.; Masi, D.; Romerosa, A.; Zanobini, F.; Peruzzini M. Aminocarbene Complexes as Intermediates in the Ruthenium-Assisted Aminolysis of Phenylacetylene to Isonitriles and Toluene. Organometallics 1999, 18, 2376-2386.

20. Rahman, M. S.; Prince, P. D.; Steed, J. W.; Hii K. K. Coordination Chemistry and Catalytic Activity of Ruthenium Complexes of Terdentate Phosphorus-Nitrogen-Phosphorus (PNP) and Bidentate Phosphorus-Nitrogen (PNH) Ligands. Organometallics 2002, 21, 4927-4933.

${ }^{21}$ Rozenel, S. S.; Arnold, J. Bimetallic Ruthenium PNP Pincer Complex As a Platform to Model Proposed Intermediates in Dinitrogen Reduction to Ammonia. Inorg. Chem. 2012, 51, 9730-9739.

${ }^{22}{ }^{15}$ N NMR: a) Stephany, R. W. de Bie M. J. A ; Drenth W. A ${ }^{13}$ C-NMR and IR Study of Isocyanides and Some of Their Complexes. Organic Magnetic Resonance, 1974, 6, 45-47. b) Cmoch, P.; Głaszczka, R.; Jaźwiński, J.; Kamieńskia, B.; Senkara E. Adducts of nitrogenous ligands with rhodium (II) tetracarboxylates and tetraformamidinate: NMR spectroscopy and density functional theory calculations. Magn. Reson. Chem. 2014, 52, 61-68. c) Cmoch, P; Jaźwiński, J. NMR studies on interaction of rhodium(II) tetratrifluoroacetate with the ligands containing nitrile, isonitrile, isothiocyanate or isocyanate functional groups. J. Mol. Struct. 2009, 919, 348-355.

${ }^{23}$ Matsubara, K.; Mima, S.; Oda, T.; Nagashima, H. Preparation, structures, and haptotropic rearrangement of novel dinuclear ruthenium complexes, $\left(\mu^{2}, \eta^{3}: \eta^{5}-\right.$ guaiazulene $) \mathrm{Ru}_{2}(\mathrm{CO})_{4}(\mathrm{CNR})$. J. Organomet. Chem. 2002, 650, 96-107.

${ }^{24}$ Analysis of crystals by ${ }^{1} \mathrm{H}$ and ${ }^{11} \mathrm{~B}$ NMR shows the presence of $\mathrm{BEt}_{4}{ }^{-}:{ }^{1} \mathrm{H} \mathrm{NMR}\left(285 \mathrm{~K}, \mathrm{C}_{7} \mathrm{D}_{8}, 400.33 \mathrm{MHz}, \mathrm{ppm}\right): \delta ;{ }^{11} \mathrm{~B}\left\{{ }^{1} \mathrm{H}\right\} \mathrm{NMR}\left(285 \mathrm{~K}, \mathrm{C}_{7} \mathrm{D}_{8}, 128.4418 \mathrm{MHz}\right.$, $\mathrm{ppm}): \delta-16.14(\mathrm{~s}, 1 \mathrm{~B})$. The formation of [BEt $]^{-}$probably comes from the disproportionation reactions of $\mathrm{NaHEt}_{3}$ or the commercial [Na(HBEt 3 )] may contain signifi-

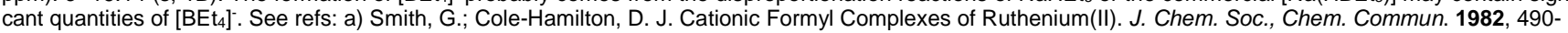

491. b) Smith, G.; Cole-Hamilton, D. J. The Preparation and Characterisation of Cationic Formyl Complexes of Ruthenium(II); Crystal and Molecular Structure of

the Complex trans- Bis[l,2- bis( diphenylphosphino(ethane-PP'] carbonyl(deuterioformyl)-ruthenium(II) Hexafluoroantimonate-Dichloromethane(1/1). J. Chem. Soc. Dalton Trans. 1983, 2501-2507.

${ }^{25}$ Jeffrey, G. A.; Saenger, W. Hydrogen Bonding in Biological Structures; Springer: Berlin, 1991.

${ }^{26}$ Kar, S.; Sen, R.; Kothandaraman, J.; Goeppert, A.; Chowdhury, R.; Munoz, S. B.; Haiges, R.; Prakash, R. G. S. Mechanistic Insights into Ruthenium-PincerCatalyzed Amine Assisted Homogeneous Hydrogenation of $\mathrm{CO}_{2}$ to Methanol. J. Am. Chem. Soc. 2019, 141, 3160-3170.

${ }^{27}$ Filonenko, G. A.; van Putten, R.; Hensen, E. J. M. ; Pidko, E. A. Catalytic (de)hydrogenation promoted by non-precious metals - Co, Fe and Mn: recent advances in an emerging field, Chem. Soc. Rev. 2018, 47, 1459-1483.

${ }^{28}$ The anion exchange reaction from the cis-8 and trans-8 mixture affords the related complexes cis-9 and trans-9, from which cis-9 can be obtained as pure compound from crystallization. Only cis-9-related data is reported here.

${ }^{29}$ Michelin, R. A.; Pombeiro, A. J. L.; Guedes da Silva, M. F. C. Aminocarbene complexes derived from nucleophilic addition to isocyanide ligands Coord. Chem. Rev., 2001, 218, 75-112.

${ }^{30}$ De Luca, L. ; Passera, A. ; Mezetti, A. Asymmetric Transfer Hydrogenation with a Bifunctional Iron(II) Hydride: Experiment Meets Computation, J. Am. Chem. Soc. 2019, 141, 2545-2556

${ }^{31}$ Naik, A.; Maji, T.; Reiser, O. Iron(II)-bis(isonitrile) complexes: novel catalysts in asymmetric transfer hydrogenations of aromatic and heteroaromatic ketones, Chem. Commun. 2010, 46, 4475-4477.

${ }^{32}$ Duckett, S. B.; Lowe, J. P.; Mawby, R. J. Use of the tetrahydroborate ligand as "gate-keeper" and protected hydride ligand: preparation and study of alkyl hydride and acyl hydride complexes of ruthenium(ii), Dalton Trans. 2006, 2661-2670.

${ }^{33}$ a) Tetrick, S. M.; Walton, R. A. Homoleptic Isocyanide Complexes of Ruthenium(II) and Osmium(II), Inorg. Chem. 1985, 24, 3363-3366; b) Jones, W. D.; Kosar, W. P. Preparation and C-N Cleavage Reactions of Bis[(dimethylphosphino)ethane]ruthenium Isocyanide Complexes, Organometallics 1986, 5, 1823-1829.

${ }^{34}$ Ma, W.; Cui, S.; Sun, H.; Tang, W.; Xue, D.; Li, C.; Fan, J.; Xiao, J.; Wang, C. Iron-Catalyzed Alkylation of Nitriles with Alcohols, Chem. Eur. J. 2018, 24, 1311813123.

35. Sheldrick, G. M. SHELXT - Integrated space-group and crystal-structure determination. Acta Crystallogr. Sect. A 2015, 71, 3-8.

36. Sheldrick, G. M. Crystal structure refinement with SHELXL. Acta Crystallogr Sect. C 2015, 71, 3-8.

37. Farrugia, L. J. ORTEP-3 for Windows - a version of ORTEP-III with a Graphical User Interface (GUI); J. Appl. Crystallogr. $1997,30,565$. 


\section{Table of Contents Graphic and Synopsis}

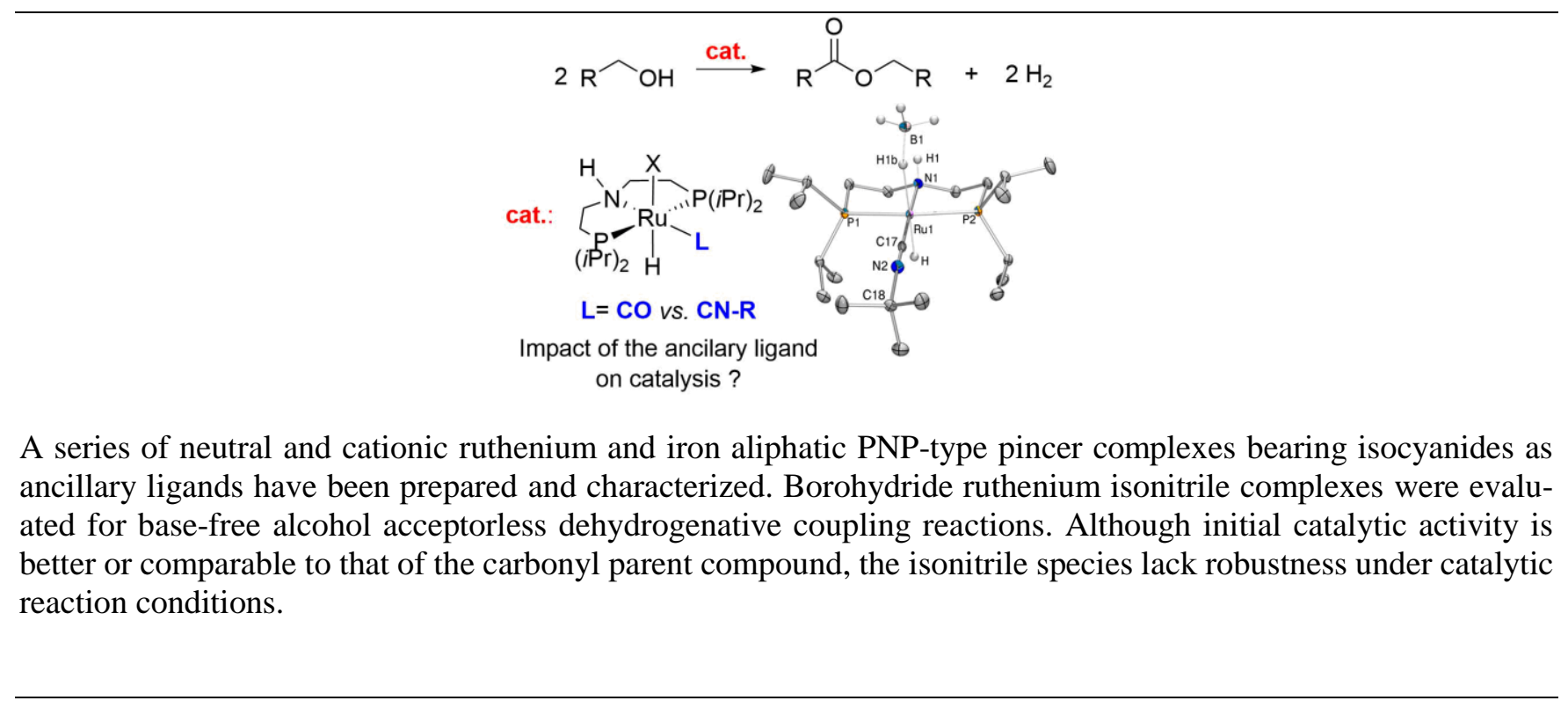

